\title{
Learning Through Movement
}

An elementary school designed for play.

\section{Andrea Leigh Swiatocha}

Thesis submitted to the faculty of the Virginia Polytechnic Institute and State University in partial fulfillment of the requirements for the degree of

Master of Architecture in

Architecture

Paul Emmons

Susan Piedmont-Palladino

Paul Kelsch

May 1, 2013

Alexandria, Virginia

Keywords: Learning, Movement, School, Active Design, Community 
ABSTRACT

\section{Learning Through Movement}

An Elementary School designed for play.

Andrea Leigh Swiatocha

Humans are designed to move. Movement is a key component of physical and mental maturation in children. It can take place in various settings, with different levels of intensity. During the developmental years of a child, it is imperative that a child is active. Most often movement and play are thought to occur outdoors. The idea of the "playground" activity does not have to be isolated to the outdoors. Children should be encouraged to be physically active in structured play, allowed free play with peers for social and emotiona development, as well as learn through hands-on experiments that are important for their cognitive development. Play is how children experience their world and create new discoveries about themselves and others.

This thesis will be explored through the design of an elementary school for Alexandria, VA. An elementary school creates the perfect setting for which these elements of movement and learning to combine. This thesis explores the way in which the movement of the outdoor school yard can occur within the school building. The school grounds serve as demonstration to the community for active learning. Incorporating active design through elevation changes, material changes and the transition between indoor and outdoor allow the school to be a model for "learning through movement." This school also begins to address the larger issues of our society's unhealthy lifestyle by designing three levels of active design for the community, building, and individual child. 


\section{Learning Through Movement}

An elementary school designed for play

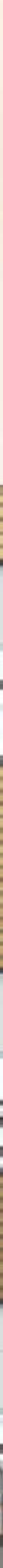

Andrea Leigh Swiatocha 


\section{LIST OF FIGURES}

All images property of author unless otherwise noted.

All images reproduced from other sources are used under fair use.

Permission for all photographs included was granted to author unless otherwise noted.

1.1 Children sit at desks for extended periods throughout the school day.

Free-play at sand-light table. Location: Pittsburgh Children's Museum

1.3 Decreasing a sedentary lifestyle through play and learning

$$
\text { Location: Pittsburgh Children's Museum }
$$

Chut Development ages 4-11)

1.5 Chutes and Ladders Motor Skills Adventure

2.1 A child enjoying a world of free play with Imagination Playground Rockwell Group. Location: National Building Museum (NBM)

2.2 Interactive digital display of Imagination Playground. Location: NBM

2.3 Children at play with Imagination Playground. Location: NBM

2.4 Children at play with Imagination Playground. Location: NBM

2.5 Children at recess. Location: Ashlawn Elementary

2.6 The 3 S's of the Playground: "THE SWING"

2.6 The 3 S's of the Playground: "THE SLIDE"

28 The 3 S's of the Playground: "THE SEESAW"

3.1 School grounds serve as public playgrounds. Location: Lyles Crouch Elementary

3.2 Walking to school. Location: Ashlawn Elementary

3.3 Map of existing City of Alexandria elementary schools.

3.4 Targeted area for future elementary school.

3.5 Historic District Boundaries

("Alexandria's African American History - Black Education and Parker-Gray

School" Page updated Apr 2, 2012 12:41 PM http://alexandriava.gov/

historic/blackhistory/default.aspx?id=37214\#parker. Accessed 10 Sept. 2012

Original Parker-Gray Elementary School

("Alexandria's African American History - Black Education and Parker-Gray School" Page updated Apr 2, 2012 12:41 PM http://alexandriava.gov/

historic/blackhistory/default.aspx?id=37214\#parker. Accessed 10 Sept. 2012)

3.7 Hallowell School for Girls

("Alexandria's African American History - Black Education and Parker-Gray

School" Page updated Apr 2, 2012 12:41 PM http://alexandriava.gov/

historic/blackhistory/default.aspx?id=3721 4\#parker. Accessed 10 Sept. 2012)

3.8 Active transportation Diagram

3.9 Proposed Active Community Diagram.

Students learning through hands-on experiments.

Location: Pittsburgh Children's Museum

Children at recess. Location: Ashlawn Elementary

Free-play at recess. Location: Ashlawn Elementary

Interactive digital display of Imagination Playground. Location: NBM

Roofs can provide additional open play fields.

Gymnasiums are critical for developing motor skills.

Openings between floors creates a sense of school community.

Digital and printed hallway displays for learning.

variation in stair rise and depth.

4.10 Hallway provides visibility to the outdoors.

\section{LIST OF FIGURES}

4.11 Platforms and elevation changes within the classroom.

4.12 Flexibility of classroom expansion

4.13 "Desk + Chair"

4.14 Swings within the classroom.

4.15 Outdoor learning through a network of climbing and net elements.

4.16 Organized and unstructured outdoor play.

4.17 Terraced amphitheater connected to the media center.

4.18 Gardens and plant growth provide children with hands-on learning.

5.1 Learning occurs both indoors and outdoors, even while playing hopscotch. (Permission to use this photograph of Liam was granted by his mother, Liz Bryan-Amick, on March 11, 2013)

5.2 Photo of Site+Building Model

5.3 Site Plan

5.4 Detail of Classroom window - North Elevation

5.5 North Elevation

5.6 Perspective of East Entry

$\mathbf{5 . 7}$ East Elevation

$\begin{array}{ll}\mathbf{5 . 7} & \text { East Elevation } \\ \mathbf{5 . 8} & \text { Section 1 - Main Entry through Courtyard }\end{array}$

5.8 Section 1 - Main Entry through Courtyard

$\mathbf{5 . 9}$ Detail of Classroom corridor ramps

$\mathbf{5 . 1 0}$ Section 2 - Classroom corridor

$\mathbf{5 . 1 1}$ Perspective of The Assem of Courtyard Level

$\mathbf{5 . 1 2}$ Plan of Courtyard Level

$\mathbf{5 . 1 3}$ Perspective of Cou
$\mathbf{5 . 1 4}$ Plan of Main Level

5.14 Plan of Main Level
5.15 Perspective of 3rd Floor Suspension Bridge

5.16 Plan of Upper Level

5.17 Detail of classroom teaching wall - Section 3

5.18 Section 3 - Classrooms to Gymnasium

5.19 Detail of Gymansium and Theater Stage - Section 4

5.20 Section 4 - Public Wing

5.21 Detail of public Health Center entrance - South Elevation

5.22 South Elevation

5.23 Vignette - Teaching Wall

$\mathbf{5 . 2 4}$ Vignette - Student Door

5.25 Vignette - Hopscotch Hallway

5.26 Plan of Classroom Extension

5.26 Plan of Classroom Extension

5.27 Vignette - Swing (Chair + Desk)

5.28 Vignette - Garage Door

5.29 Vignette - Reading Window

5.31 Shoto of Site+Building Model 


\section{LIST OF FIGURES}

\section{CASE STUDY - ASHLAWN ELEMENTARY, ARLINGTON COUNTY, VA}

\section{Source: personal}

6.1 Arrival by Car

6.2 Arrival by Bus

6.3 Arrival by Bike

6.4 Desk + Chair

6.5 Courtyard Hallway

6.6 Hallway lockers

83

CASE STUDY - CLAREMONT ELEMENTARY, ARLINGTON COUNTY, VA

\section{Source: personal}

6.7 Bus + Car Arrival

6.8 Main Entrance

6.9 Outdoor Classroom

6.10 Hallway Ramps

6.11 Hallway break-out space

CASE STUDY - LYLES-CROUCH TRADITIONAL ACADEMY, ALEXANDRIA, VA

\section{Source: personal}

6.12 Main Entrance

6.13 Garden

6.14 Outdoor Play

6.15 Outdoor Play

6.16 Open Play fields

CASE STUDY - JOHN ADAMS ELEMENTARY, ALEXANDRIA, VA

\section{Source: personal}

6.17 Main Entrance

Egress Stair

6.19 Natural landscape

6.20 Outdoor classroom

6.21 Material change

6.22 Outdoor classroom

\section{LIST OF FIGURES}

CASE STUDY - PLAY WORK BUILD (EXHIBIT) - IMAGINATION PLAYGROUND, WASHINGTON, DC

6.23-27 Children playing with Imagination Playground

CASE STUDY - CLIMBING WALL, CHILDREN'S MUSEUM OF PITTSBURGH, PA

Source: personal

6.28-32 Children climbing through wal

CASE STUDY - WALL-HOLLA, NETHERLANDS

Source: Design Boom. "Carve. wallholla" 21 Sept. 2006. http://www.designboom.com/

design/carve-wall-holla/ Images Courtesy: Milan Van der Storm. Accessed 14 Mar. 2013.

6.33-36 Children climbing

CASE STUDY - SCULPTURAL PLAYGROUND, WIESBADEN, GERMANY

Source: Arch Daily. "Sculptural Playground / ANNABAU" 04 Jun. 2011. http://www.

archdaily.com/139145/sculptural-playground-annabau/ Images Courtesy: Annabau.

Accessed 12 Oct. 2012

6.37-40 Outdoor adventure

CASE STUDY - MORRIS ARBORETUM'S TREE ADVENTURE, PHILADELPHIA, PA

Source: Arch Daily. "Morris Arboretum Tree Adventure / Metcalfe Architecture \& Design"

$14 \mathrm{Dec} .2010 \mathrm{http} / / / \mathrm{www}$.archdaily.com/95781/morris-arboretum-tree-adventure-metcalfe-

architecture-design/ Images Courtesy: Paul Warchol. Accessed 15 Oct. 2012

6.41-45 Tree Canopy adventure

CASE STUDY - AARHUS GYMNASTICS \& MOTOR SKILLS HALL, AARHUS, DENMARK

Source: Arch Daily. "Aarhus Gymnastics and Motor Skills Hall / C. F. Møller Architects" 20 Jun. 2010. http:// www. archdaily com/65069/aarhus-gymnastics-and-motor-skills-hall-c-f-m\%C3\%B8ller-architects/ Images Courtesy: Poul Nyholm, Julian Weye. Accessed 29 Oct. 2012

6.46-50 Children developing their fundamental motor skills 


\section{CONTENTS}

ABSTRACT

LIST OF FIGURES

1 MOVEMENT

Lack of Movement

Dual Crisis

Child Development

2 PLAY

Types of Play

Three S's of the Playground

3 ACTIVE COMMUNITY

Alexandria Public Schools

Site Selection

Active Transportation

Public Facilities

4 ACTIVE LEARNING

Building elements

5 ACTIVE CHILD

Parker-Gray Elementary School (Liam's School Day)

\section{APPENDICES}

Case Studies

$$
\text { a. school visits }
$$

b. sample projects

References 



\section{LACK OF MOVEMENT IS DETRIMENTAL}

\section{TO THE GROWTH AND DEVELOPMENT OF A}

\section{CHILD.}

Many factors have contributed to the reduction of movement and play for children including a hurried lifestyle, technology, changes in family structure, and increased attention to academics and enrichment activities at the expense of recess or free child-centered play. As these changes take place, it is important to retain the value of movement and play in child's daily life.

Figure 1.2
In a recent study, Caroline Fusco - Associate Professor of Kinesiology and Physical Education at the University of Toronto, looks at this idea of 'healthification' and how active urban spaces are imaged and controlled by the policy-makers in Ontario, Canada. Fusco evaluates the impact of space and health on the physical activity of youth in the city.

Growing concern for the "dual crisis" in obesity and sedentariness, has led to increased funding for research analyzing the impact of the environment on youth's active lifestyle. In Ontario, Canada, the government has responded to this research by demanding 'healthy spaces' in order to promote active lifestyles among the young (Fusco, 43)

HEALTHY, SAFE SPACE

With the space constraints common in an urban setting it is important that all spaces within and surrounding a school are healthy and safe. In Caroline Fusco's studies, emphasis was placed on classrooms, gyms and community facilities to ensure that a full safety plan and management tips were established. As the concern for sedentariness among the population grows, it becomes ever more important "to encourage safe and active transport options, more sidewalks, bicycle lanes, and pedestrian design features" (Fusco, 51).

\section{SPACES OF SALVATION}

Youth should be encouraged to take charge of their urban spaces. They should be encouraged by the civic leaders to be a part of the decision making and re-activation of their outspaces. Through this collaboration, the goal is to eliminate the adult-child barrier and encourage youth to participate in promoting active and healthy lifestyles.

DREAMING OF 'OUR FUTURE COMMON' SPACES

Parks and recreation spaces have the ability to build social cohesion and connectivity among the community. These common active spaces should be an equal opportunity for all races and economic stature. Urban spaces should constantly be reimagined for the youth of the current and future generations. Developing a healthy lifestyle for the youth can be added by the revitalization of the urban parks and recreation spaces. 


\section{IN AMERICA, 2 OUT OF 10 CHILDREN ARE CLINICALLY DIAGONSED AS OBESE.}

A growing body of research shows a gradual decline in physical activity and increase in a sedentary lifestyle for children. As a result, significant rises in obesity have occurred over the last three decades.

Figure 1.3

Decreasing a sedentary lifestyle learning.
In a study conducted by the Center for Disease Control and PreVEntion, tRENDS LEADING TO THE RISE IN OBESITY AND CHILDREN'S GRADUAL SLIP AWAY FROM THE NATURAL WORLD WERE OUTLINED AS FOLLOWS:

Children now spend nearly 30 hours a week watching a TV or computer screen, listening to something through headphones or, for older children, using cell phones or media players.

Children experience increasingly timed structured family lifestyles with less emphasis on unstructured outside time. Particularly in more densely populated countries, urban growth has eliminated green spaces and natural environments.

As the rates of obesity increase, there is the greatest increase in organized and commercialized sports for younger and younger children.

Instructional time outside, recess, or unstructured playtime is being eliminated from the school day.

Outdoor play spaces or playgrounds have become safer at some sites due to national playground standards, but in other locations, play spaces have been eliminated or often lack the natural elements that encourage a different kind of interaction among children.

The curriculum for children in centers and schools is becoming narrower, with more time spent on teacher-directed lessons and testing and less time spent investigating and learning through activities that build on a child's sense of wonder, curiosity, and the benefit of first-hand experiences. 


\section{ALMOST A QUARTER OF ELEMENTARY STUDENTS RECEIVE PHYSICAL -EDUCATION CLASS ONCE A WEEK.}

\section{PER CLASS}

Any scheduled PE

G 1 G 2 G 3 G 4 G 5 G

DAYS PER WEEK (percentage)

$\begin{array}{lllllll}\text { None } & 1 & 1 & 1 & 1 & 1 & 1 \\ \mathbf{1} \text { day } & \mathbf{2 2} & \mathbf{2 2} & \mathbf{2 2} & \mathbf{2 2} & \mathbf{2 2} & \mathbf{2 2} \\ \text { 2 days } & 33 & 33 & 33 & 33 & 32 & 28 \\ 3 \text { days } & 8 & 9 & 8 & 8 & 8 & 10 \\ \text { 4 days } & 3 & 3 & 3 & 3 & 4 & 4 \\ 5 \text { days } & 18 & 17 & 17 & 17 & 17 & 22 \\ \text { Varies by week } & 15 & 15 & 16 & 16 & 16 & 14\end{array}$

MINUTES PER CLASS (percentage)

$\begin{array}{lllllll}\text { None } & 1 & 1 & 1 & 1 & 1 & 1 \\ \mathbf{1} \text { to } \mathbf{3 0} \text { minutes } & \mathbf{4 3} & \mathbf{4 2} & \mathbf{3 9} & \mathbf{3 5} & \mathbf{3 4} & \mathbf{3 4} \\ 31 \text { to } 40 \text { minutes } & 24 & 24 & 25 & 26 & 25 & 24 \\ \text { More than 40 minutes } & 31 & 32 & 34 & 37 & 39 & 40 \\ \text { Varies by class } & 1 & 1 & 1 & 1 & 1 & 2\end{array}$

According to the Centers for Disease Control, elementary school aged children are recommended to have "60 minutes or more of moderate to vigorous physical activity that is developmentally appropriate, enjoyable, and involves a variety of activities" (Shephard, 252). Without structured PE classes, the appropriate levels of physical activity are typically not reached by most elementary children. While recess and other unstructured free play is vital for social interaction and the imagination, students do not meet the necessary recommended levels of physical activity during this play.

60 MINUTES OF MODERATE TO VIGOROUS PHYSICAL ACTIVITY IS NEEDED DAILY.

Sports programs are often viewed as a substitute for the PE classes offered in the school system. While sports typically engage children in the high level of physical activity required on a daily basis, they do not appeal to the vast majority of students. Sports are selective and children that do not develop the advanced motor skills or "natural talent" are left to stand on the side line.

Within an elementary school, children have numerous opportunities to receive physical activity through physical education classes, program integration with subject areas, recess, extracurricular programs, and active transport to school.

It is important to distinguish the difference between physical activity and physical fitness. "Physical Fitness is an outcome that has both performance-related and health-related components" (McKenzie, 171). Physical Education associated with a school setting encompasses both Physical Activity and Physical Fitness. $\mathrm{PE}$ is part of the standard school curriculum at varying levels and has defined educational objectives unlike recess or free play.

Evident from the 2005 survey completed by the US Department of Education, more and more elementary students are not receiving the recommended 60 minutes of daily physical activity in their PE classes. Students are typically not engaged in physical activity the entire PE class as well. Time is often wasted to organize the students as well as explain the rules. Additionally, the game or activity often does not involve every student activitely moving at all times.
"PHYSICAL ACTVITY IS THE PROCESS OF ENGAGING IN BODILY AND IT IS ESSENTIAL (MCKENZIE, 171 ) 


\section{MajOR PHYSICAL DEVELOPMENT OCCURS BETWEEN THE AGES OF 5 AND 10.}

This drawing illustrates the change in body composition from age 4 to 11 . It also highlights the importance of properly sized furniture for the different age groups. One size does

not fit all at the elementary level.

"Just a few generations ago, we walked, ran, lifted and carried, we pushed and pulled; we dug, harvested and gathered; we danced, jumped and climbed. But things have changed-we have changed. The opportunity and perceived necessity to move in modern life has declined dramatically. What hasn' $\dagger$ changed is that we still need to be physically active to survive. But what does physical activity actually mean?" (Designed to Move, viii)

Sadly more and more children are becoming inactive. Physical inactivity has become the norm. Parents are setting the example for children. Studies show that inactive parents tend to have inactive children. "About $41 \%$ of obese children and $80 \%$ of obese teens will become obese adults" (Ewing, 464). While our occupation home life and transportation means have changed dramatically over the last 40 years, the needs of our bodies have not. WE STILL NEED TO MOVE.

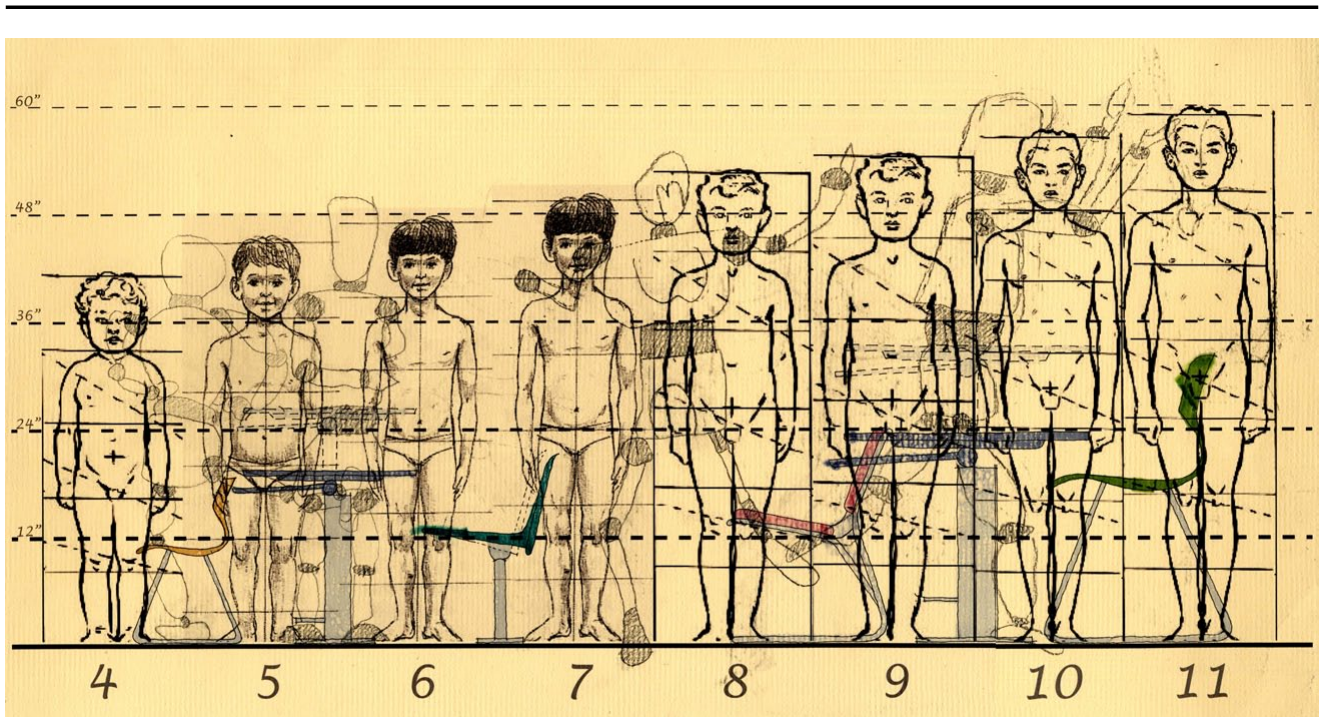




\section{FUNDAMENTAL MOTOR SKILLS}

Learning the fundamental motor skills as a child is equally as important as becoming proficient in reading and writing. Motor skills form the basis for which children learn to move and the advancement of these skills allow a child to engage in more rigourous physical activity. As a child's fundamental motor skills improve, the amount of independence from an adult increases. According to Jackie Goodway, associate professor of the School of Physical Activity \& Educational Services in the College of Education and Human Ecology at the Ohio State University, "the fundamental motor skills are the building blocks for later physical activity and sports and games." Children need both structured and unstructured physical activity. During the structured physical activity they gain the specialized instruction to further develop their motor skills. At the early stages of motor development, children learn one skill at a time. As their development continues, various motor skills are combined to form a specialized motor skill. For example, running and reaching to catch a fly ball combines all three categories: manipulative (catching), locomotor (running) and nonlocomotor (twisting and bending).

\section{MANIPULATIVE SKILLS}

involving

reception of

objects

throwing, striking

hitting, kicking,

catching

\section{LOCOMOTOR SKILLS}

involving the

whole body moving through space

climbing, sliding ascending and descending stairs running, walking, hopping, galloping skipping, leaping

\section{NONLOCOMOTOR SKILLS}

involving only specific parts of the body to move

pushing, pulling bending, curling, and twisting
This drawing explored the basic fundamental motor skills that a child must learn during their elementary years. A child's independence and freedom from the adult is gained as each motor skill is mastered. A variety of locomotor skills are present in the drawing from skipping, hopping, and walking up the blue ramp to climbing the ladders. Locomotor skills allow a child to travel to and from levels on the same plane as well as ascend and descend. Several manipulative skills are also illustrated from throwing to kicking to catching.

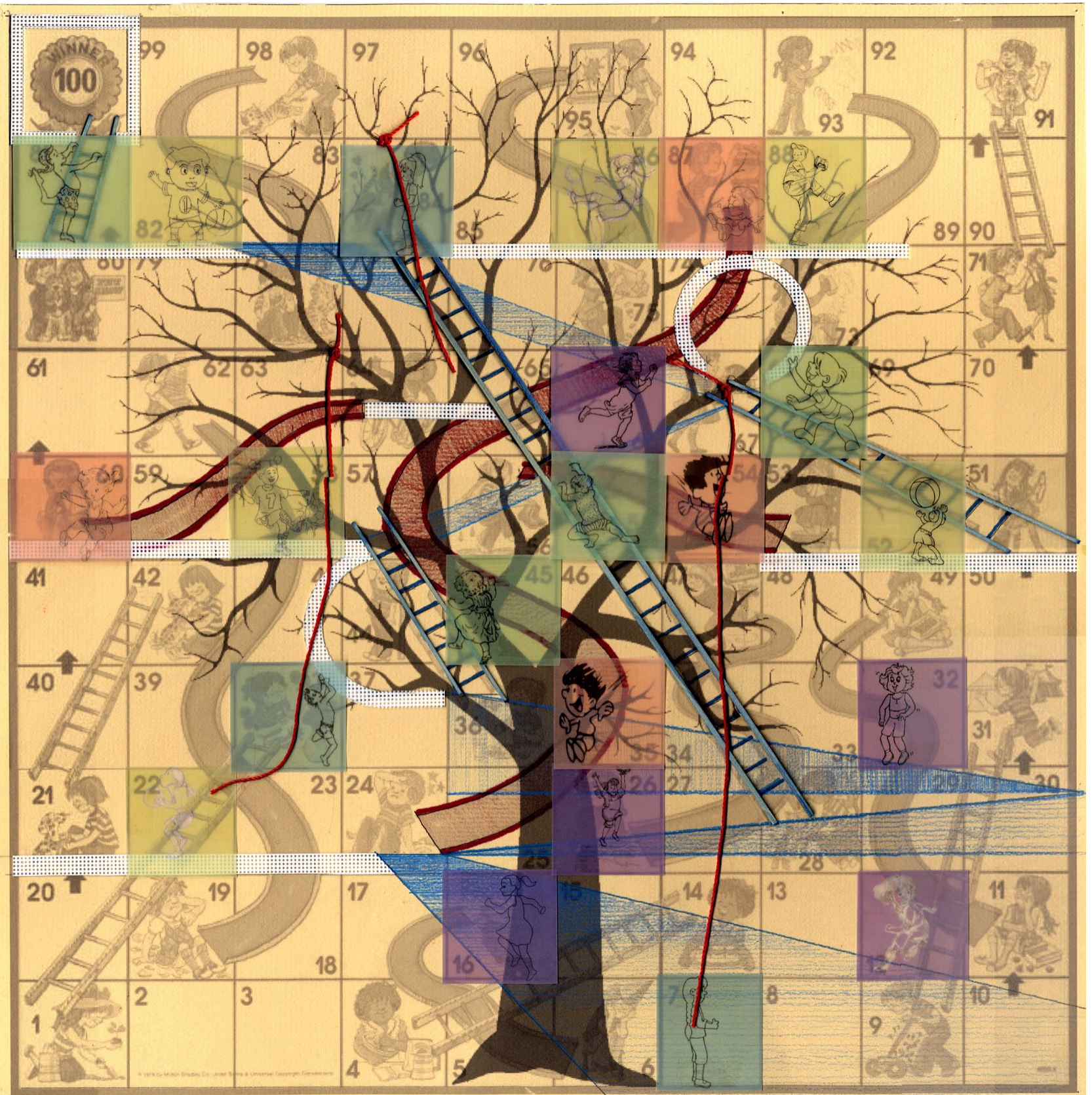




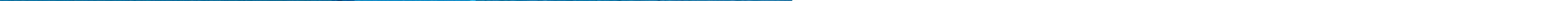




\section{WHAT IS PLAY?}

Stuart Brown, M.D., has built a career around studying play. He has analyzed play from all sides and in his book PLAY, he outlines "how it shapes the brain, opens the imagination, and invigorates the Soul."

According to Stuart Brown, "Play" is broken into seven properties:

"The first quality of play that sets it off from other activities is its APPARENT PURPOSELESSNESS. Play activities don't seem to have any survival value. . . It is also VOLUNTARY. . . Play also has INHERENT ATTRACTION. It's fun. It makes you feel good. It is a cure for boredom. . . Play provides FREEDOM FROM TIME. . . We also experience DIMINISHED CONSCIOUSNESS OF SELF. we stop worrying about whether we look good or awkward, smart or stupid. . . Another hallmark of play is that is has IMPROVISATIONAL POTENTIAL. We aren't locked into a rigid way of doing things. . Last, play provides a CONTINUATION DESIRE. We desire to keep doing it" (Brown, 17-18).

"Might we not say that every child at play behaves like a creative writer, in that he creates a world of his own, or rather, rearranges the things of his world in a new way which pleases him?" (Freud, 25)

Play is done for its own sake. . .

It is not obligatory or required by duty. . .

It provides psychological arousal. .

We lose a sense of the passage of time. .

We can even be a different self. .

We are open to serendipity, to chance. . .

And when it is over, we want to do it again. .

(Brown, 17-18).

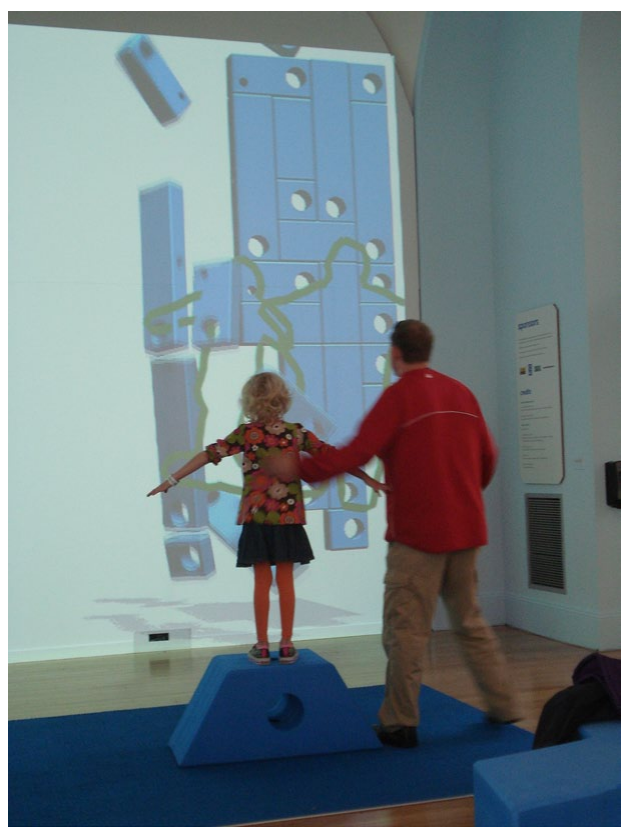


ChILDEN EXPERIENCE FOUR TYPES OF PLAY.

Each type is important for their

LANGUAGE development,

PHYSICAL development,

"PlaY IS IMPORTANT FOR

HEALTHY BRAIN DEVELOPMENT"

EMOTIONAL development,

SOCIAL development,

"Play allows children to use their creativity while developing their imagination, dexterity, and physical cognitive, and emotional strength" (Ginsburg, 183).

and COGNITIVE development.
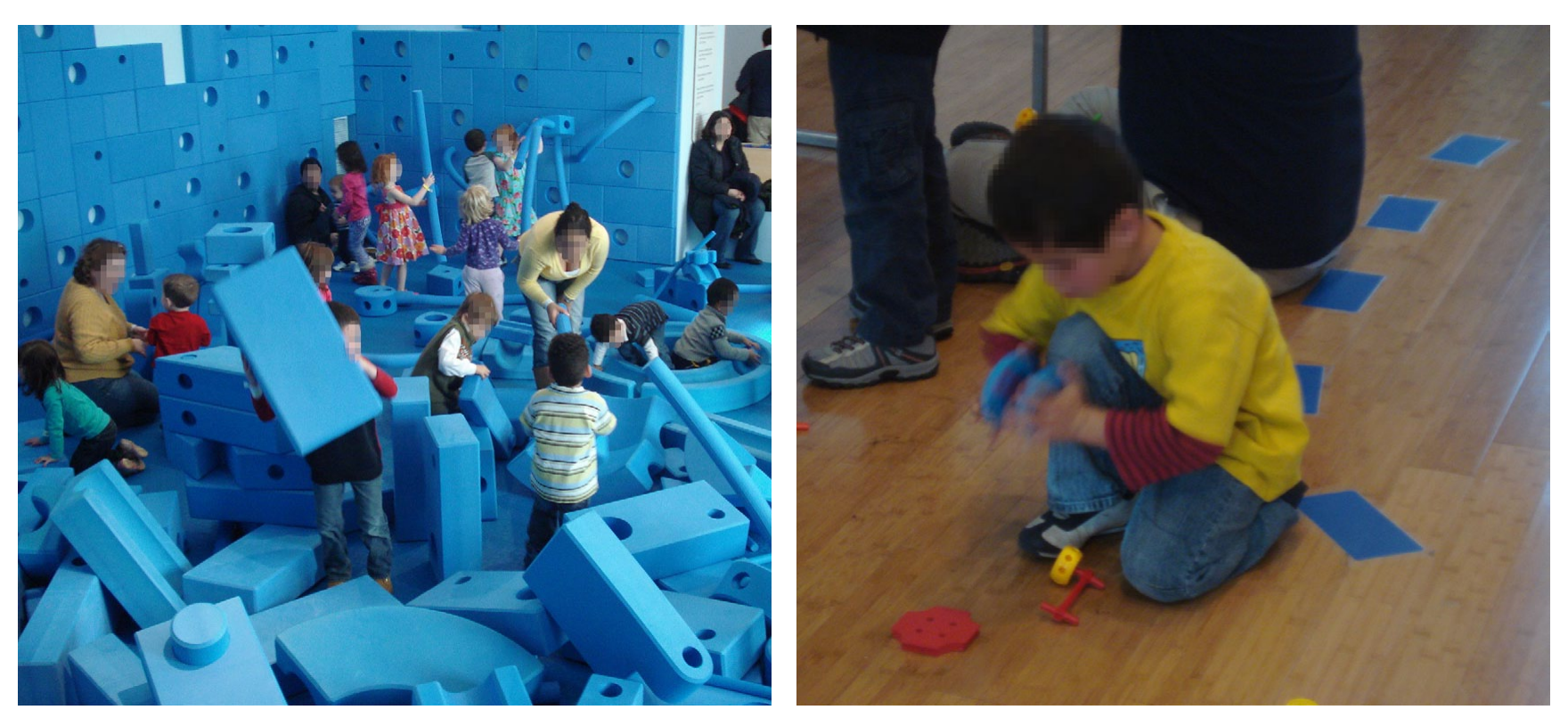
FOUR TYPES OF PLAY (Brown, 83-88)

LOCOMOTOR PLAY

This type of play begins even within the womb. Infants feel the urge to squirm and move around. As their mobility increases the movements become more complex and they begin to rock and crawl. Very few movements are random, they are "behaviors that promote exploration and learning." Movement provides us with an understanding of our surroudings. As we move we are in a constant state of thought. "Movement lights up the brain and fosters learning, innovation, flexibility, adaptability, and resilience." (Brown, 83)

\section{OBJECT PLAY}

Early on, infants and toddlers search for objects to touch. It is through this exploration of the object that the brain begins to enrich its object awareness and memory. As the child grows, the objects become more complex along with the child's use of the object.

\section{IMAGINATIVE PLAY}

maginative play begins at the age of two with fragmented stories. As the child grows, so does their ability to create a coherent narrative on their own bringing the imagination to higher level. Children continue to explore the boundaries of reality and pretend.

\section{SOCIAL PLAY}

Social play can be as simple as a game of peekaboo to a formal homecoming dance. Social play is vital for individual and large group relationships. Social play can be further divided into: friendship and belonging, rough-and-tumble play, and celebratory and ritual play.

\section{PROCESS OF PLAY}

Scott Eberle is an intellectual historian of play and vice president for interpretation at the Strong National Museum of Play in Rochester New York. Eberle has organized the process through which people play into a six-step process that starts with anticipation and ends with poise. With a new source of anticipation, the cycle of play repeats itself again. (Brown, 19)

ANTICIPATION, waiting with expectation, wondering what will happen, curiosity, a little anxiety. .

SURPRISE, the unexpected, a discovery, a new sensation or idea, or shifting perspective.

PLEASURE, a good feeling, like the pleasure we feel at the unexpected twist in the punch line of a good joke. .

UNDERSTANDING, the acquisition of new knowledge, a synthesizing of distinct and separate concepts, an incorporation of ideas that were previously foreign. .

STRENGTH, the mastery that comes from construction experience and understanding, the empowerment of coming through a scary experience unscathed, of knowing more about how the work works.

POISE, grace, contentment, composure, and a sense of balance in life. . . new anticipation.

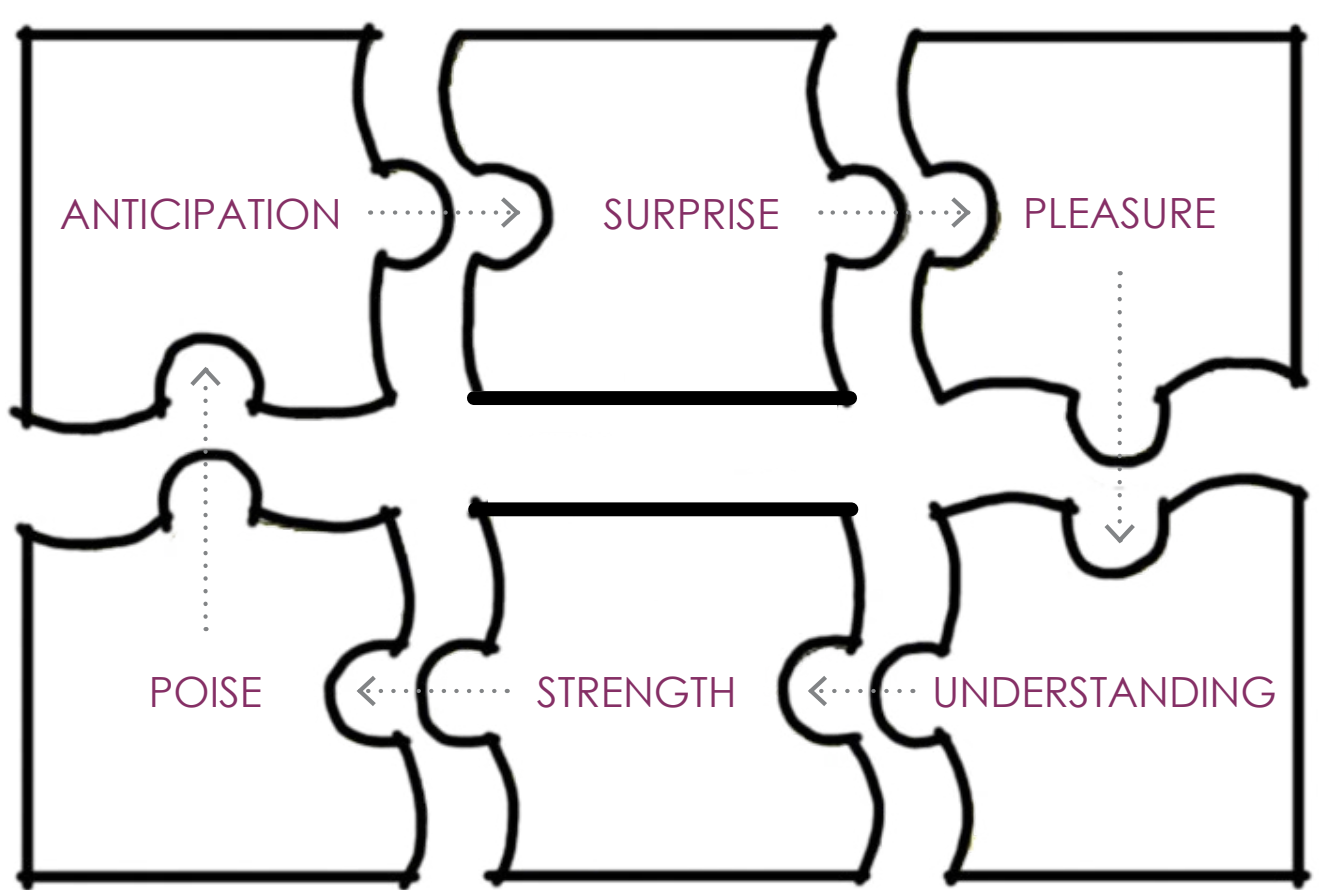




\section{LEARNING FROM PLAYGROUNDS}

"Let's begin with the obvious: kids like to climb, and run, and get their hands on anything that could (and probably will) break. They like to explore and imagine, create and destroy and create again." http://www archdailycom/214274/forming-playscapes-what-schools-canlearn-from-playgrounds/ Accessed 29 May 2013.

Thanks to Ken Robinson's talk in 2007 at TedTalk, the idea that children are little adults is slowly being left behind. Children should be treated as children and thus the design of a school should reflect the needs of the child. As designers we can look at playgrounds as a source of inspiration not only for their color and scale, but their ability to inspire imagination. Schools as well as classrooms need learning, and experimental learning.

Playgrounds and perhaps schools should be designed to challenge children with the potential to fall. A playground that is too safe does not teach a child the basic lesson that when you fall you get back up and try again. The following three drawings not only illustrate designs for movement, they also demonstrate the Active Design approach where movement is integrated into traditionally static architecture drawings.

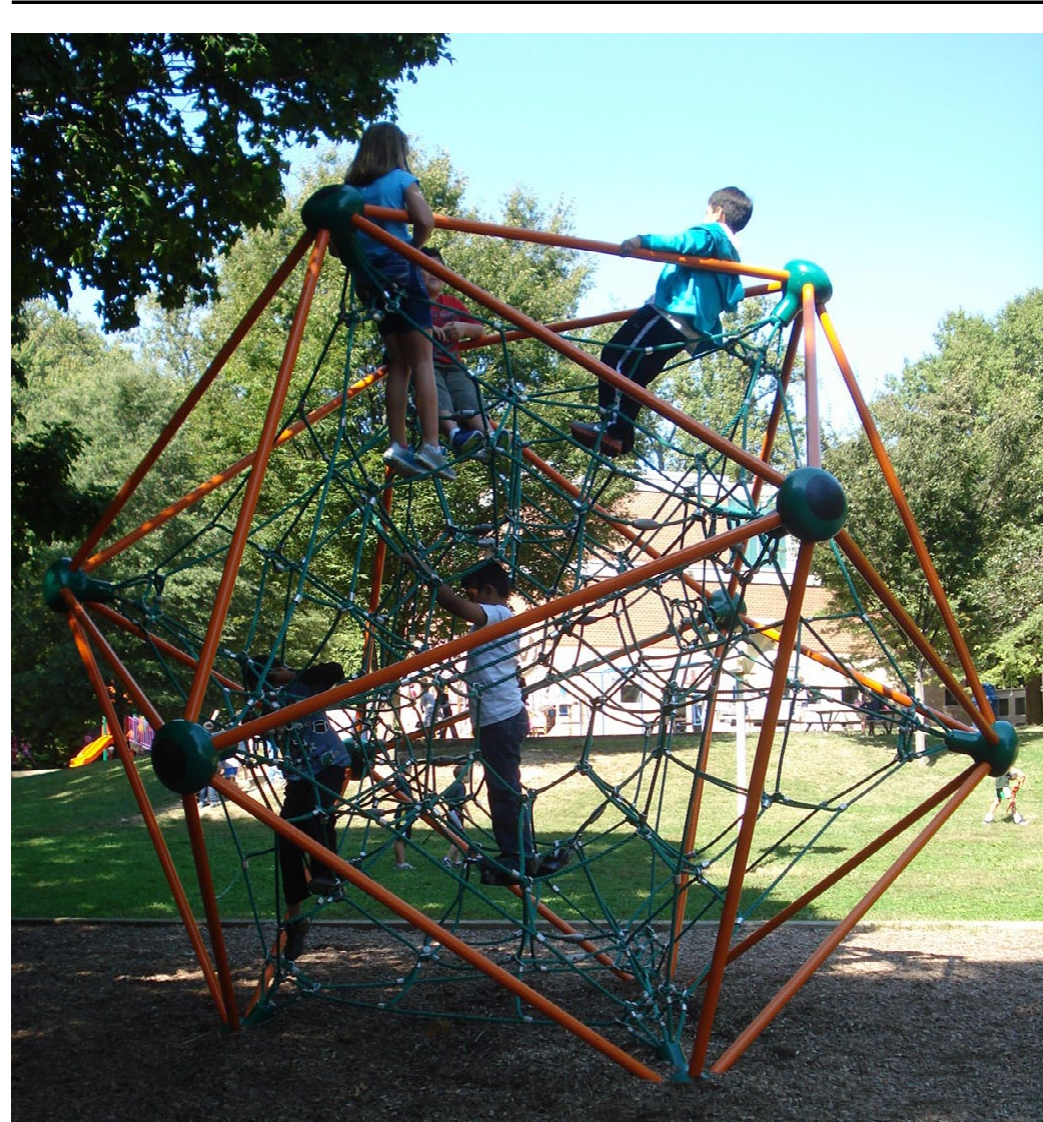

Figure 2.5

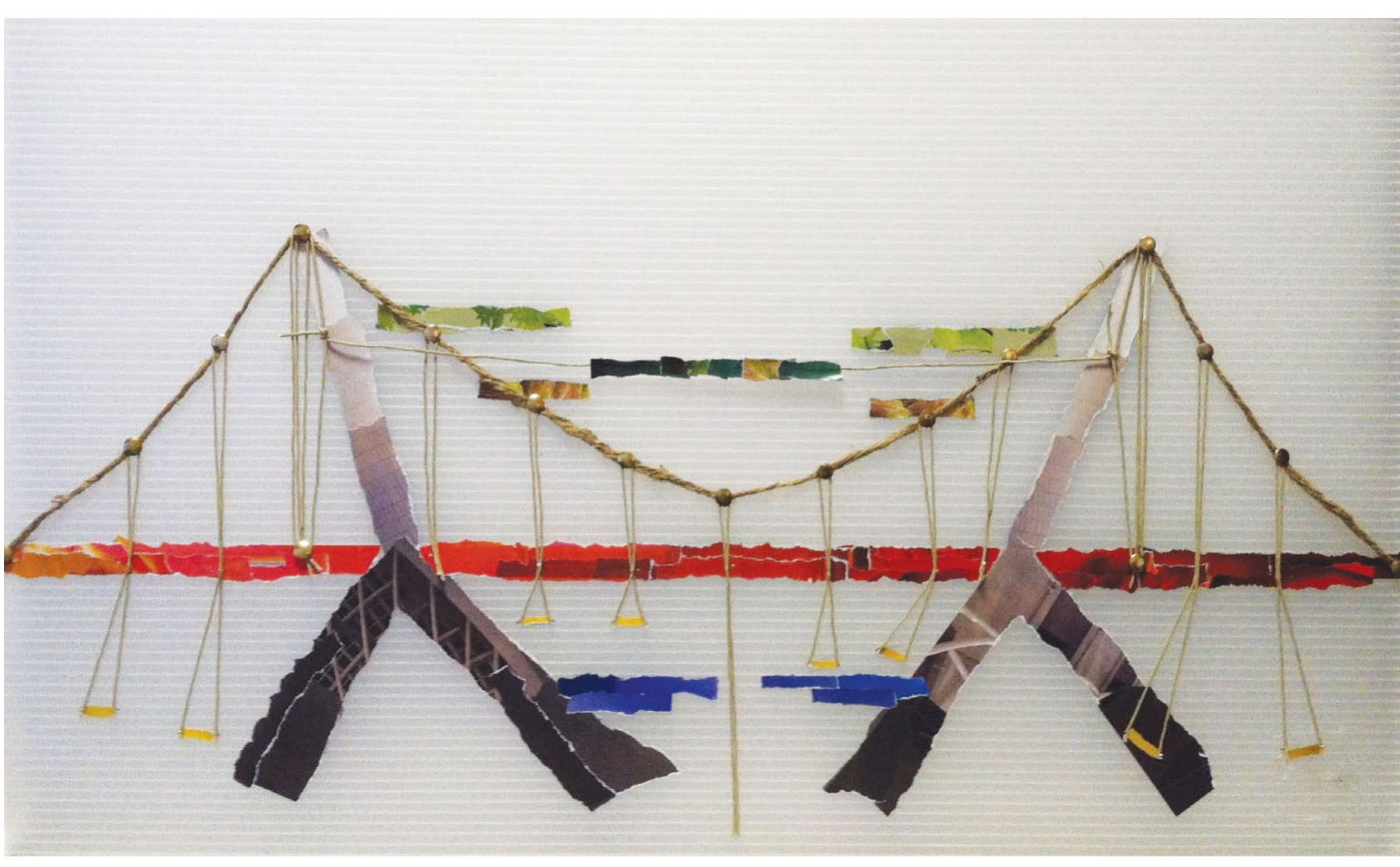

SWING

Figure 2.6

The 3 S's of

Playground:

SWINGS OFFER OPPORTUNIIIES MUCH MORE COMPLEX THAN SIMPLY "EXERCISE." (STINE, 20)

The playground provides an outdoor space for children to learn while also developing their fundamental motor skills. A sense of self-independence is gained when a child finally learns to pump a swing on their own. They are no longer dependent on the adult to push them and without fully understanding this new ability they have also advanced their manipulative and locomotor skills. Swings also offer social experiences whether that be with an adult or with a peer sharing the tire swing. Additionally, there are endless problem-solving activities that take place with learning to share the swings. The above drawing explores the idea of transforming the swing beyond a playground element only and into a building element. Swings have the potential to provide the necessary movement to encourage fidgeting and provide the basic elements of a seat and desk. 
Figure 2.7 The 3 S's of the Playground: "THE SLIDE"

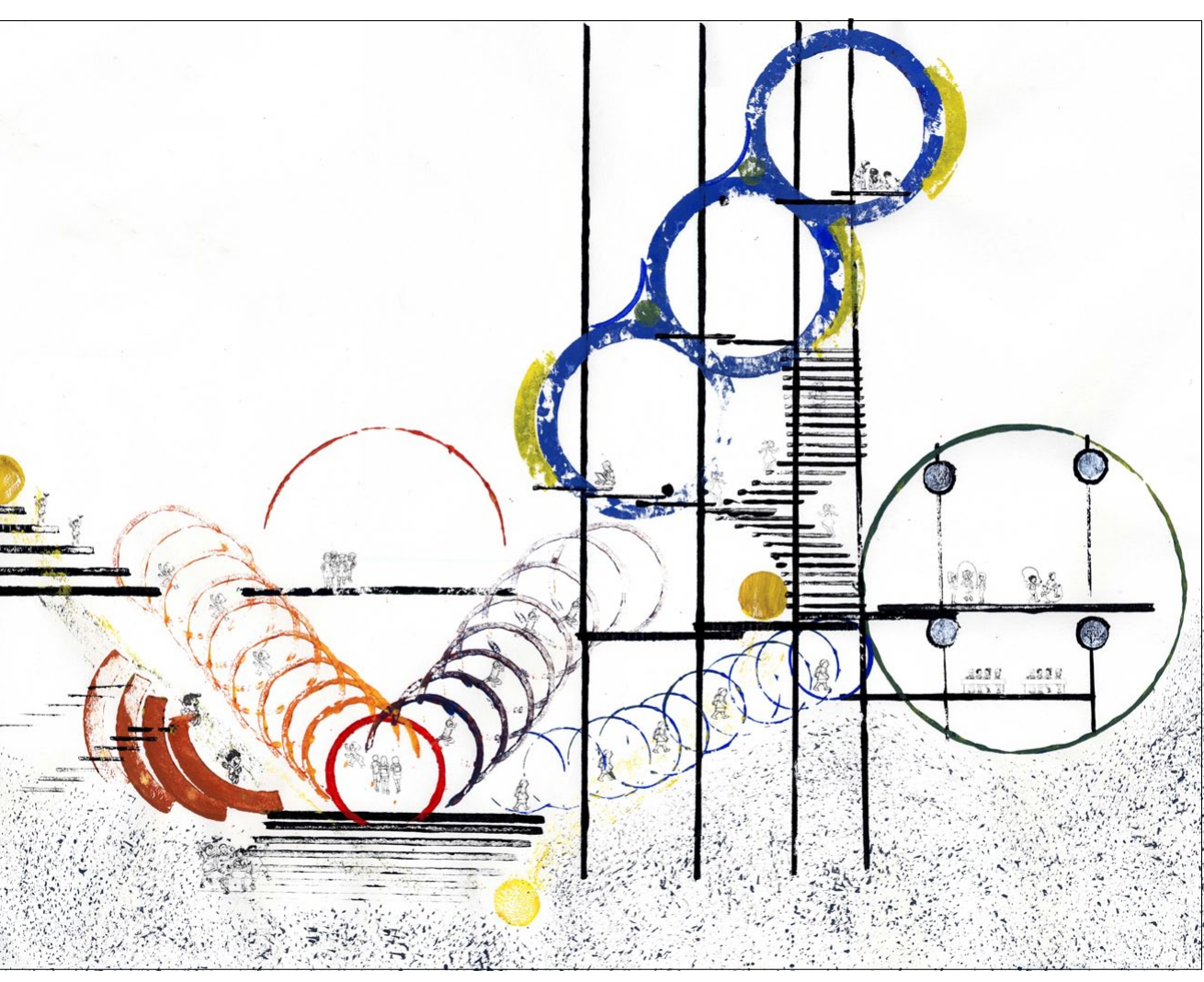

SLIDE

WHEN A SLIDE GETS BORING GOING DOWN WHY NOT RUN UP IT.

Slides provide endless opportunities for both play and physical activity. Kindergarten students develop a sense of freedom when they no longer need the assistance of their parent or teacher to slide down. For a second grader the slide becomes a game, a challenge set forth by their classmates. The idea of simply sliding down with your feet first has become all together boring. Now it has evolved into a challenge of who can climb up the slide fastest ten race across the suspended bridge through the tunnel and down the pole. This drawing illustrates the way in which slides could be used architecturally as a way for children to move through the building whether climbing or sliding.

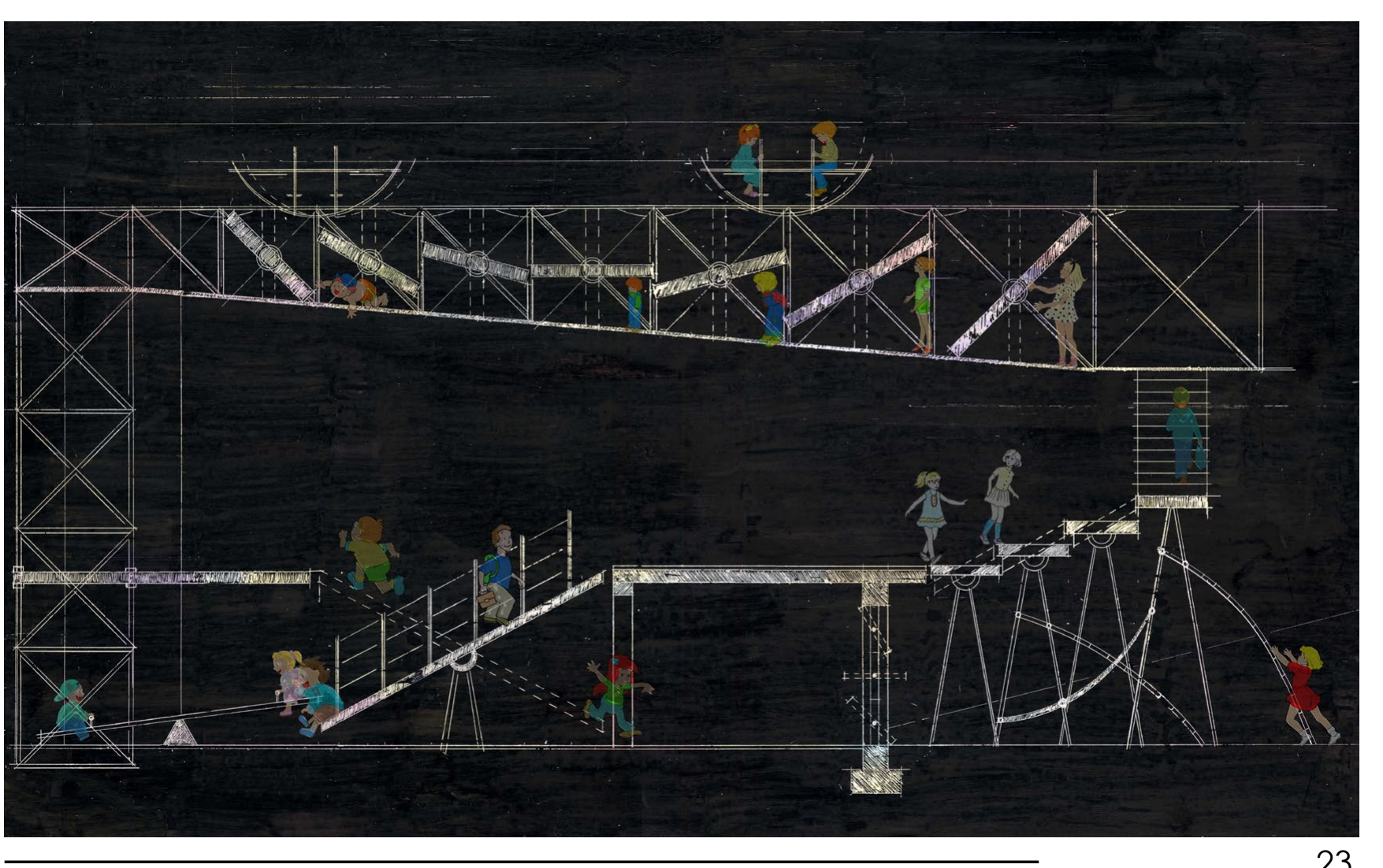

SEESAW

SIMPLE PLAYGROUND EQUIPMENT LIKE THE SEESAW, ENGAGES CHILDREN SOCIALLY, PHYSICALLY, AND COGNITIELYY.

Figure 2.8 The 3 S's of the Playground: "THE SEESAW"

A seesaw is not meant for individual use. For it to function and be "fun" two or more children must interact on opposite sides. Through this social interaction children learn to work with their neighbor. At the same time physical activity of moving up and down has engaged the child in a playful way. A child's first understanding of how a simple machine works as a fulcrum and lever is through the seesaw. While it may appear that a child is merely playing on the seesaw there is a cognitive awareness that comes from discovering how a shift towards or away from their neighbor they are able to get the seesaw in an equilibrium position and balance. 


\section{SCHOOLS ARE THE FOUNDATION OF}

\section{AN ACTIVE COMMUNITY, DIRECTLY} INFLUENCING A CHILD'S LIFE.

Children rely on their adult influences and communities to set examples for their later years. If the world around them is leading an active, healthy lifestyle, children are more likely fo follow. A school can be the central active zone within the urban landscape. Families travel to the school for both play and learning. Public facilities within the school grounds for the whole family are critical in establishing healthy lifestyles.

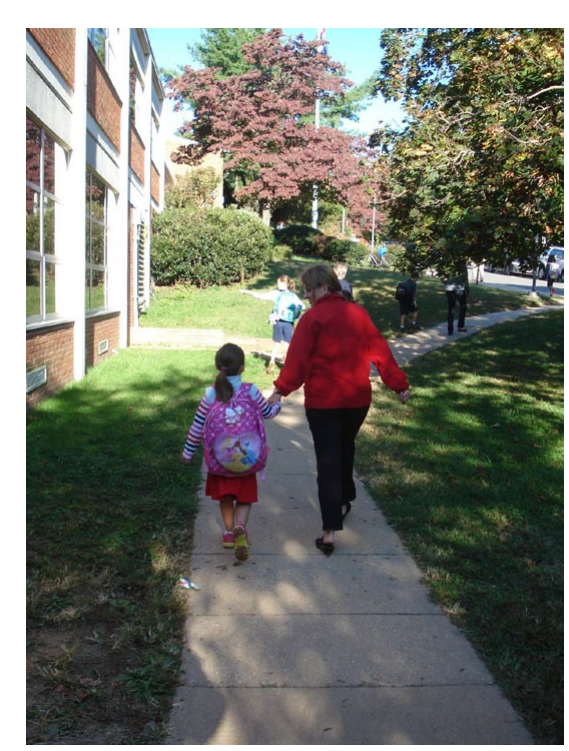

THE TOTAL U.S. PUBLIC STUDENT MEMBERSHIP FOR THE 2009-10 SCHO0L YEAR FOR GRADES K־5 WAS 22,136,012.

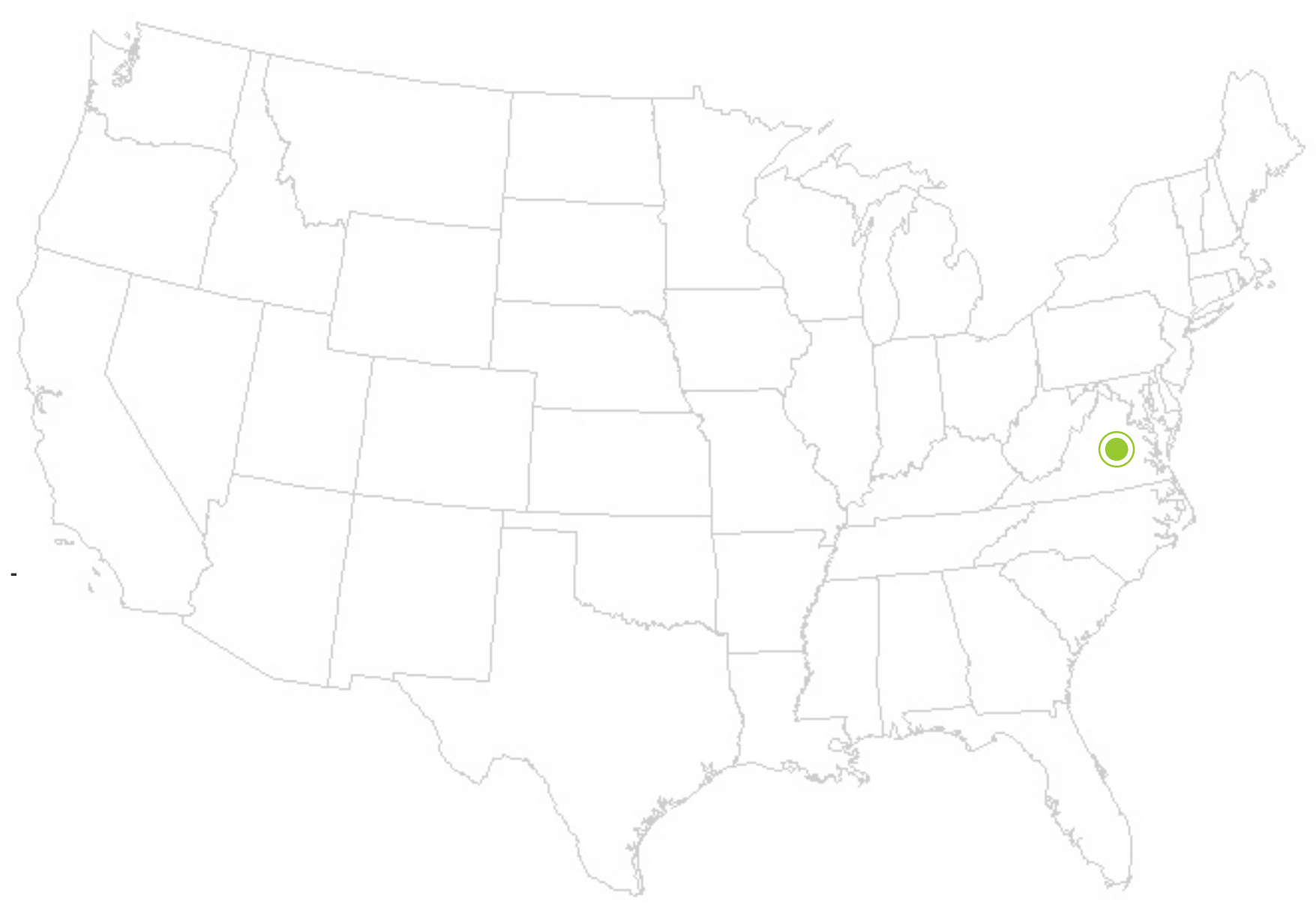

During the 2009-10 school year, the State of Virginia had 558,325 elementary students enrolled in Kindergarten through 5 th Grade.

As of October 2011, Alexandria City Public Schools (VA) had 12,357 students enrolled in

PreK-12th grade.

U.S. Department of Education, National Center for Education Statistics (2011). Public Elementary and Secondary School Student Enrollment and Staff Counts from the common core of date:

$22,281(\mathrm{~K})$

$93,977(1 \mathrm{st})$

93,141 (2nd)

$93,366(3 \mathrm{rd})$

$93,708(4$ th $)$

$91,852(5$ th) 


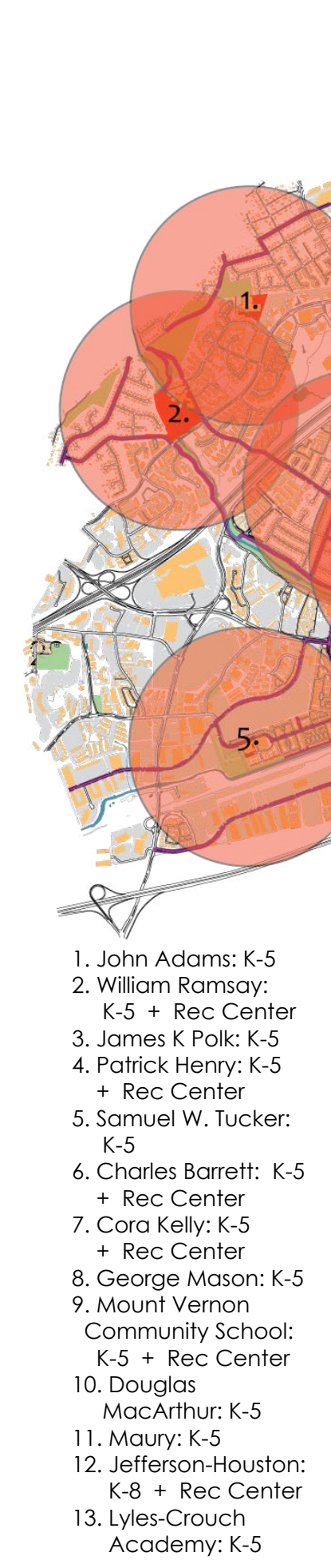

The City of Alexandria, VA currently has 13 existing elementary schools. As the city continues to grow, a greater demand shows a new elementary school is needed. To determine the site selection for the proposed elementary school the existing schools were mapped and identified with a half mile radius shown around the school indicating the encouraged walk/bike zone.
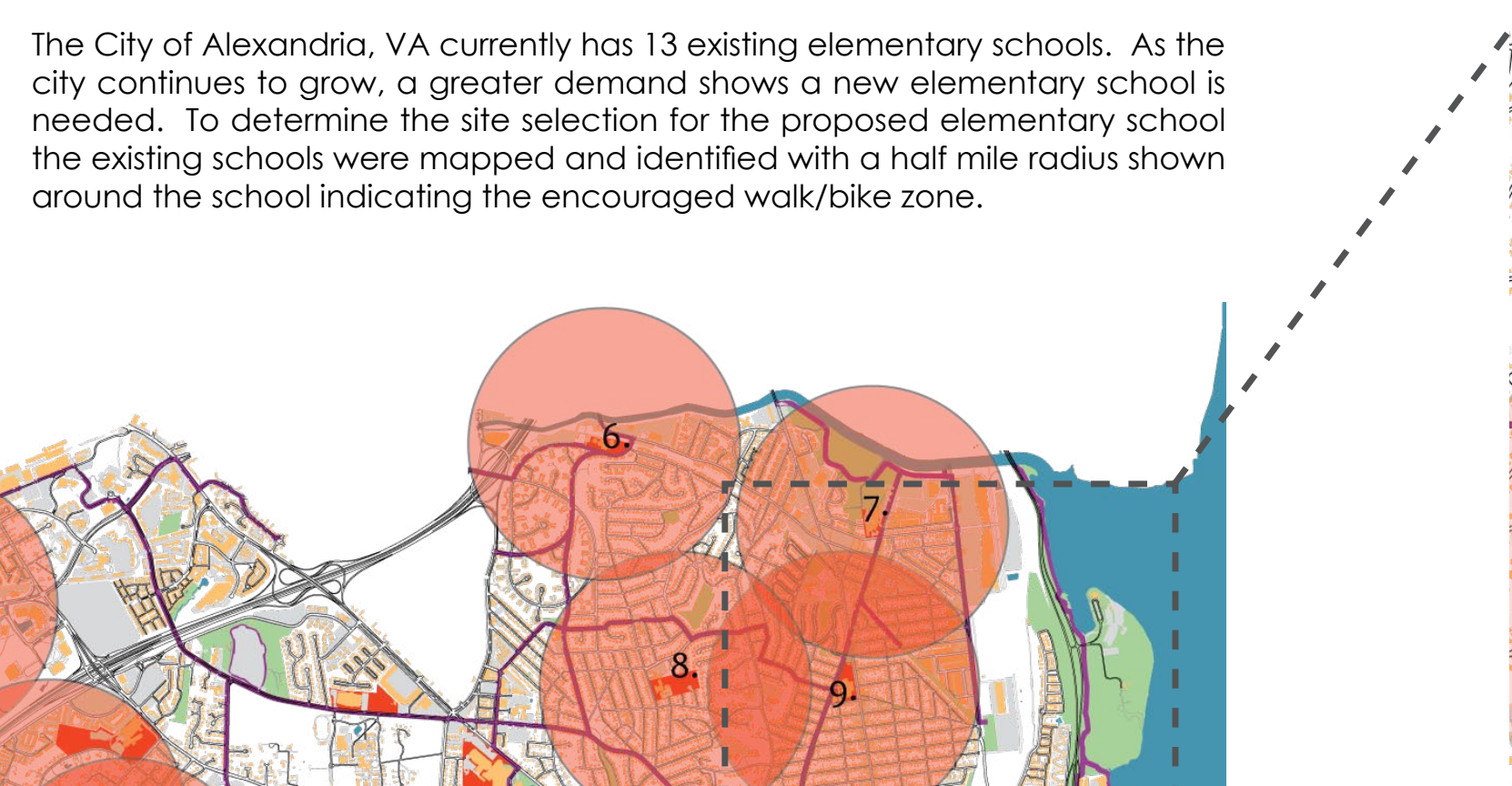

3.
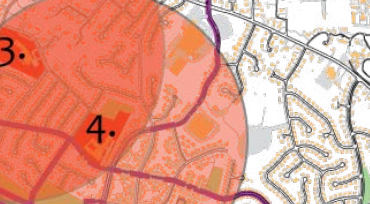

7.

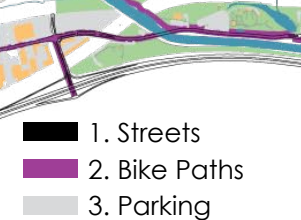

2. Bike Paths

4. River/Streams

5. Parks

7. Existing Alexandria City Public Schools

Mapping the existing schools revealed a great demand for a new school in North Old Town/Parker-Gray neighborhood on the southern edge of the new Potomac Yard Development where no circles are present.

The Potomac Yard Development, just north of Old Town Alexandria, has recently experienced high residential growth and will continue to for the next 10-15 years. As demonstrated by the city wide map of Alexandia's existing elementary schools, this neighborhood lacks an elementary school that is walkable and bikable.

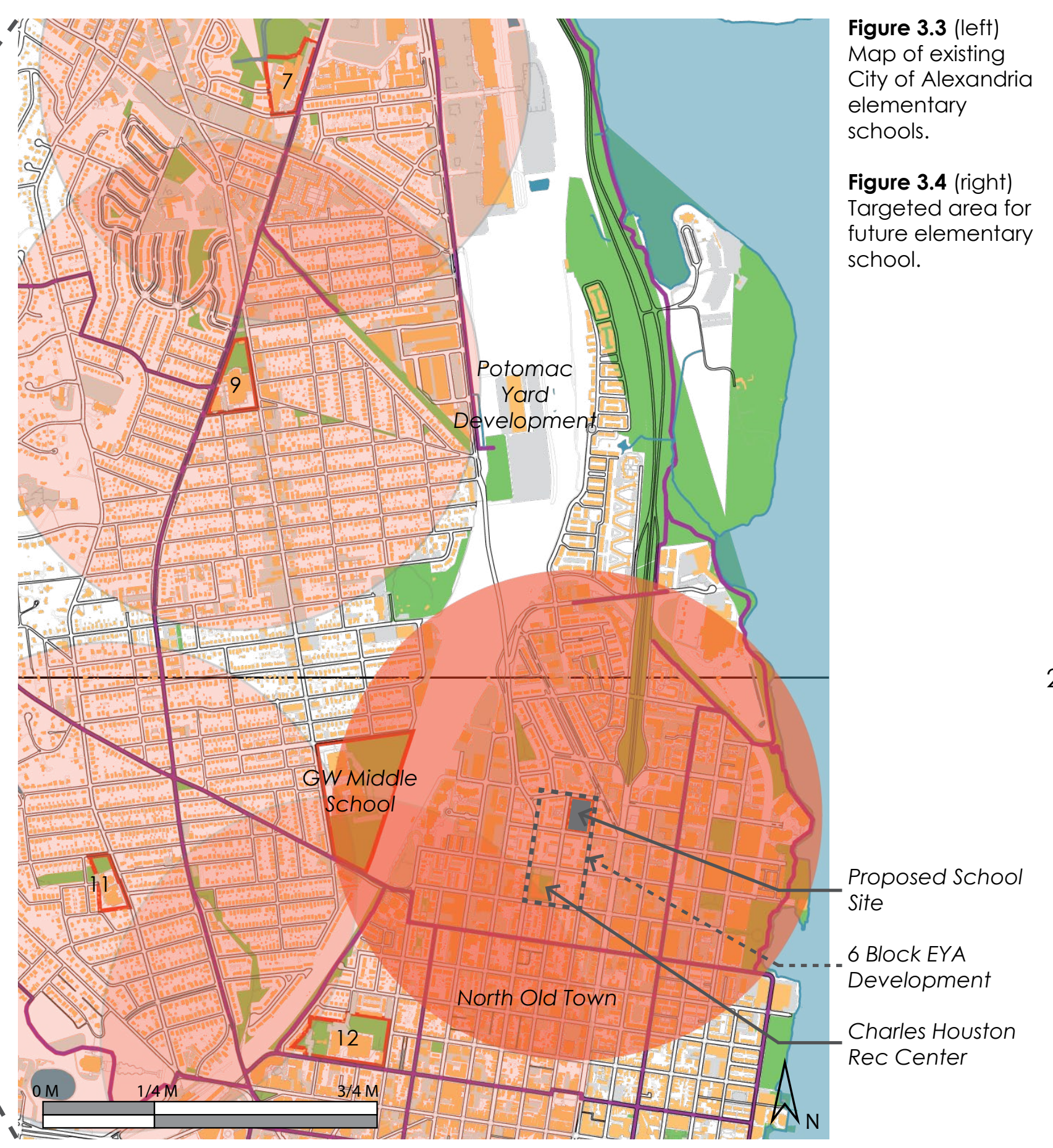

In a six block area bounded by Route 1 to the West, 1st Street to the North, N Columbus Street to the East, and Wythe Street to the South. EYA Development is in the middle of a redevelopment of the existing six residential blocks. This location is an excellent area for a new urban school do to its proximity to the location is an excellent area for a new urban school do to its proximity to the Braddock Road Metro and residential densily surounding the city blocks. The ing high and accessible location for an elementary school. 


\section{PARKER-GRAY ELEMENTARY SCHOOL}

The following text is from "Alexandria's African American History - Black Education and Park-Gray School."

The proposed elementary school site
sits within the sits within the northeast corner Parker-Gray Parker-Gray District. This
area is named area is named after the first co-ed African American Elementary School founded in 1920.

THE SNOWDEN AND HALLOWELL SCHOOL was located at the time on Wolfe and Royal Streets. principal of the Hallowell School for Girls.

\section{PARKER-GRAY AND LYLES-CROUCH SCHOOLS}

The Snowden and Hallowell schools were the first black public schools in the City of Alexandria. In 1915, the Snowden School for Boys was destroyed in a fire, but the students were allowed to attend St. Mary's Catholic Church School which

In 1920, the Snowden and Hallowell schools were consolidated, and the resulting school was named the ParkerGray School. Parker-Gray School is named for John Parker, principal of the Snowden School for Boys, and Sarah Gray,

The first Parker-Gray School, located at 900 Wythe Street, opened in 1920 for children in grades one through eight. It had nine teachers and the barest necessities. Members of the community provided chairs and basic equipment. . . For many years, African American students had to travel to Washington, D.C. to receive an education beyond the eighth grade.

By the early 1930s the school was overcrowded. A new school was established in an old silk factory at the corner of Wilkes and South Pitt streets for Negro children who lived south of Cameron Street. It was named Lyles-Crouch to honor Jane Crouch and Rozier D. Lyles. Mrs. Crouch was a principal at Hallowell School; Mr. Lyles taught at Snowden School and at the first Parker-Gray School.

Parker-Gray was soon overcrowded again, so classrooms and a library were added. The first students attended ParkerGray for grades eight through eleven graduated in 1936. (Virginia required only 11 years of public education then.)

When the Parker-Gray High School was built in 1950, the original Parker-Gray School was given the name of Charles Houston, the NAACP lawyer who helped the community in their quest to have the High School built. During the desegregating years, Charles Houston Elementary School closed (1979) and the building eventually burned down. This site is now home to the Charles Houston Recreation Center.

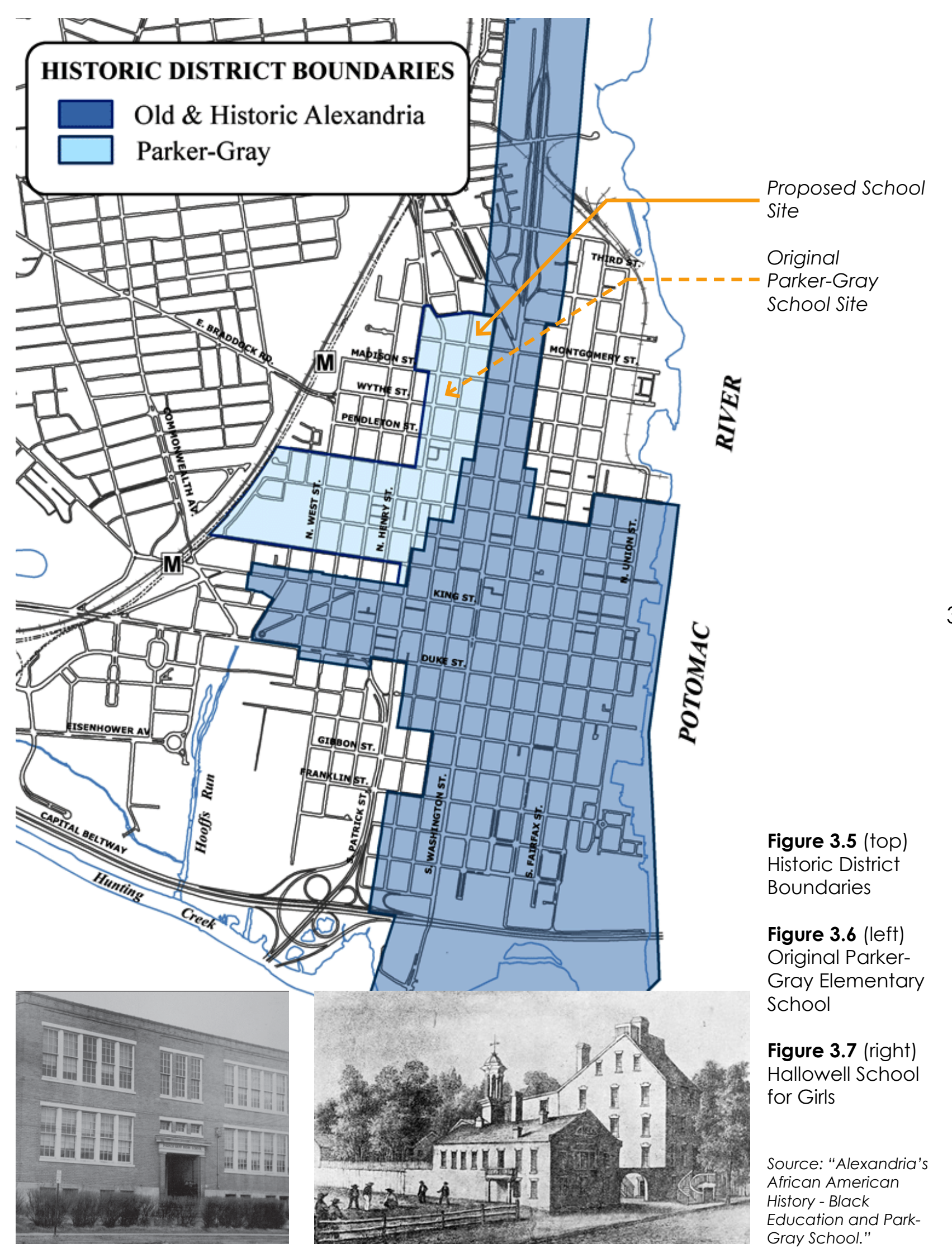




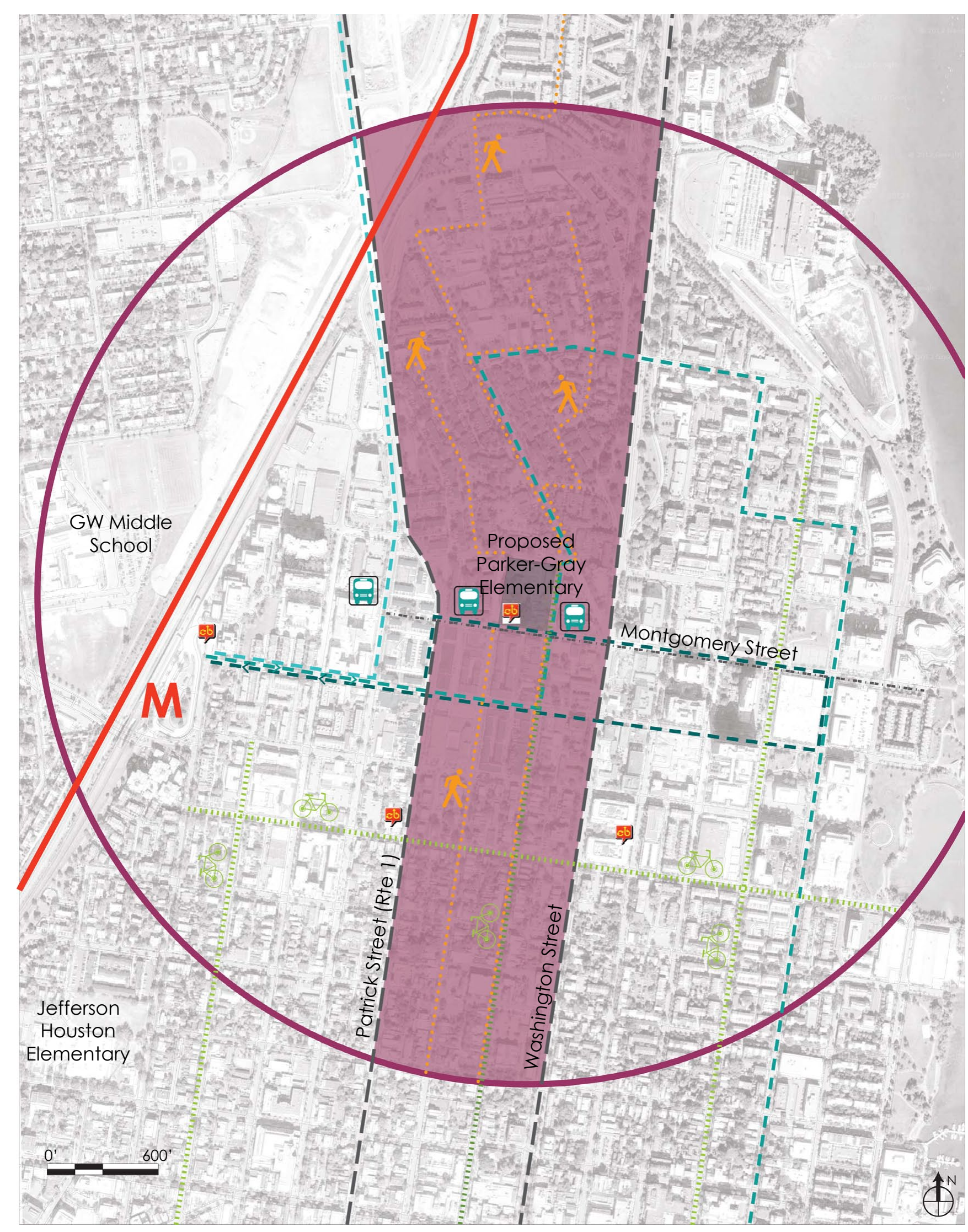

A school nested within an urban community serves as a symbol for Figure $\mathbf{3 . 8}$ (left) learning and play for all ages. Parker-Gray Elementary is located Active at a major transition point between historic North Old Town and transportation the new neighborhood development of Potomac Yards. Notonly Diagram. the new neighborhood development of Potomac Yards. Not only does the school have the opportunity to bridge the neighborhood separation, but it can become an example to encourage a healthy active lifestyle across the community.

The proposed Parker-Gray Elementary is sited to encourage both adults and children to arrive at the school via multiple modes of active transportation beyond the personal vehicle. These modes include walking, biking, bus, and metro.

\section{WALK ( $1 / 2$ MILE RADIUS)}

The purple circle indicates the $1 / 2$ radius surrounding the school. The shaded purple area represents the targeted area of walkers/bikers that fall between the busy streets and within the $1 / 2$ mile radius.

\section{WALKING}

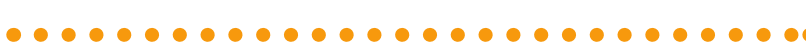
The existing urban neighborhood as well as the growing development of Potomac Yards provides an excellent sidewalk network for the children to safely arrive at school.

\section{METRO (BRADDOCK ROAD)}

The Braddock Metro is less than a 1/2 mile from the proposed school. A large bus network as well as a recent bike share location are located right outside the metro.

\section{BIKE (BIKE SHARE) 등}

Both adults and children are encouraged to bike to school. Dedicated bike lanes within the urban streets are indicated in green. Children are encouraged to use the well established neighborhood sidewalks to bike to school. BUS (DASH \& METROBUS)
Several existing bus stops are located within blocks of the school. The routes connect users to most of Alexandria as well as the greater Washington area.

ROADS

Patrick Street (Rte 1) and the Washington Street (GW Memorial Parkway) are major thorough fares that connect Alexandria to downtown Washington, DC. The school is located in such that it falls between theses two majors streets, making accessibility to the school easy, while also avoiding the school bound by either street. Montgomery Street, a one-way street traveling west, runs along the southern boundary of the site. 


\section{SCHOOL BASED HEALTH CENTERS}

Public Schools have the opportunity to serve as the heart of communities. They promote academic achievement and lifelong learning. However, schools can serve the community beyond providing a strong academic foundation. They can be the foundation for promoting a healthy lifestyle among young children.

Potential services provided by the school based health center may include:

\section{HEALTH IS A STATE OF COMPLETE PHYSICAL,}

\author{
MENTAL, AND SOCIAL WELL-BEING AND NOT
}

MERELY THE ABSENCE OF DISEASE OR INFIRMITY. communityresources for children and adults. A school-based health center attached to a public school is an opportunity to provide health services and develop commuity awareness of health related issues.

\section{PHYSICAL HEALTH SERVICES}

- care for acute illness and injury care for chronic conditions such as asthma and diabetes

physical exams

sports physicals

\section{MENTAL HEALTH SERVICES}

depression, anxiety and other illnesses

substance abuse

- violence prevention counseling

- family problems

tobacco cessation and prevention

weight gain and obesity management ADHD

\section{DENTAL SERVICES}

$\begin{array}{ll}\text { - screenings } & \text { - extractions } \\ \text { - sealants } & \text { - root canals } \\ \text { - fillings } & \text { - referrals }\end{array}$

\section{HEALTH PROMOTION ACTIVITIES}

- teaching health consumer skills

-encouraging avoidance of health risks

through promotion and awareness programs

providing venues for community partners

$$
\text { in teaching healthy lifestyles }
$$

\section{ADDITIONAL SERVICES}

health education for individuals and through classroom instruction

- nutritional counseling

- referral and follow-up for specialty services - provision for or referral to pregnancy testing and counseling

-laboratory and pharmacy on-site 


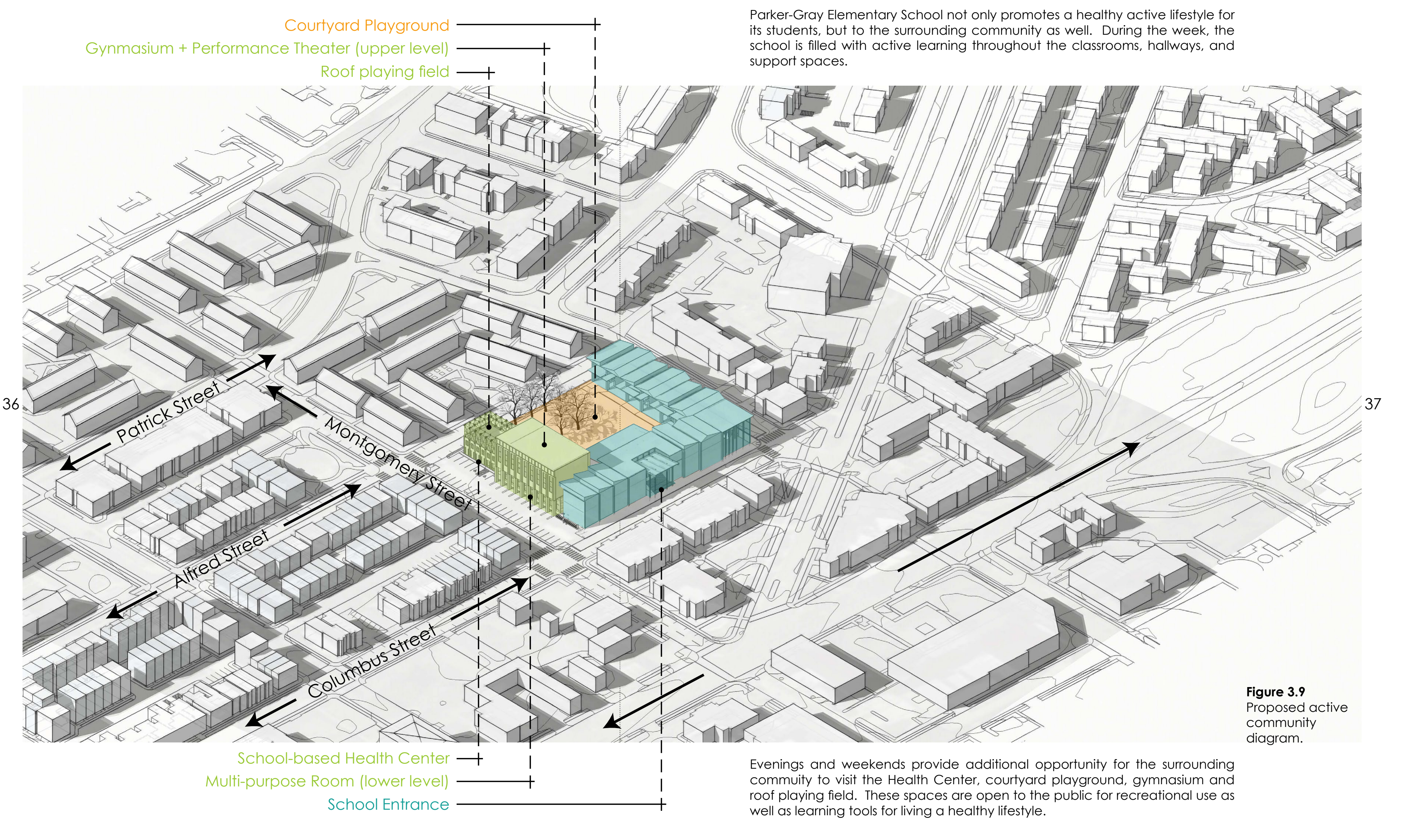




\section{A SCHOOL PROVIDES ONE OF THE FEW}

\section{OPPORTUNITIES FOR CHILDREN TO ENGAGE IN}

PHYSICAL ACTIVITY, PLAY, AND LEARNING IN ONE

\section{LOCATION.}

The importance of play as it relates to physical activity and a healthy lifestyle has been underemphasized in the design of elementary schools. Children spend a signifcant amoun of their childhood at school thus creating the perfect setting for play and movement to be incorporated. For children play should be fun, not work. Movement and physical activity should come about naturally as a result of play and not forced in thirty minutes of physical education class. Play should happen both inside and outside. Play should be incorporated into all aspects of learning and should be visible at all times. Play should be viewed as a time for a child to developmentally grow and learn.

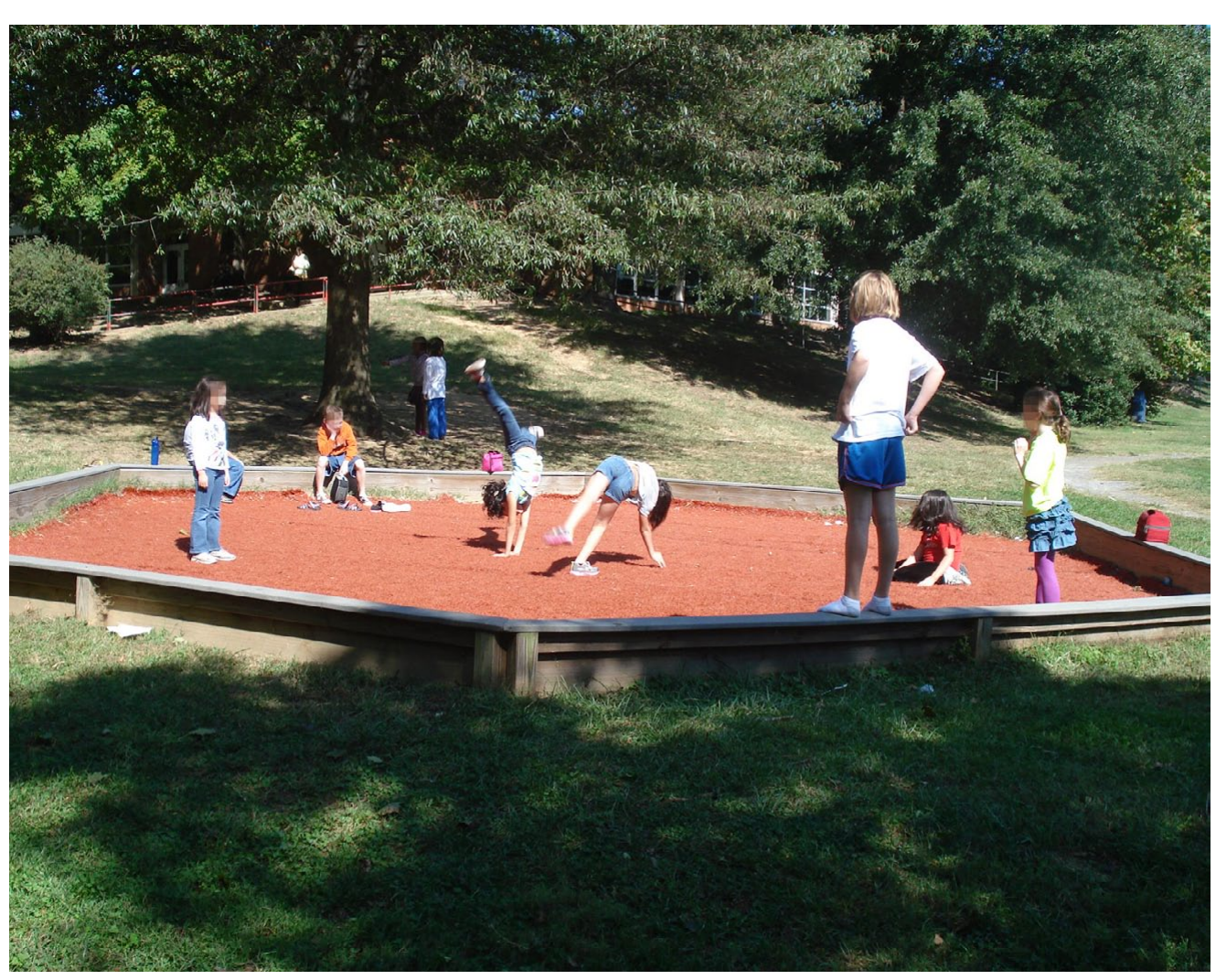

figure 4.2 Children at recess.

For many children, school provides their only opportunity for engagement in physical activity, sports and play. This is particularly true of the children who are often otherwise excluded from participation. Schools also provide an excellent opportunity for whole communities to increase their physical activity levels.
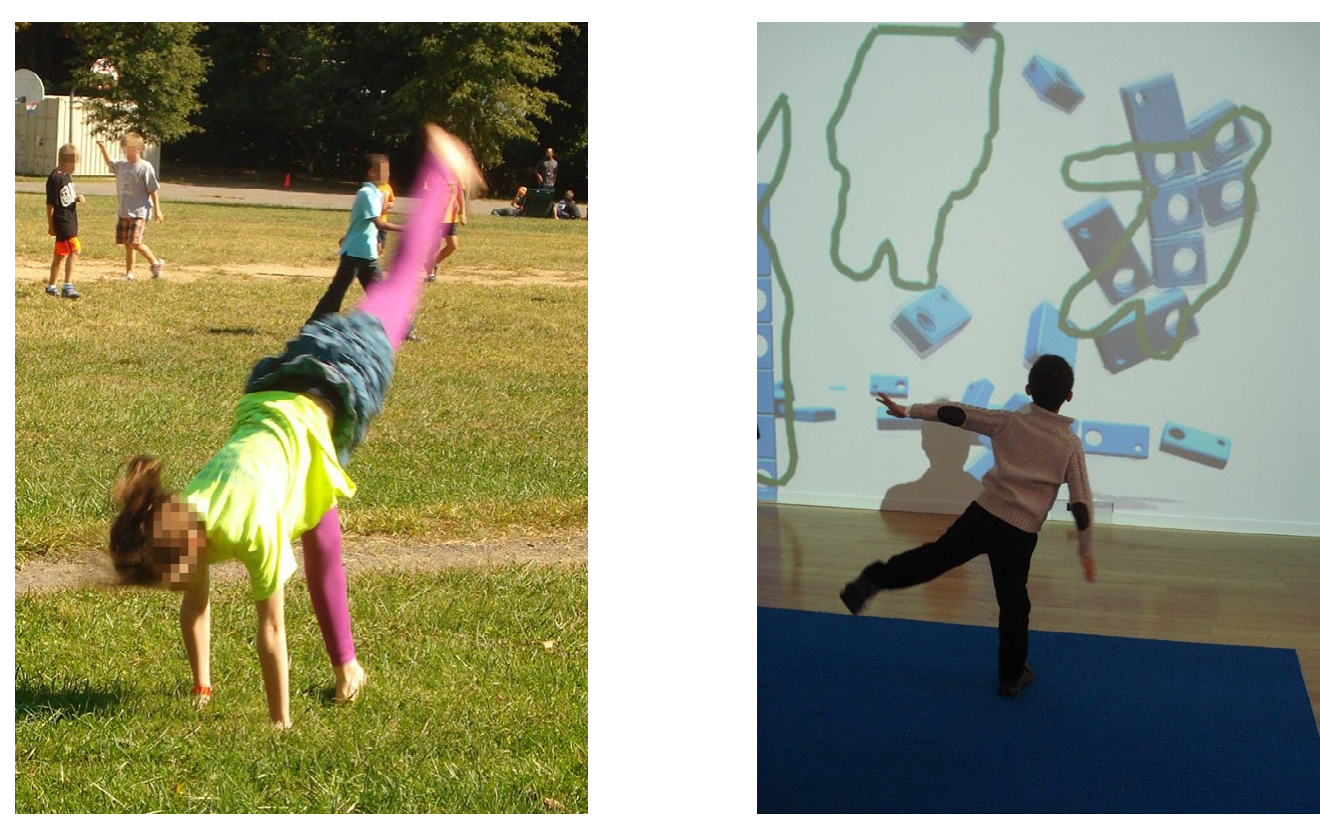

Figure 4.3 (left)

recess.

Figure 4.4 (right)

Interactive

digital display

of Imagination

of Imagination
Playground. 


\section{LeARNING Through PLAY}

There are four main components in a school setting that could be capitalized on to increase movement and play throughout the school day.

\section{Large Multi-purpose Spaces}

Spaces such as the cafeteria, gymnasium, roofs, and gathering spaces can be taken advantage of to increase play and movement.

\section{The Hallway}

Active learning can occur throughout the transition space of the school through texture, material, elevation change, and wall display.

\section{The Clasroom}

The desk and chair, along with the floor space and surrounding walls can be reinvented to allow children to learn while moving. Outdoor Learning

The outdoor environment can serve as both a play space and teaching tool for children.

ARGE MULTI-PURPOSE SPACES

Flat roofs can provide additional outdoor playing fields to allow for large group play and movement beyond the dedicated gymnasium space. Gyms need to provide more than court space. Change in material and elevation such as a climbing wall and cargo nets increase the development of a child's motor skills. Cafeterias can also incorporate changes in elevation through a series of ramps and stairs creating a large terraced space excellent for lectures during evening and weekend hours. Providing a large gathering space for multiple classes to gather is extremely important. This space can be dynamic by creating a series of stairs and climbing functions connecting the multiple levels of the school.

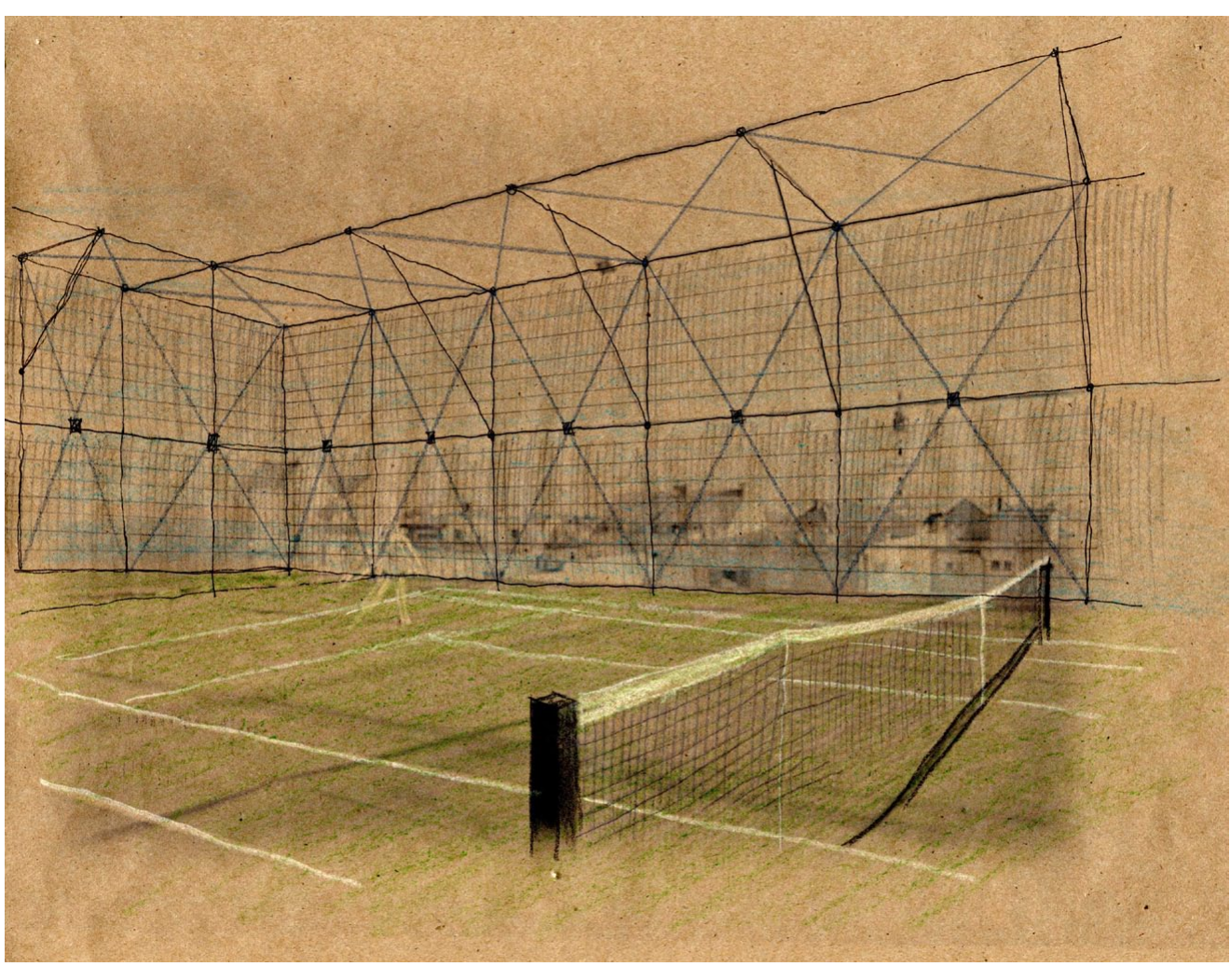

Figure 4.5

Roots can provide additional open

play fields.

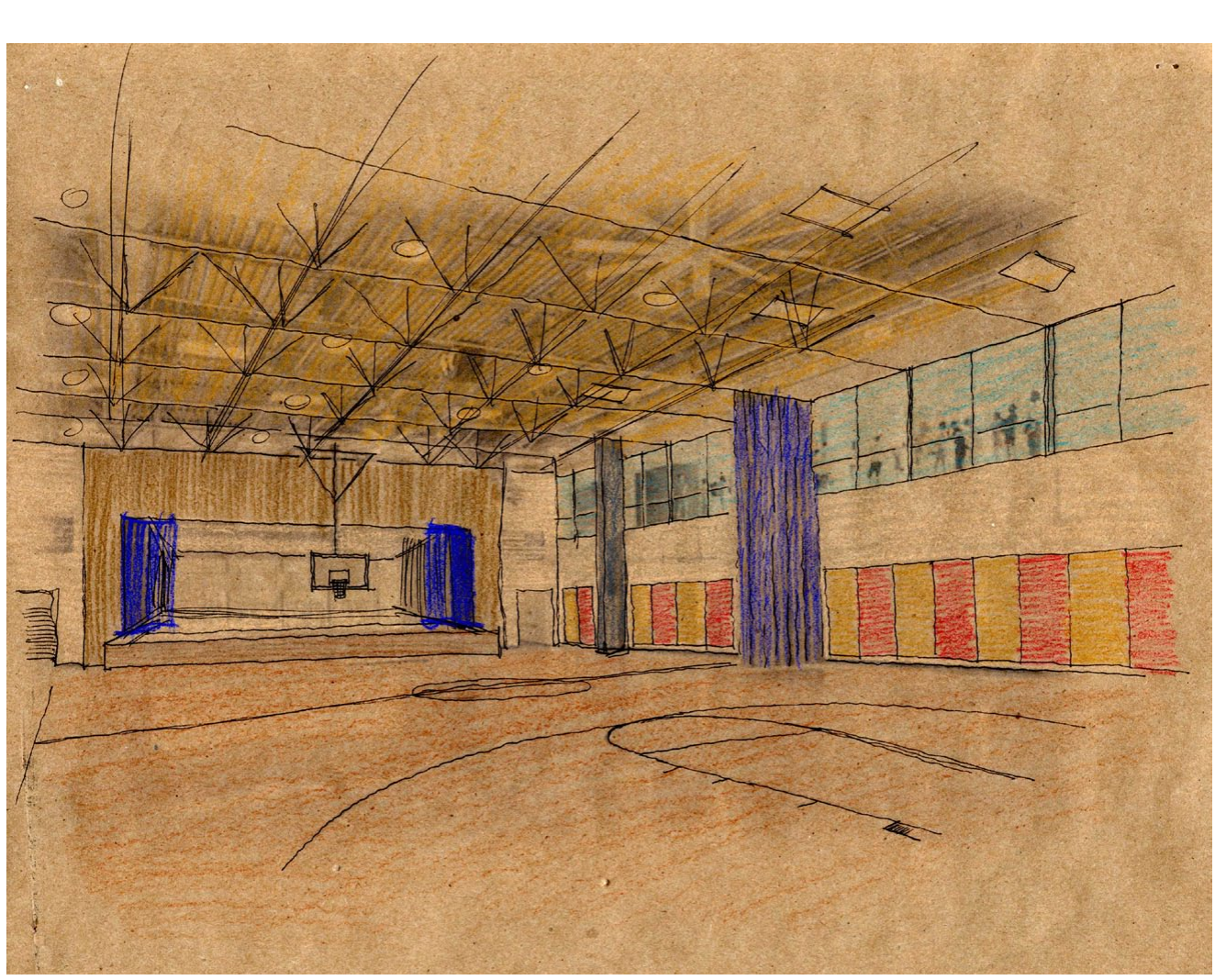

Figure 4.6

Gymnasiums can

develop children's fundamental

motor skills

through elements like climbing walls. 


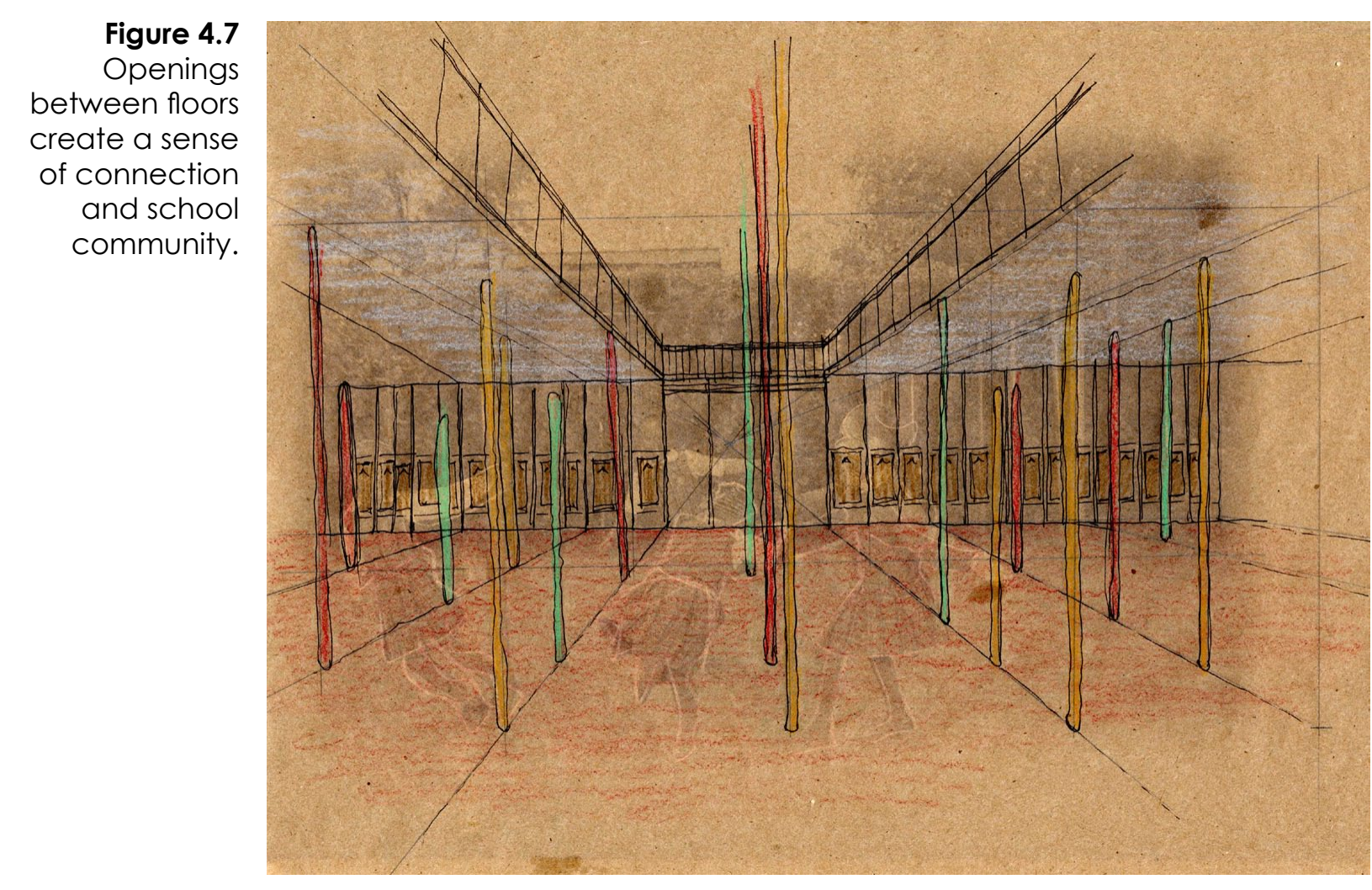

\section{THE HALLWAY}

A significant

percentage of a

child's time is spent

transitioning to and

from their homeroom.

The hallways have

the opportunity

to engage the

student in continual

learning through

the incorporation of

stairs, ramps, and wall

interactions. Visibility

to outdoor play and

Figure 4.8 sunlight from hallways The walls of the also increases a

hallway can serve child's positive spirit

as a constant to move and learn.

display of learning

through both

digital and printed

information.

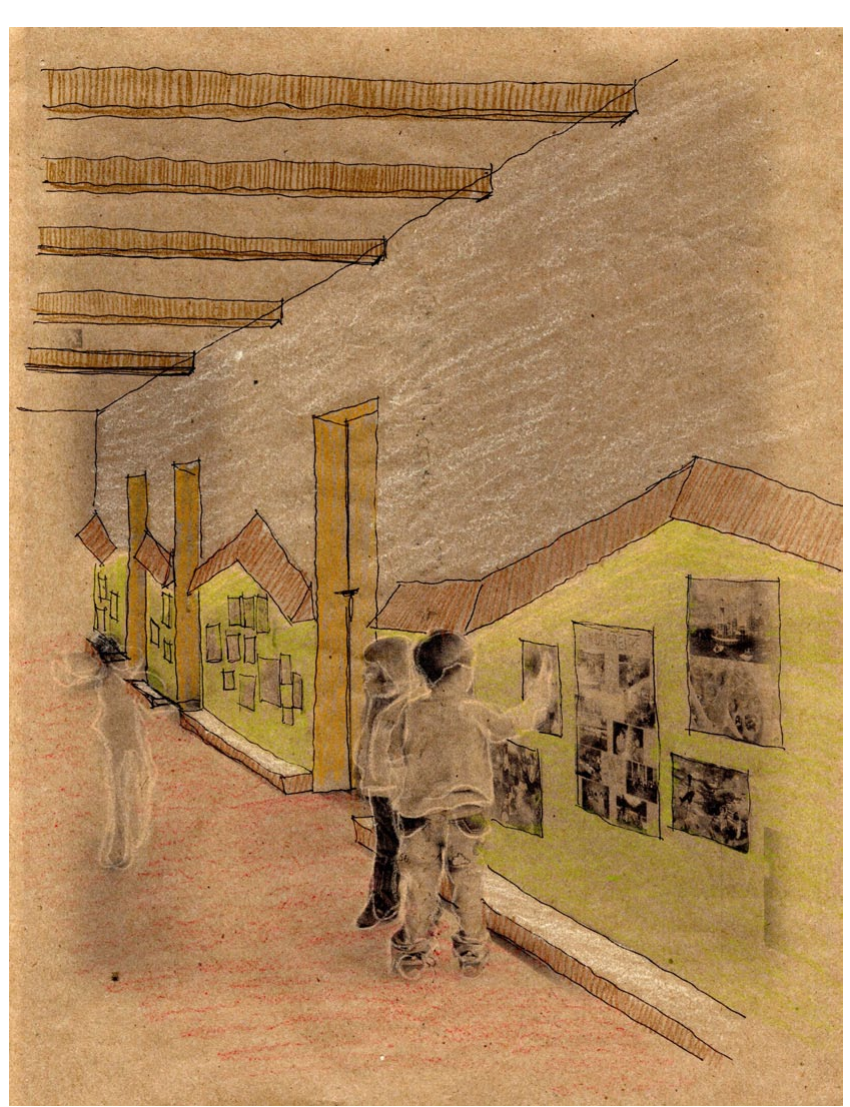

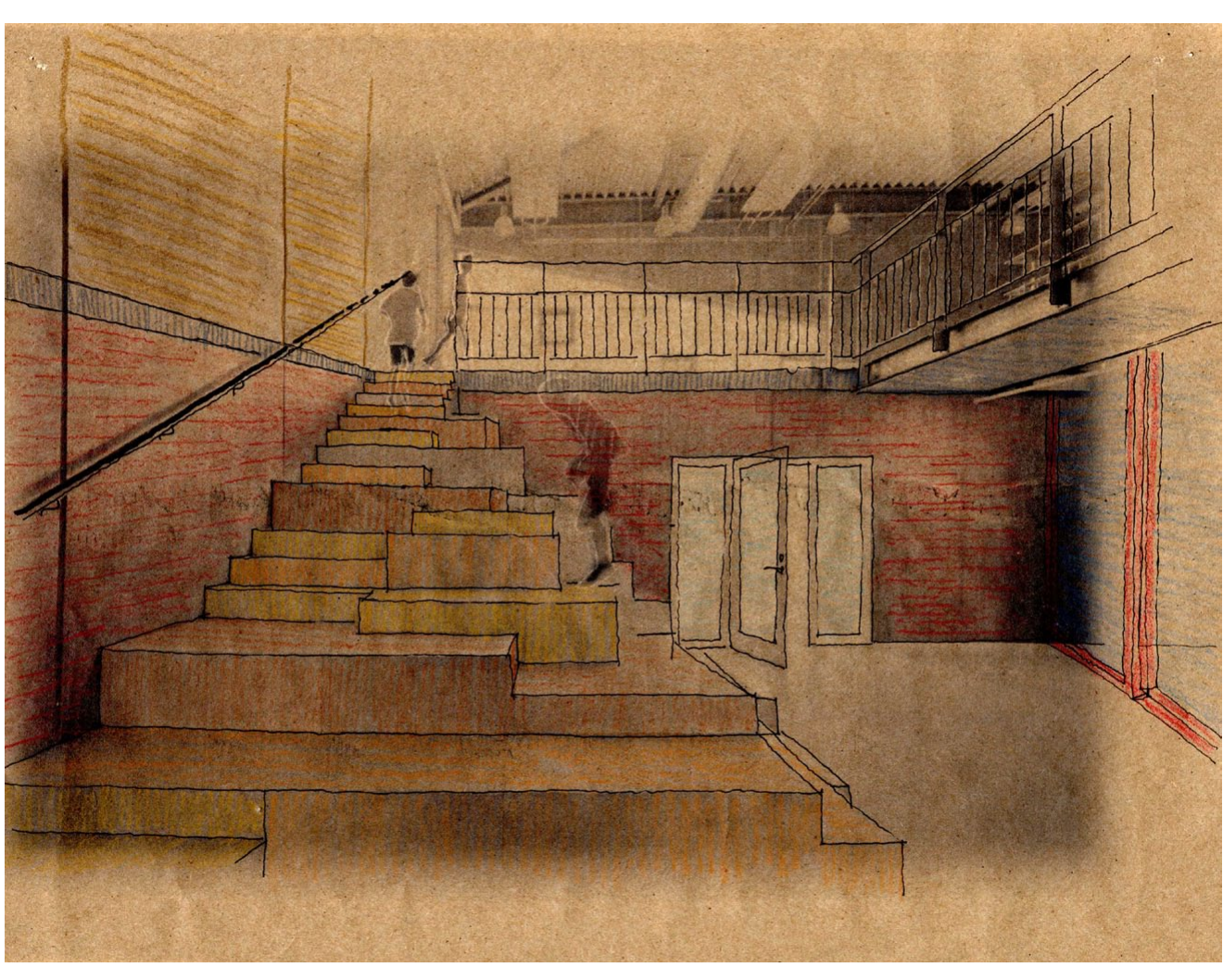

Figure 4.9

Variation in stair

rise and depth

increases a child's

motor skills while

also adding an

element of play.

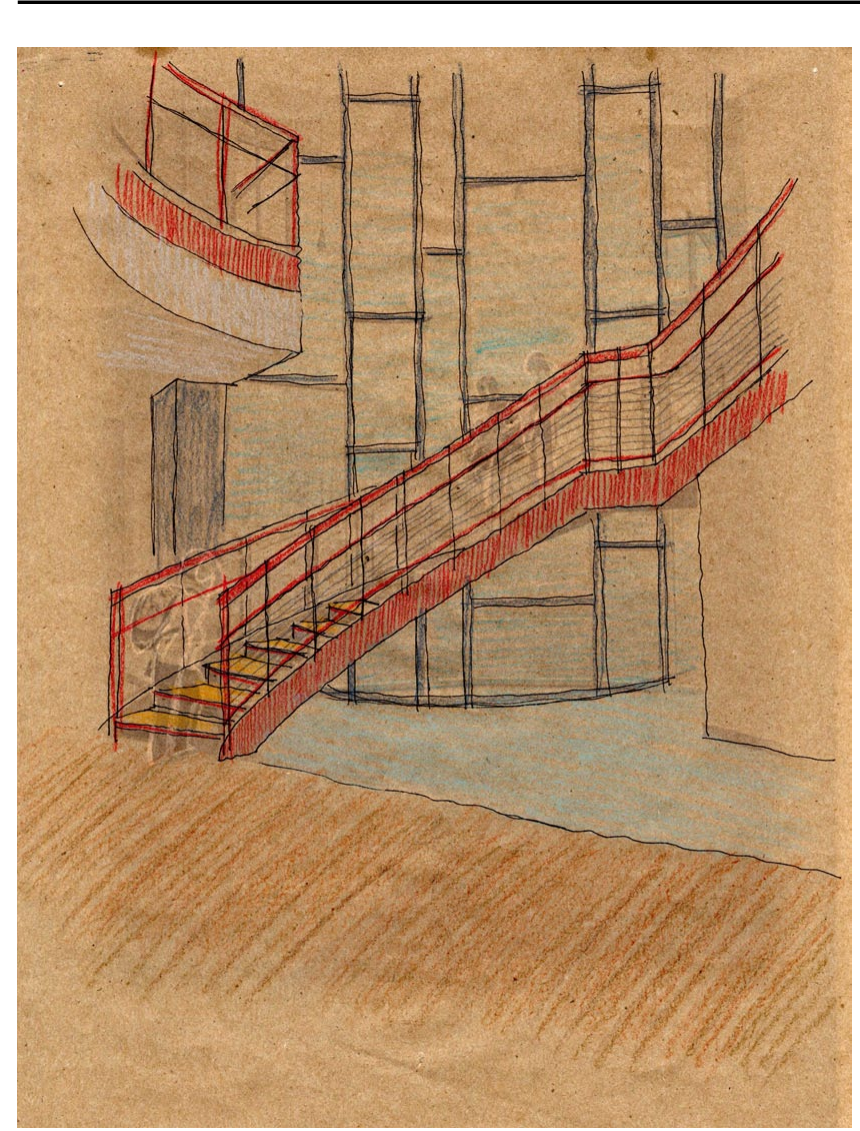

Figure 4.10

The hallway

should expose the

children to the

outdoors while

outdoors while
also providing

upper floors. 


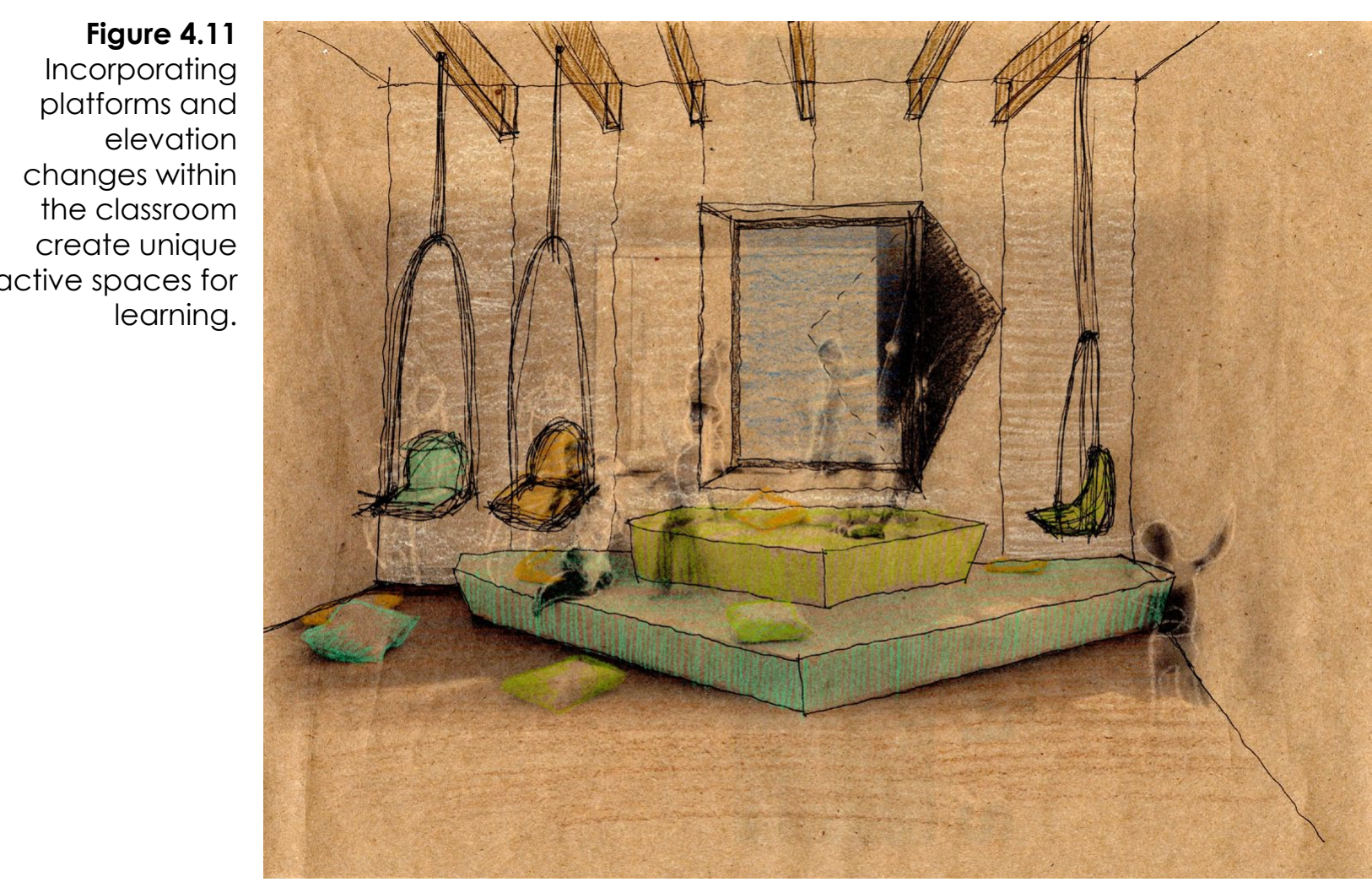

THE CLASSROOM Classrooms are the most visible symbol of a school for an elementary student.

It becomes their

second home and

should provide a

comfortable setting

to both move and

learn. Classrooms

should be flexible in

design so multiple

modes of learning

can take place.

Niches and cubbies

Figure 4.12 as well as open floor

Classrooms should accomodated within

be flexible with each classroom for

expand beyond flexible learning.

their four walls.

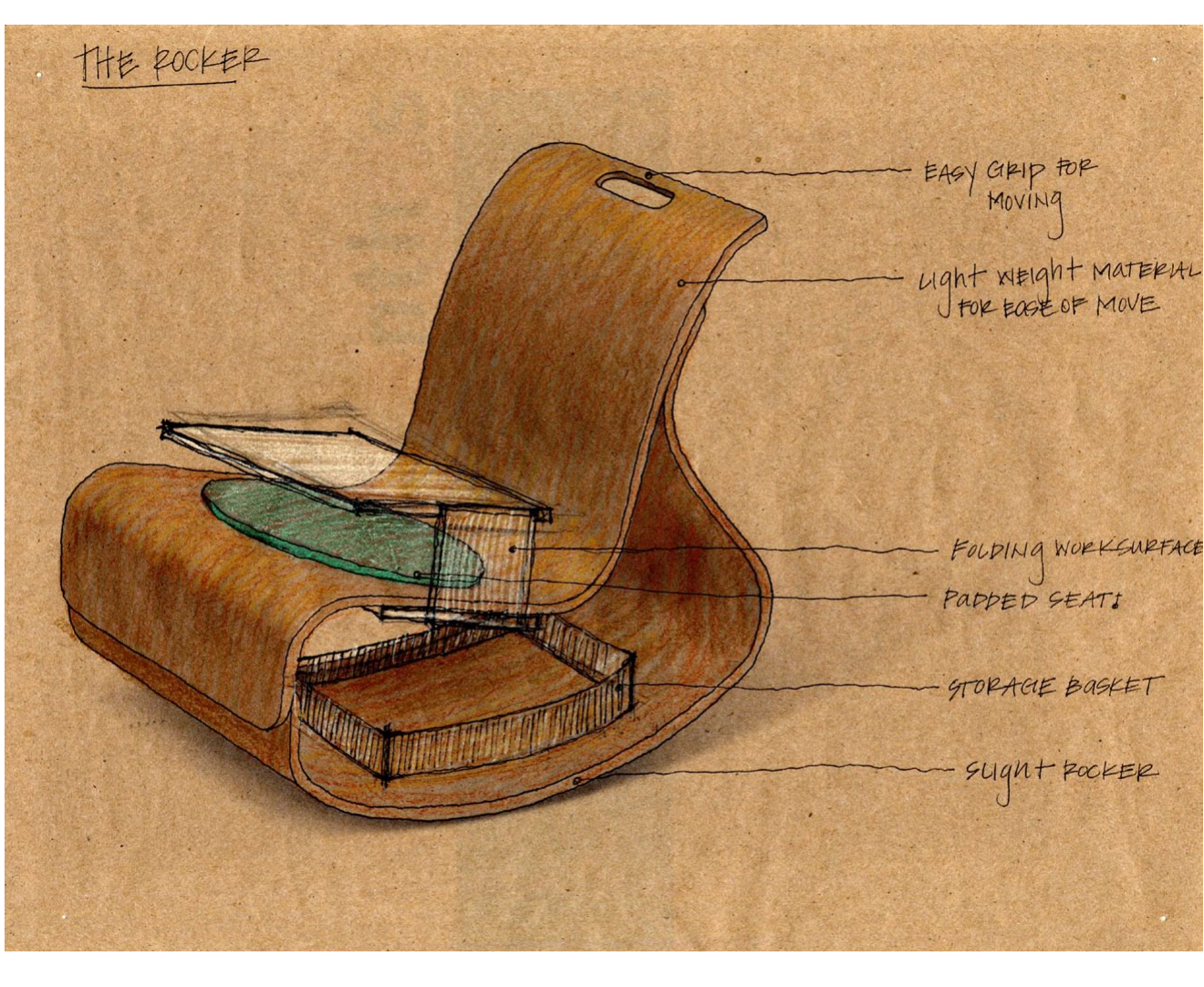

Figure 4.13

Rethinking the

design of the

"desk + chair"

could allow for

more movement

of the student.

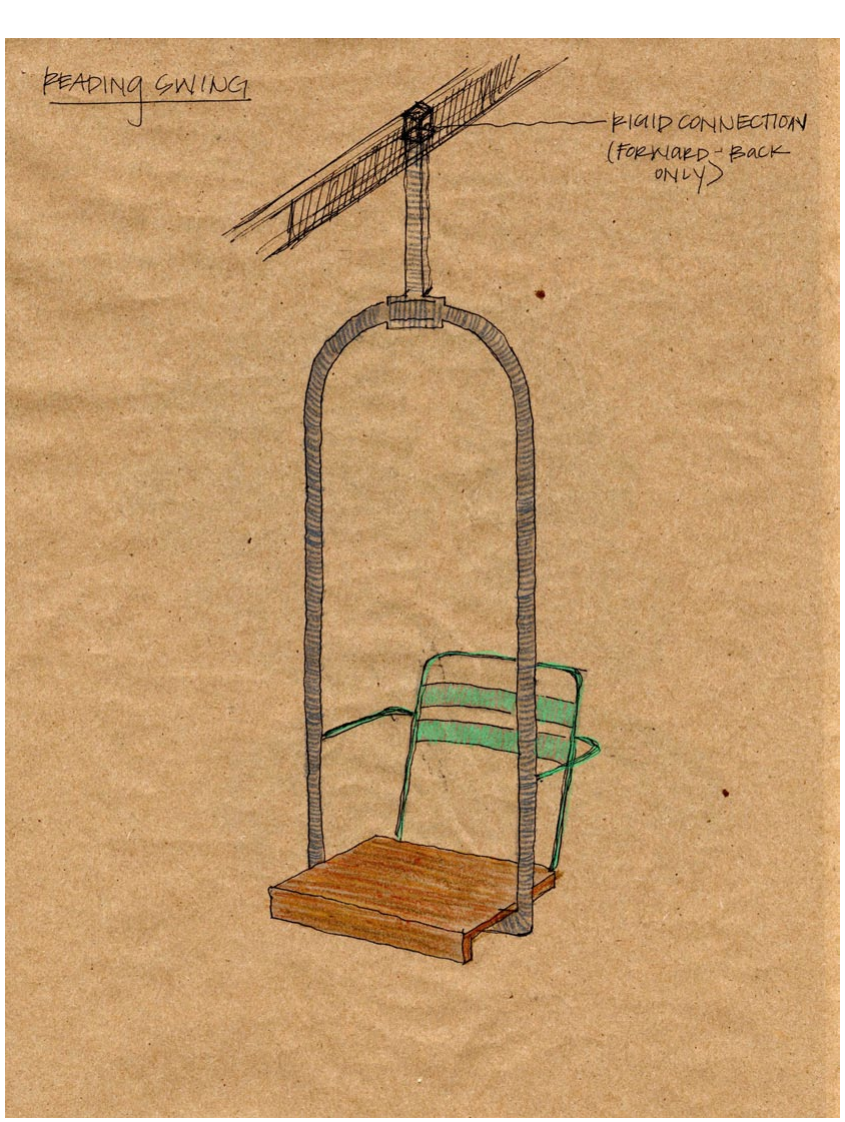

Figure 4.14

Swings within the classroom can

provide children the opportunity to move, and can be designed to retract into the ceiling increasing 

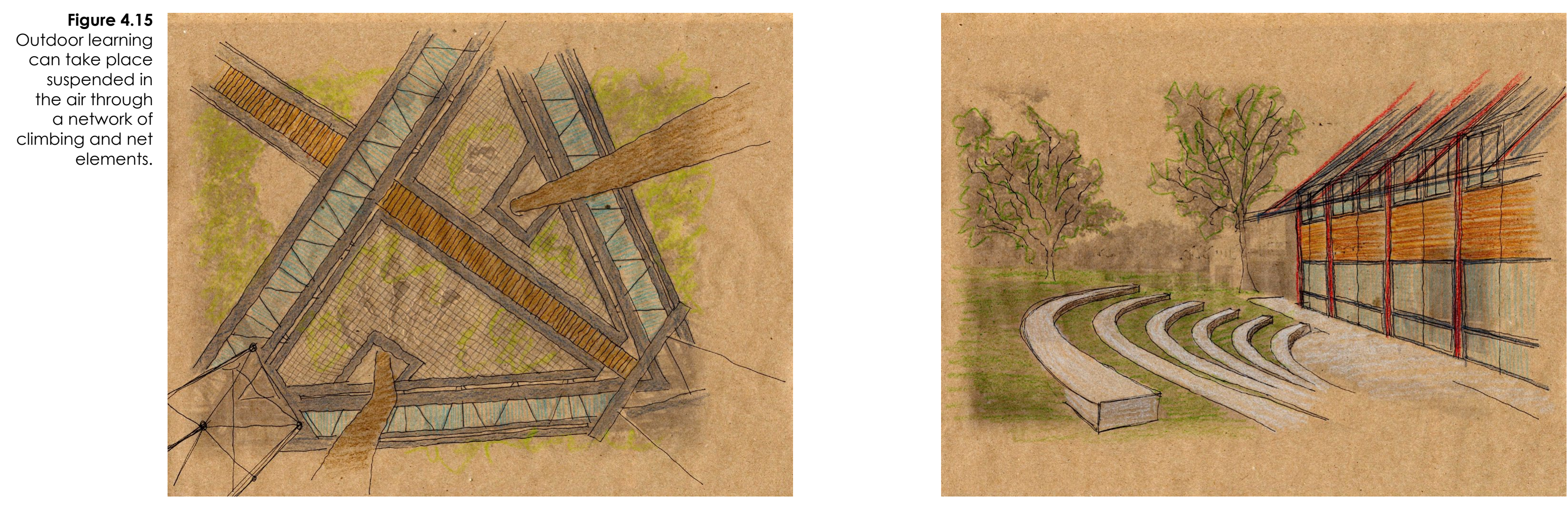

Figure 4.17

Outdoor learning

can happen in a

more organized

fashion through

a terraced

connected to the

media center.
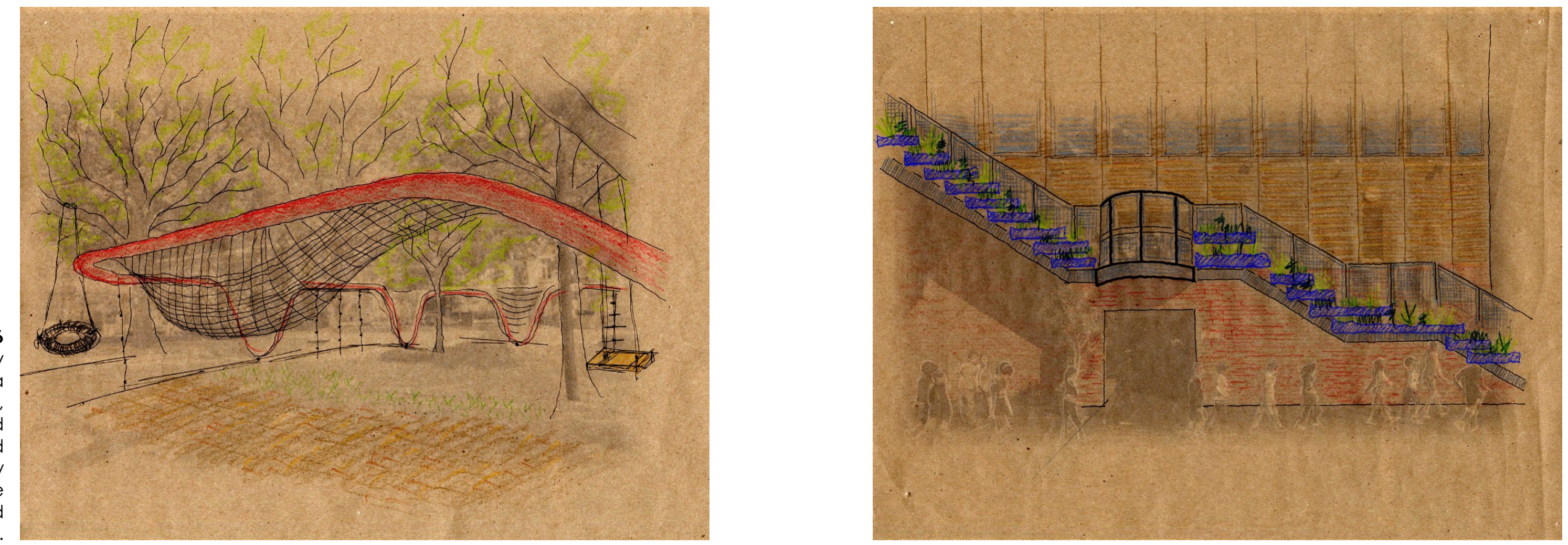

Figure 4.18

Gardens and

plants can

provide children

with hands-on

learning

experiences

outside the
classroom. 


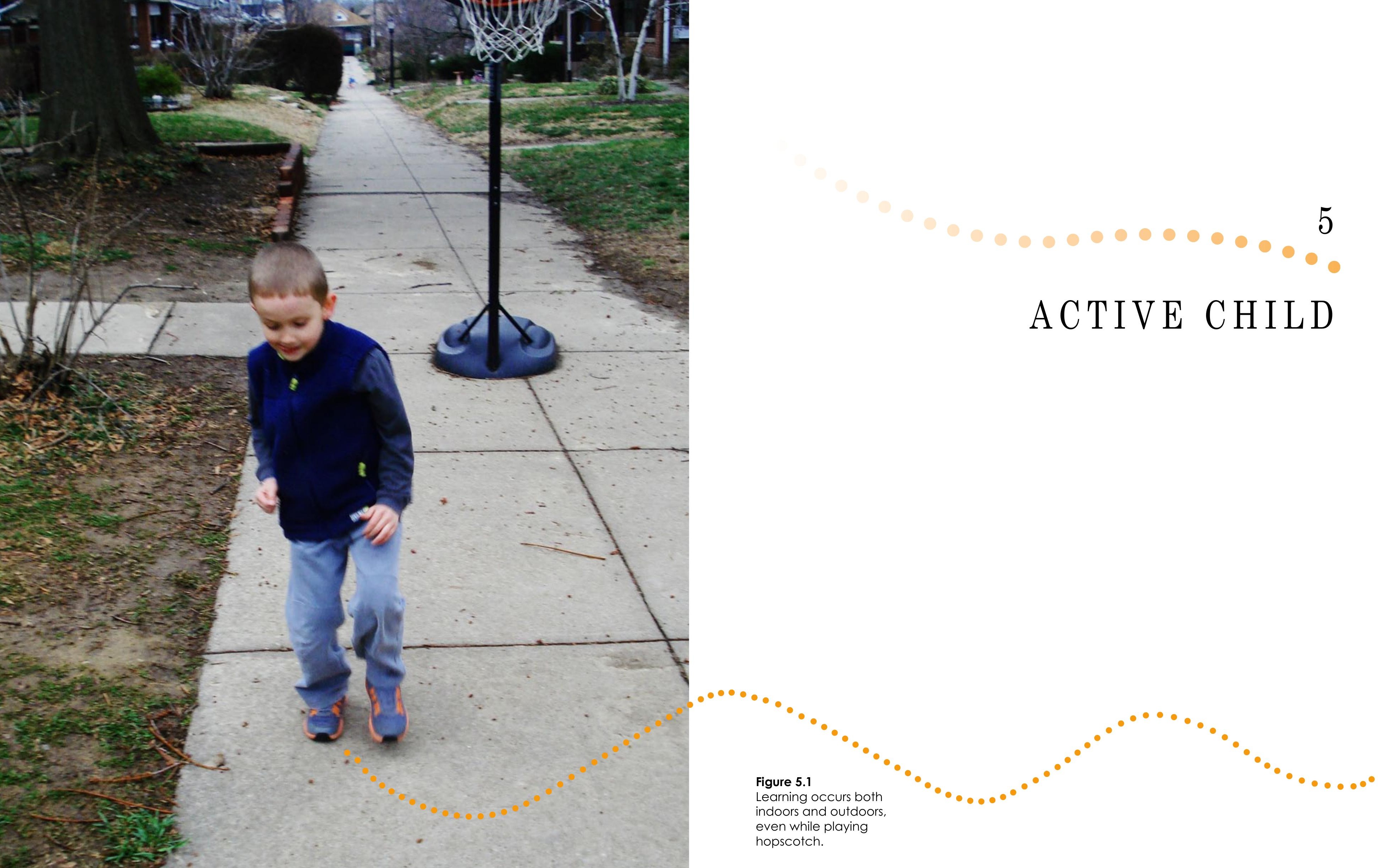




\section{PARKER-GRAY ELEMENTARY}

In addition to being a leading example in elementary teaching and learning methods, Parker-Gray Elementary School serves as a demonstration to the community on the importance for leading a healthy, active lifestyle. Both the interior and exterior of the school promote active learning through movement. Throughout the school grounds, students have the opportunity to learn through hands-on experiences. Students arrive at Parker-Gray every morning through many modes of transportation. Walking and biking to school are important methods of maintaining a healthy lifestyle. The urban environment around Parker-Gray is designed to encourage active forms of transportation through increased sidewalk widths, bike racks, and morning play in the courtyard.

A typical school day at Parker-Gray Elementary is best told by describing a student experience of learning through movement. While the school is meant to serve as a symbol to the whole community, first and foremost, the school must teach the students about leading a healthy and active lifestyle in a playful and educational manner.

Liam is a kindergarten student at Parker-Gray Elementary. He lives on the southern edge of the Potomac Yards development and during good weather walks, bikes or arrives to school on his scooter.

Figure 5.2

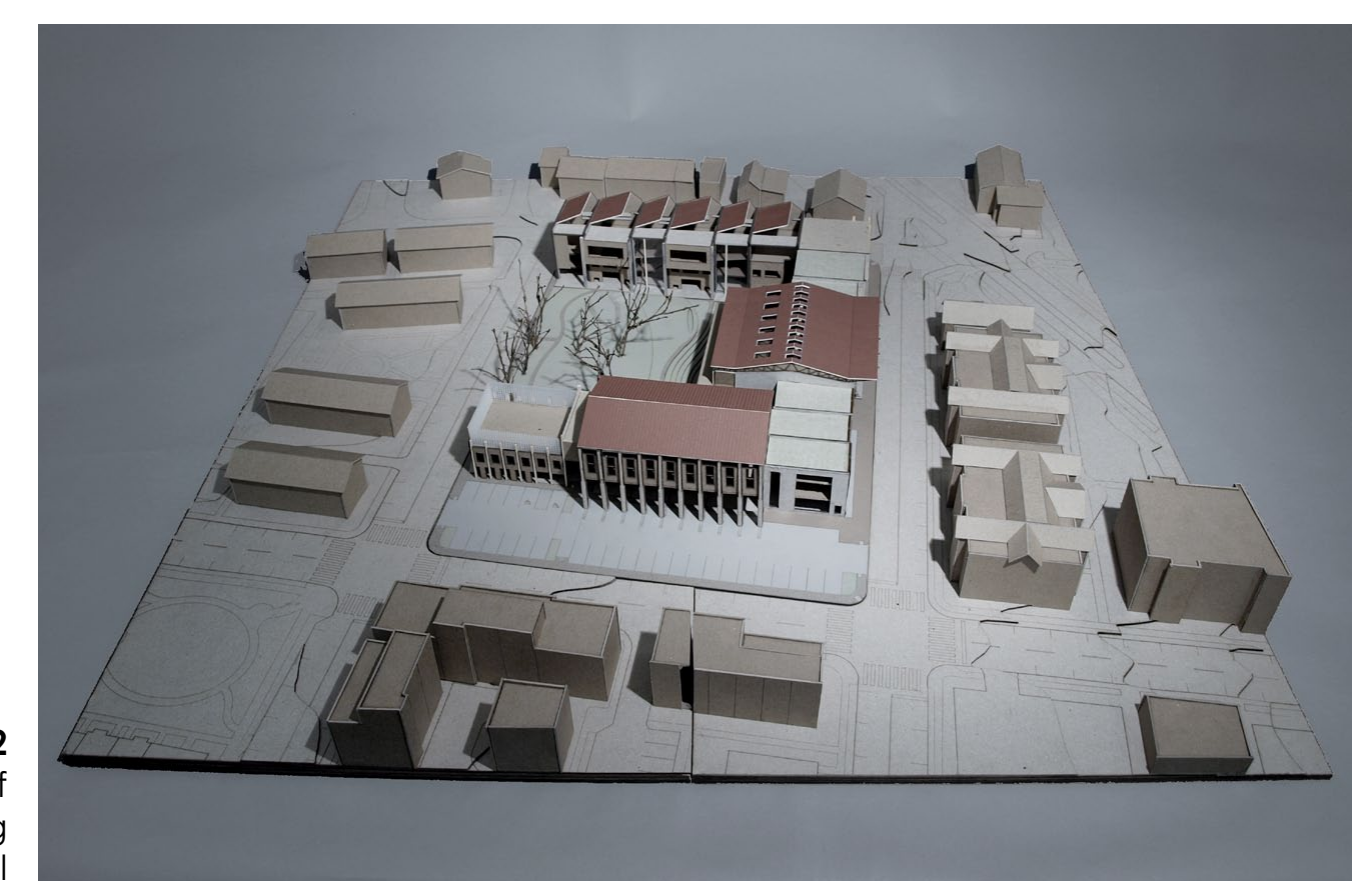

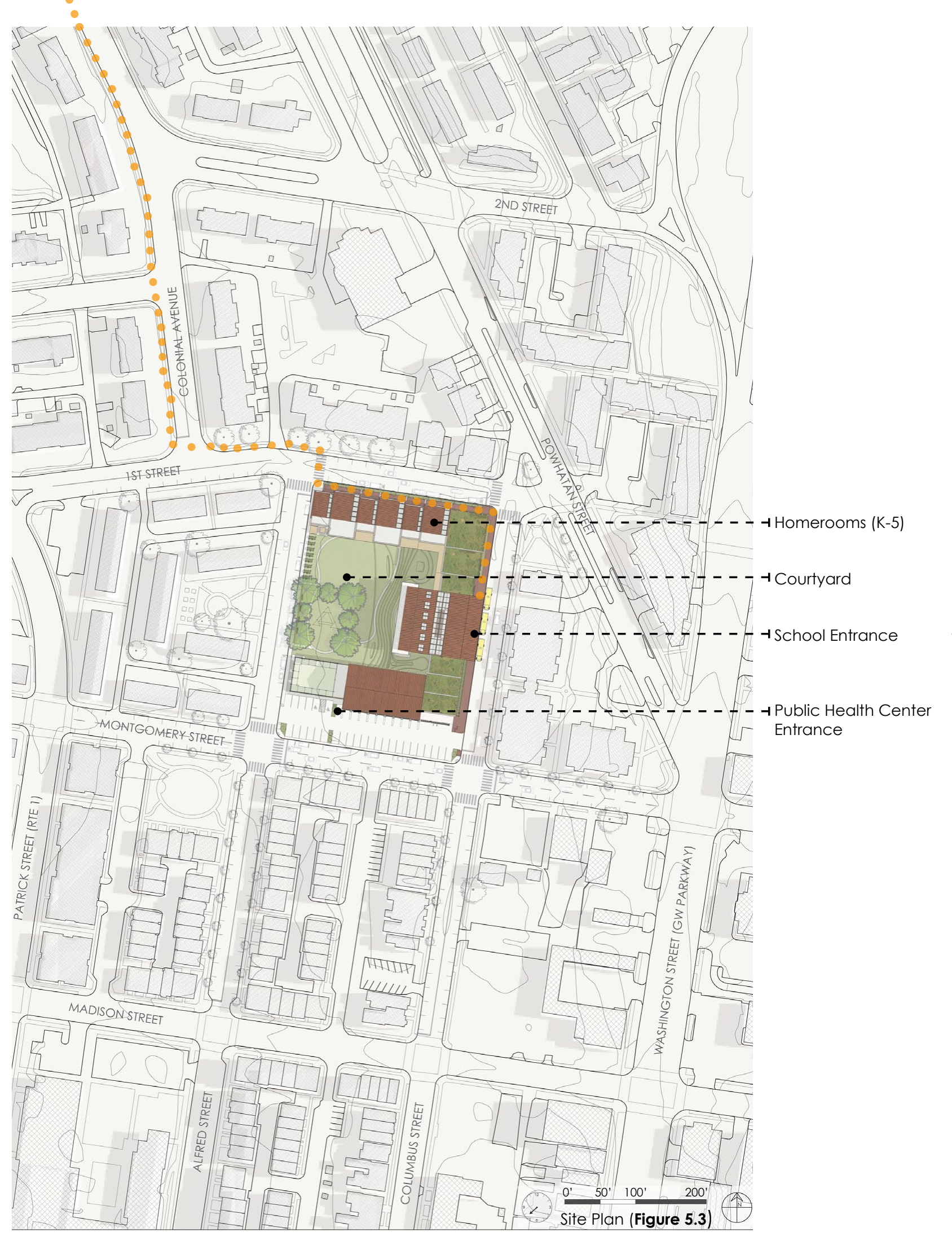

53 


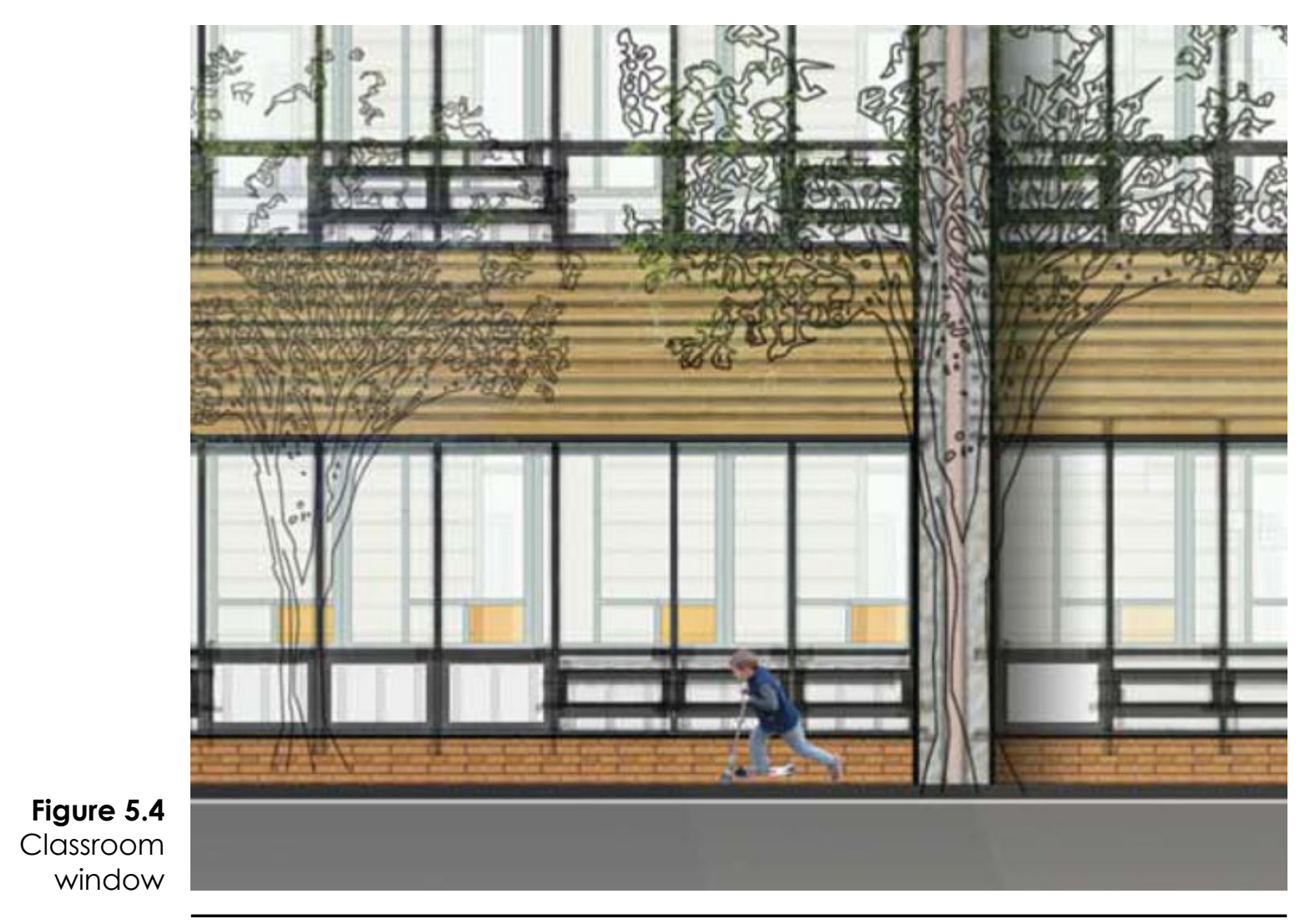

Liam scooters across the brick sidewalk along the north facade as he makes his way to the main entrance each morning. The classroom window heights are designed such that he is able to peer into his classroom on the ground level and see his classmates already arriving (Figure 5.4). Two-foot wide concrete walls divide the North Elevation into six individual "houses" creating a homelike identity for the students (Figure 5.5). At the intersection of the concrete walls and sidewalk, Liam is able to see a small trickle of water still crossing his path and into the integrated tree pit along the street edge that collects rain water from the roofs of the classrooms. The integrated tree pit serves as a rain garden and a teaching tool for the children while also keeping a significant portion of the run-off out of the courtyard, and out of the storm system.
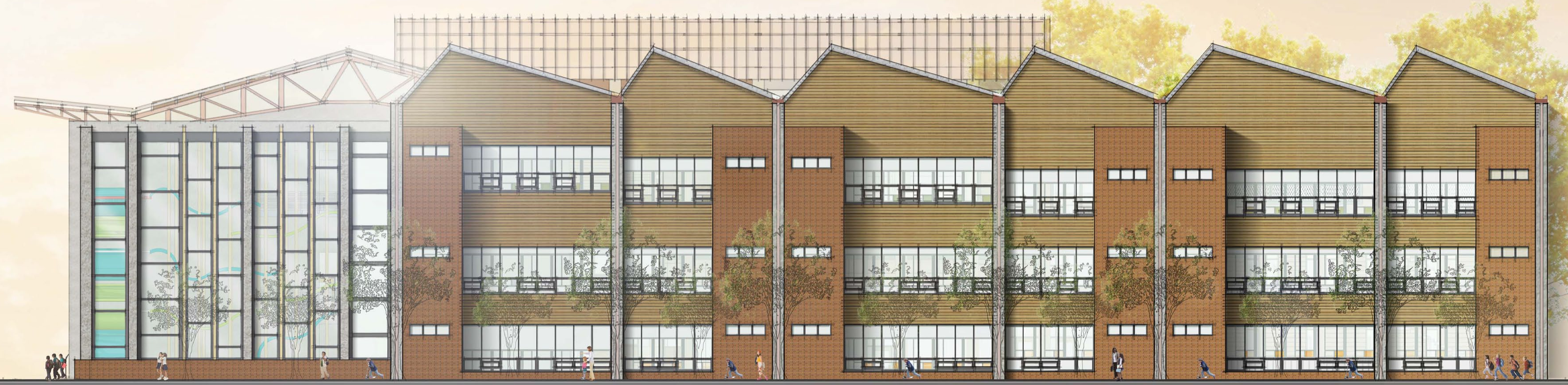


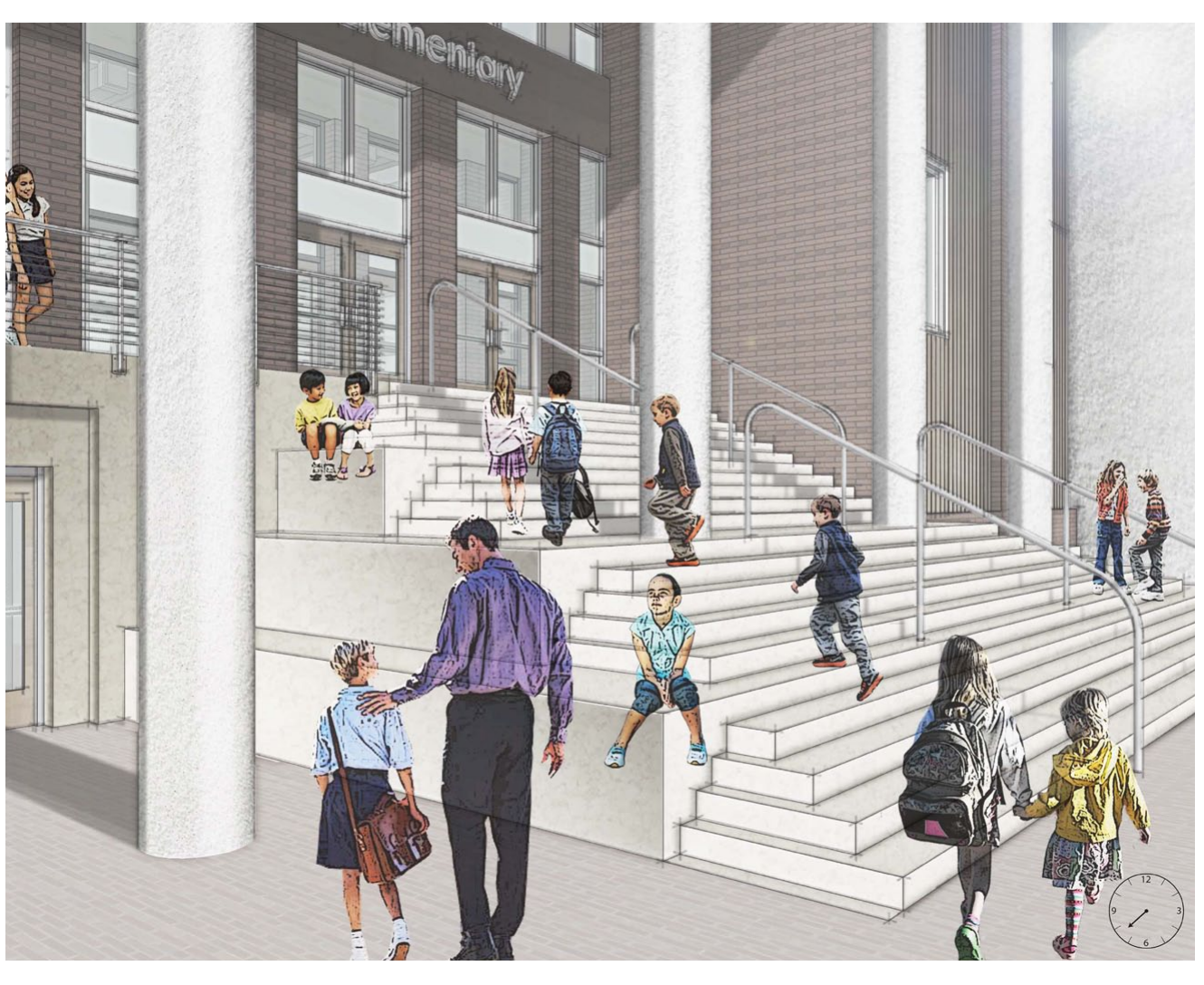

As Liam approaches the northeast corner of the school, he is able to peer into one of his favorite indoor spaces of the school - The Assembly Hall. To Liam, this corner of the school is the active zone they cross through on their way to speciality classes and lunch. To the community, this corner anchors the school and acts as a transition point by bringing the "playground" inside and allows viewers from the corner to a have a glimpse of the courtyard beyond. Liam makes his way to the east entry stair. Rising tenfeet in height, the entry stair immediately engages students in a playful and active approach to the front doors. The stairs vary in depth and height allowing for the student to creatively choose a new path each morning as they enter the school (Figure 5.6). The East Elevation merges the southern public zone of the school and the northern, private zone of the classrooms through its freestanding concrete columns supporting the three story truss and roof structure above(Figure 5.7).

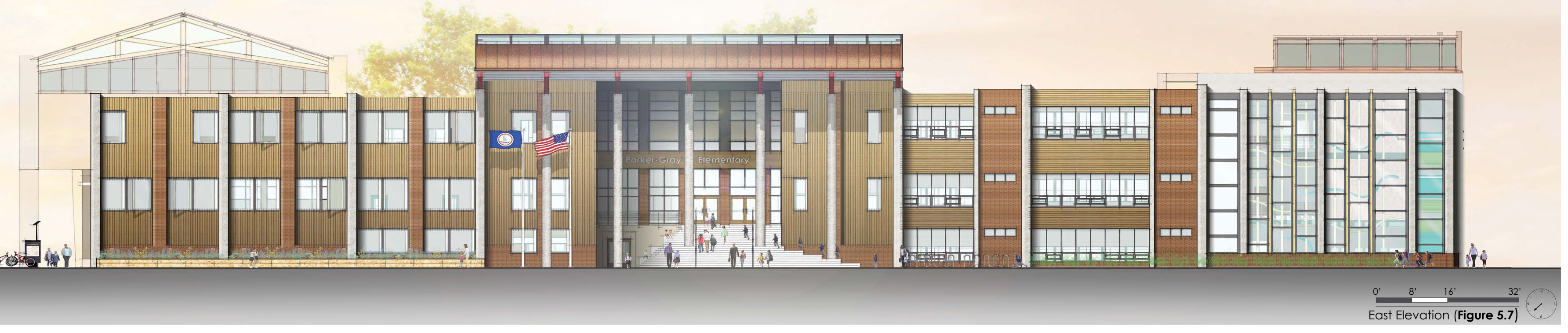


As Liam ascends the entry stairs, he arrives at school on the Main

Level (2nd level) of the building. He looks across the glass wall in front overlooking the two-story Library and into the courtyard. Eager to join his friends for their usual morning soccer game, he races down the hall to the north end of the building to find his classroom and drop off his bag.

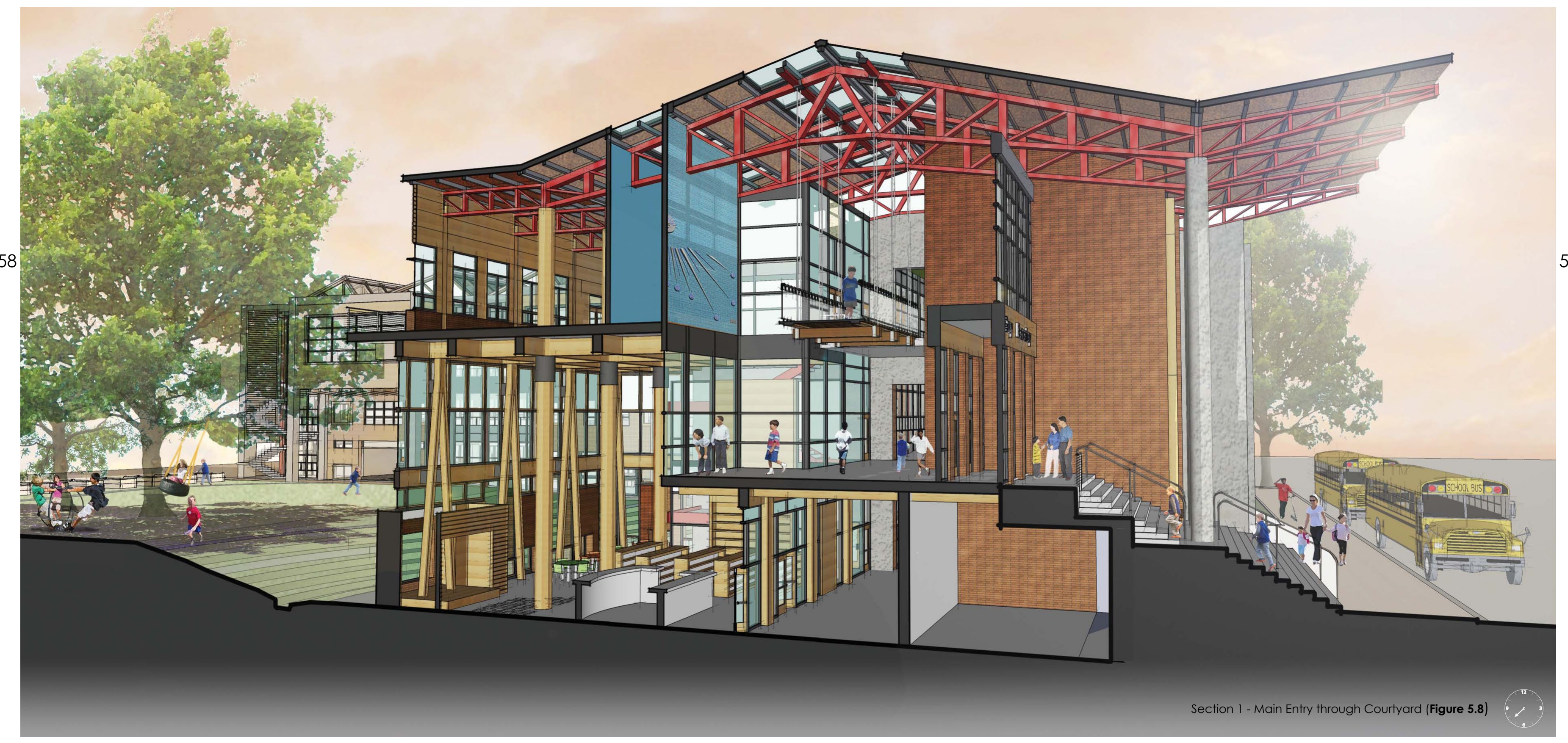




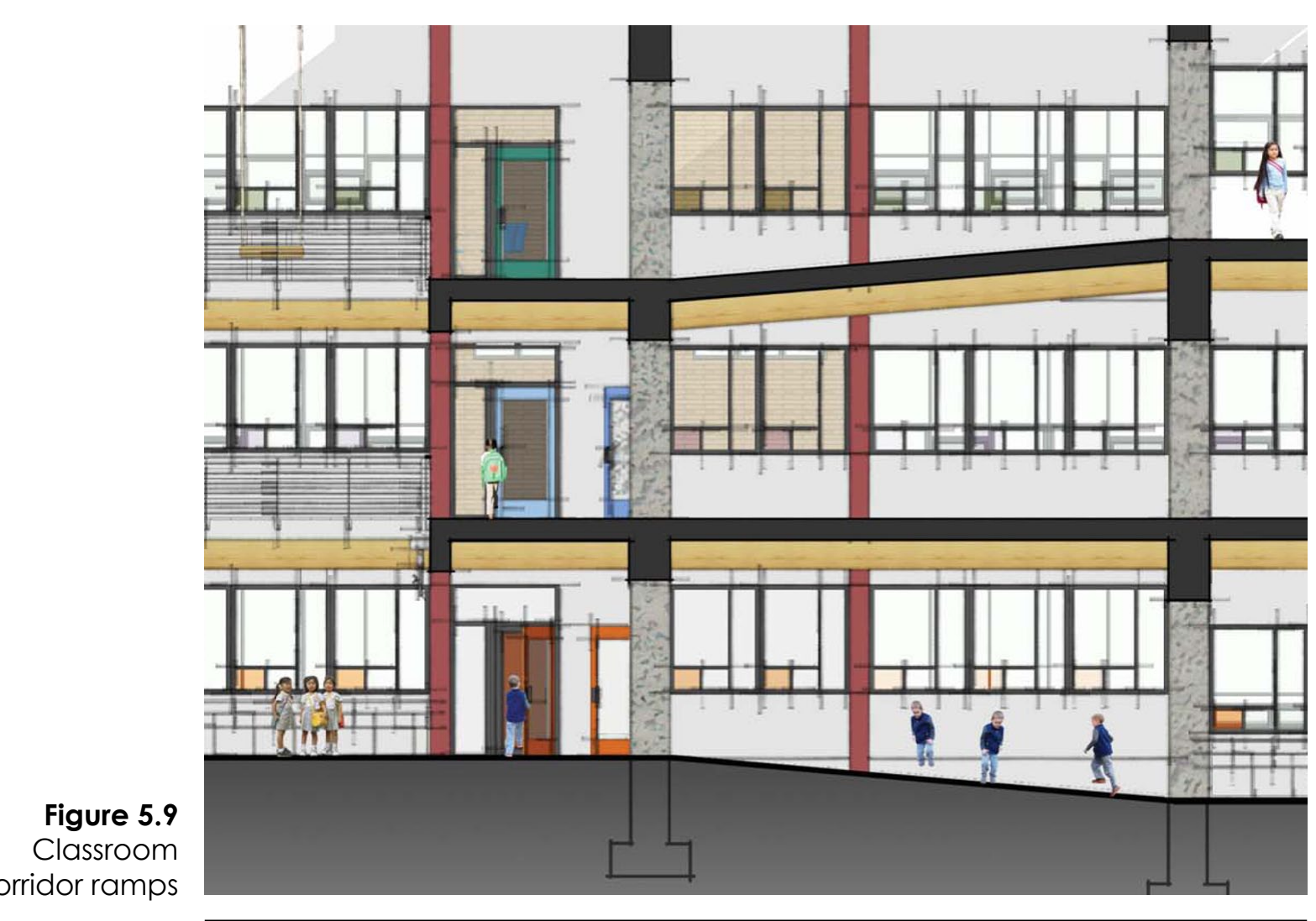

Liam reaches the northeast corner of the building, pausing for a few seconds to look for any friends in the The Assembly Hall before descending down the open stairs to his left finally reaching his floor - the courtyard level. Hopscotching across the series of ramps, he enters his homeroom (Figure 5.9). Wtihout looking up, Liam is aware that many students are arriving on the upper floors based on the voices traveling through the three-story opening. He quickly places his vest and backpack in his homeroom cubbie and races through the large garage door into the open field. Visibility from within the classrooms to the outside is important for the health and attitude of the students and teachers. Windows line the wall that is shared by the hallway and classroom creating a transport connection (Figure 5.10).
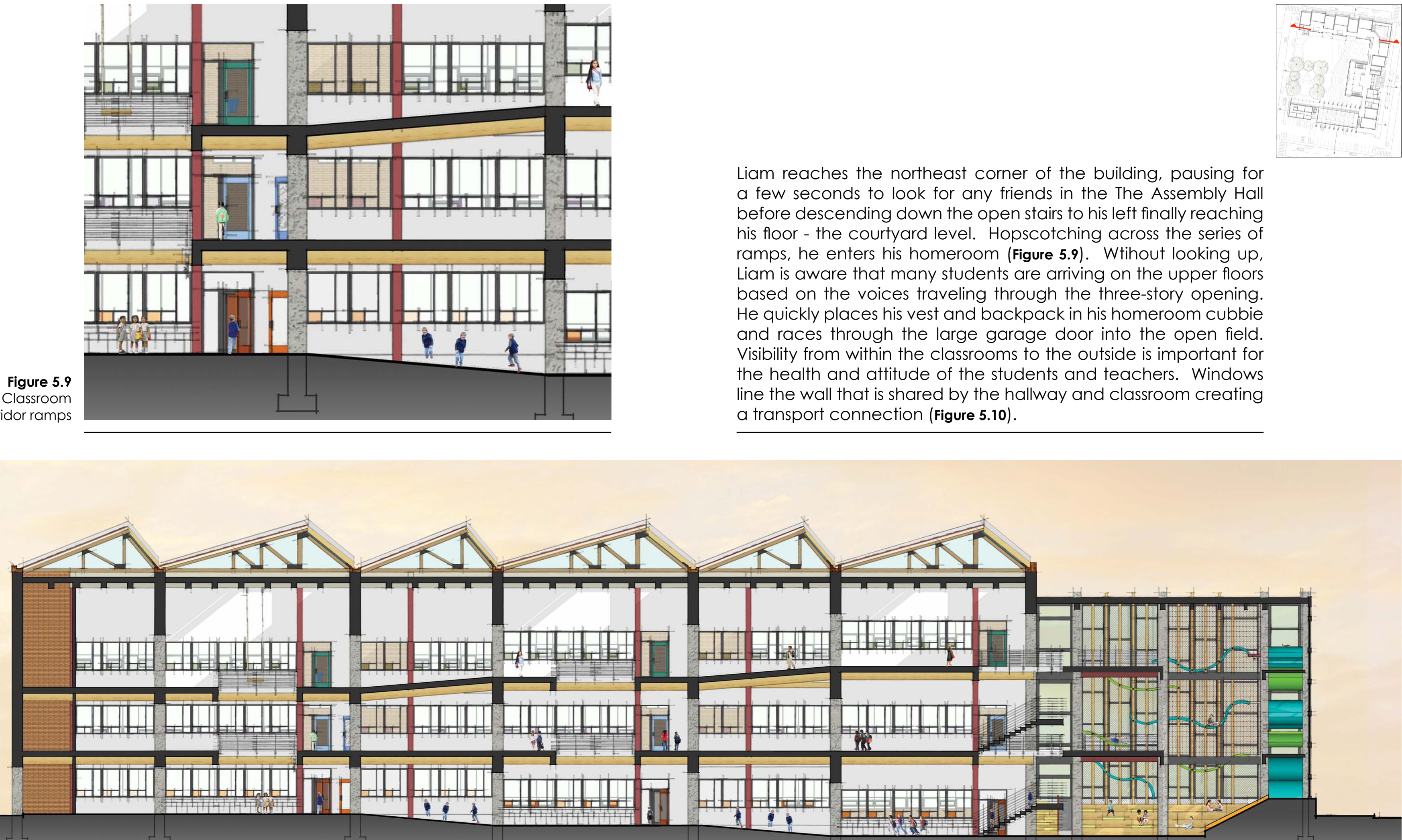
The Courtyard Level at Parker-Gray is where Liam and most Kindergarten and 1 st grade students spend the majority of their time. Six homerooms for kindergarten and 1st grade form the northern leg of the school with two classrooms turning the corne to start the transition from the small, intimate homerooms to large open spaces such as the library and cafeteria. On special days during morning reading time, Liam's class walks down to the Assembly Hall and spreads out across the platform stairs or finds their favorite spot in the climbing wall to read.

The school-based public Health Center has its own entrance at the south end of the building. Dental and mental-care offices along with exam rooms are located on the ground floor. During evening and weekend hours, visitors may enter through this south entrance for events in the cafeteria/multi-purpose room. This creates a secure entrance for visitors to access the public spaces at the south end of the school without disturbing the north end.

62

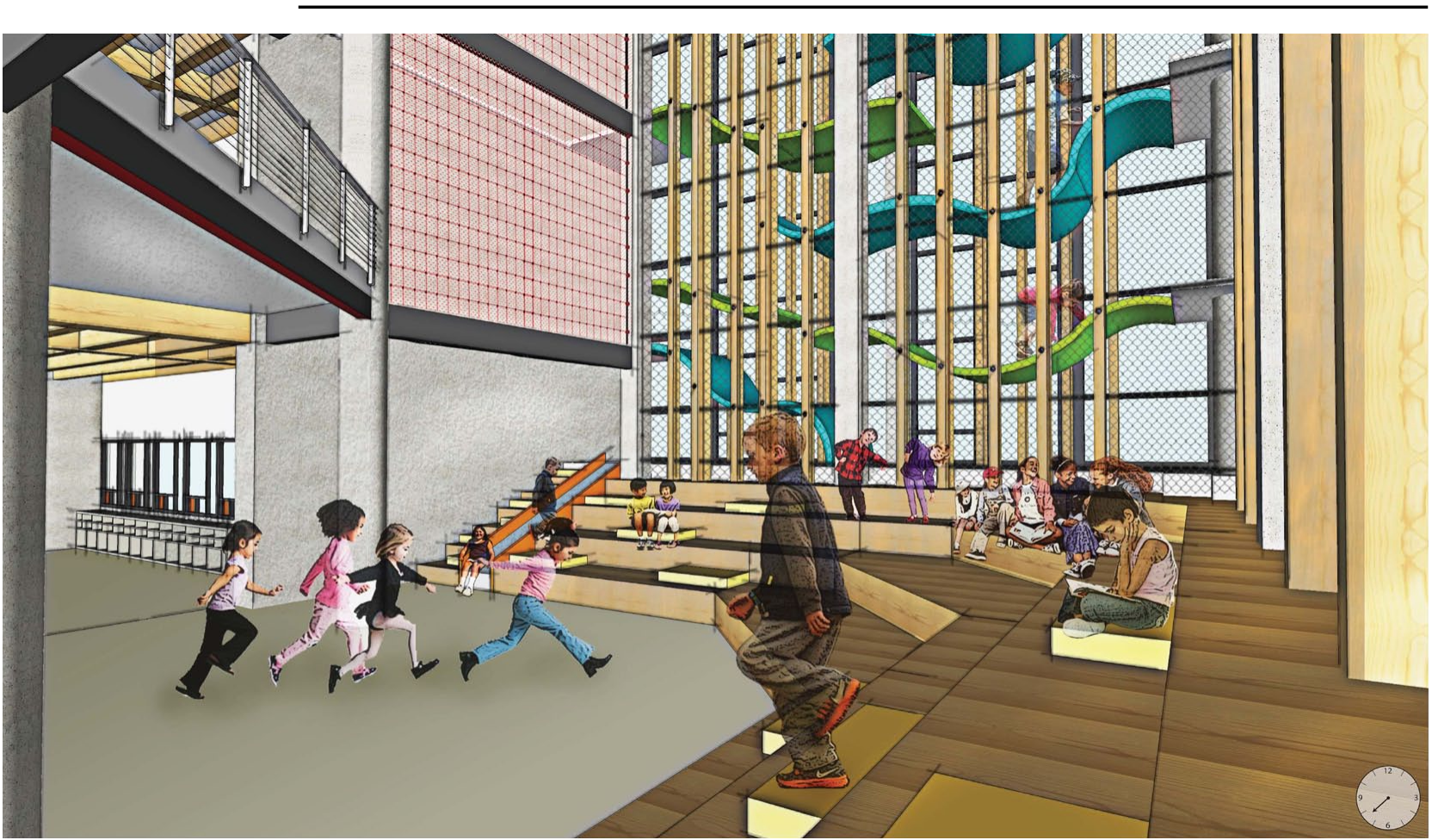

The Assembly Hall (Figure 5.11)

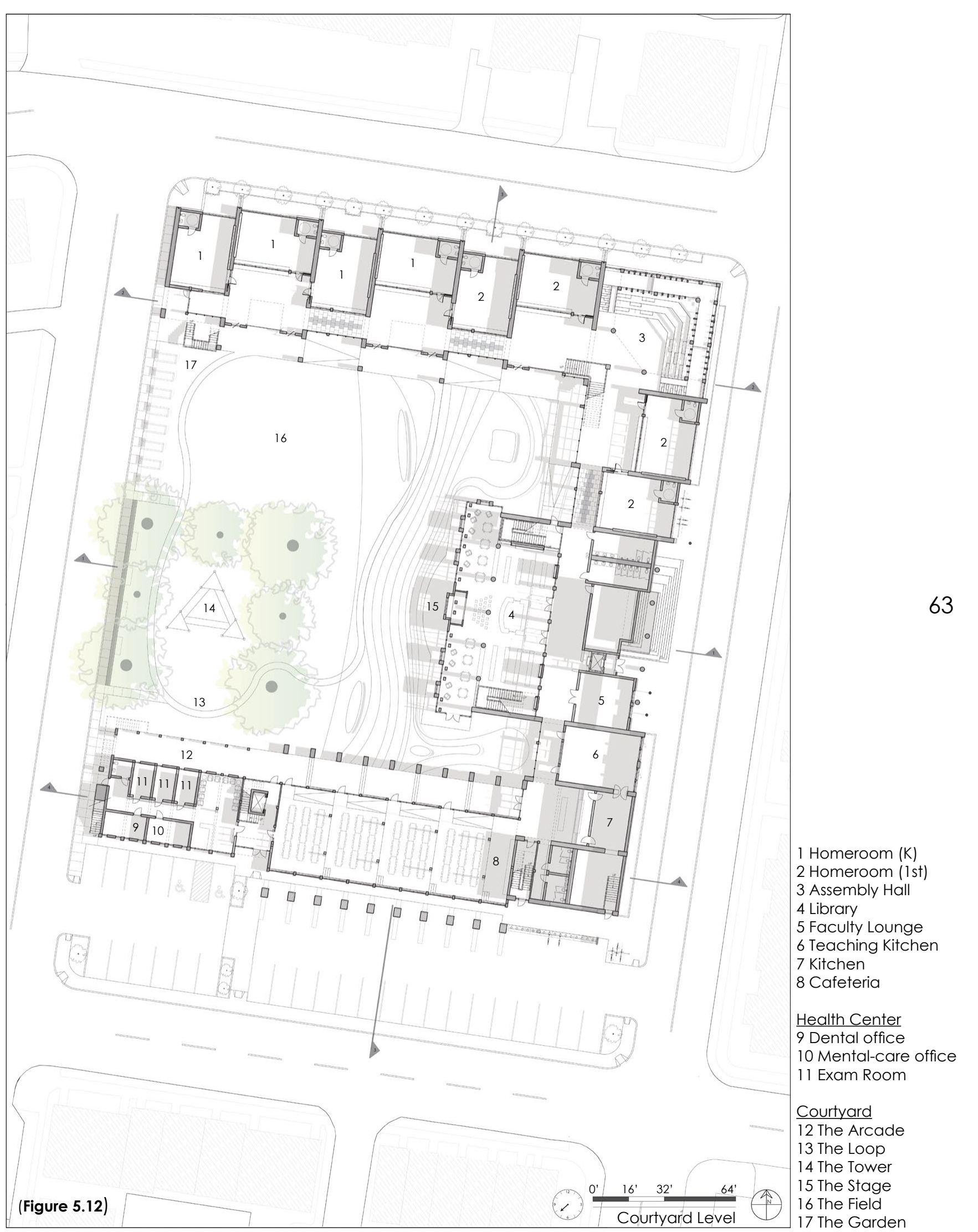


The Main Level is not only important for the 2nd and 3rd grade homerooms and science labs, but serves as a major transition floor between the north and south end of the school. The Assembly Hall climbing wall is an active floor that allows students to remain on the same level or provides the opportunity to climb to the upper floor to access art, music or gym class as well as descend down the wall for lunch and recess.

The second floor of the Health Center houses the physical health component with offices and fitness labs. During the day, students can access this level of the Health Center either from the cafeteria (courtyard level) or the gymnasium (upper level).

64

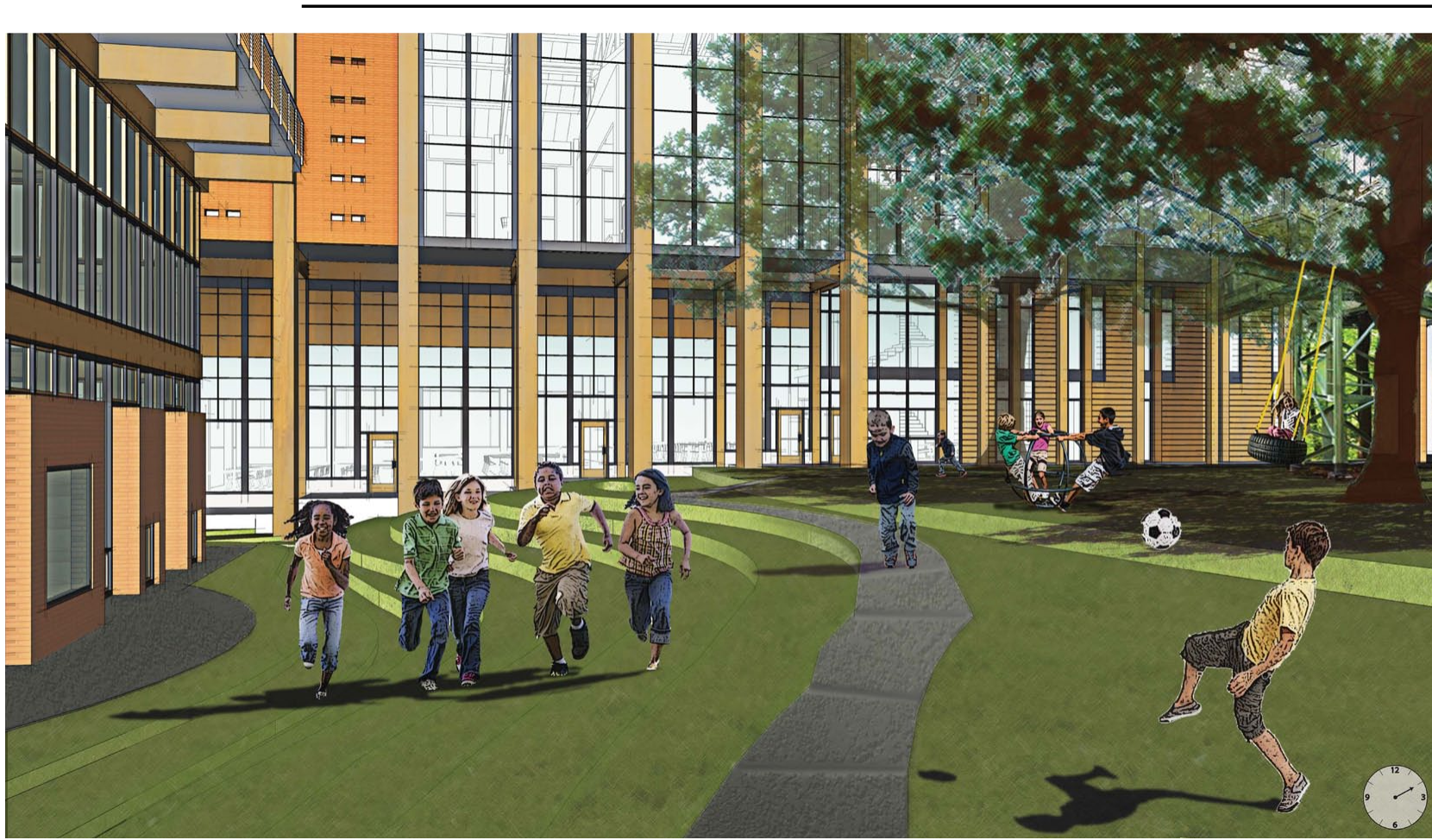

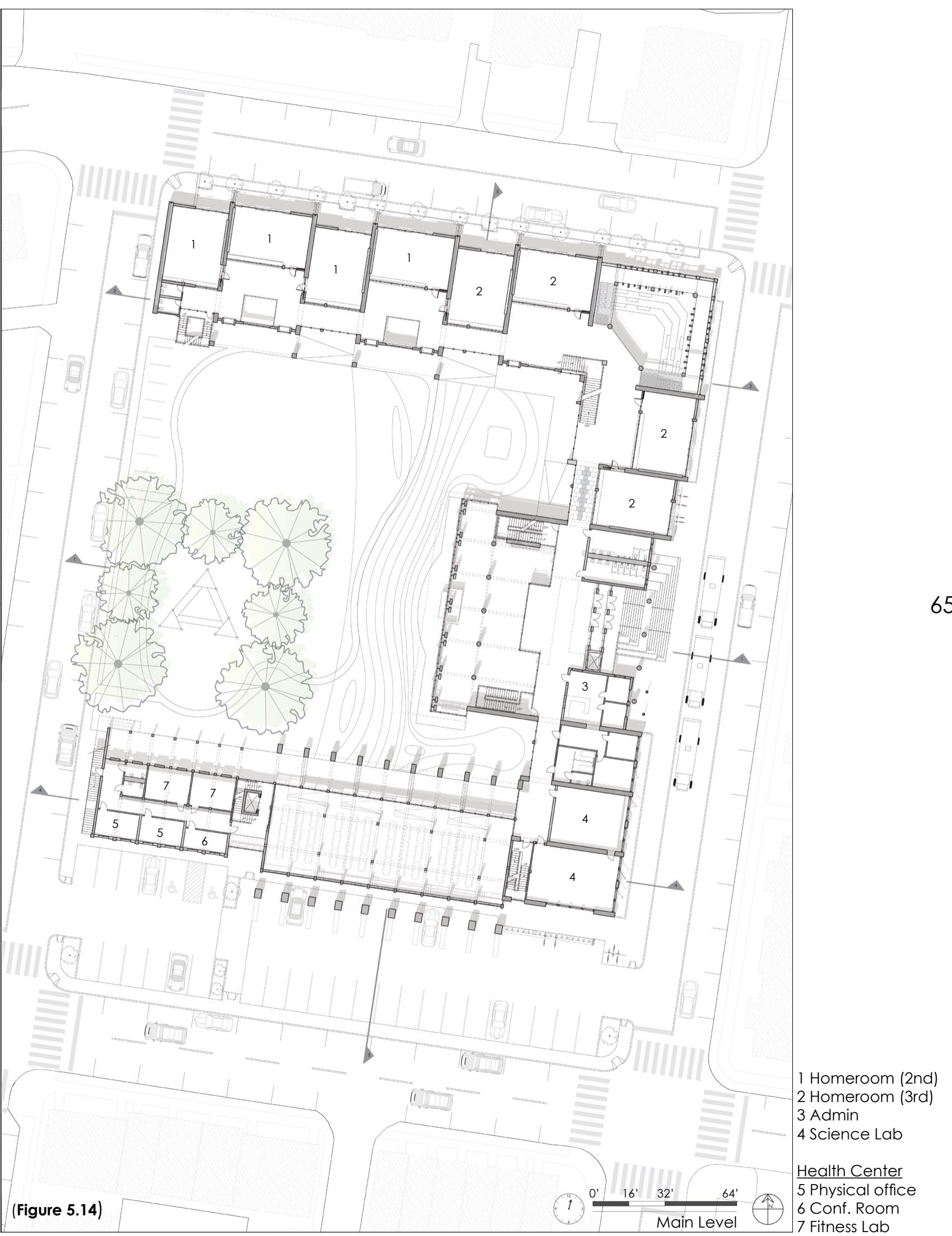


The afternoon for Liam is one of his favorite times. His daily math lesson has ended and his teacher has allowed for a few extra minutes for the students to travel to gym class on the Upper Level. Extra time to the students means they get to climb from the courtyard level of their homerooms up the Assembly Hall climbing wall to the top floor. Once the whole class reaches the Upper Level they travel across the suspension bridge over the main entry passing by the art rooms and music rooms ending at gym class.

This area is quite familiar to Liam and many students. Although it' used for gym class during the school day, organized basketbal games are played here on the weekends. When Liam's family has a few extra hours on the weekends they often walk down to Parker-Gray and play on the roof-top playing field adjacent to the gym

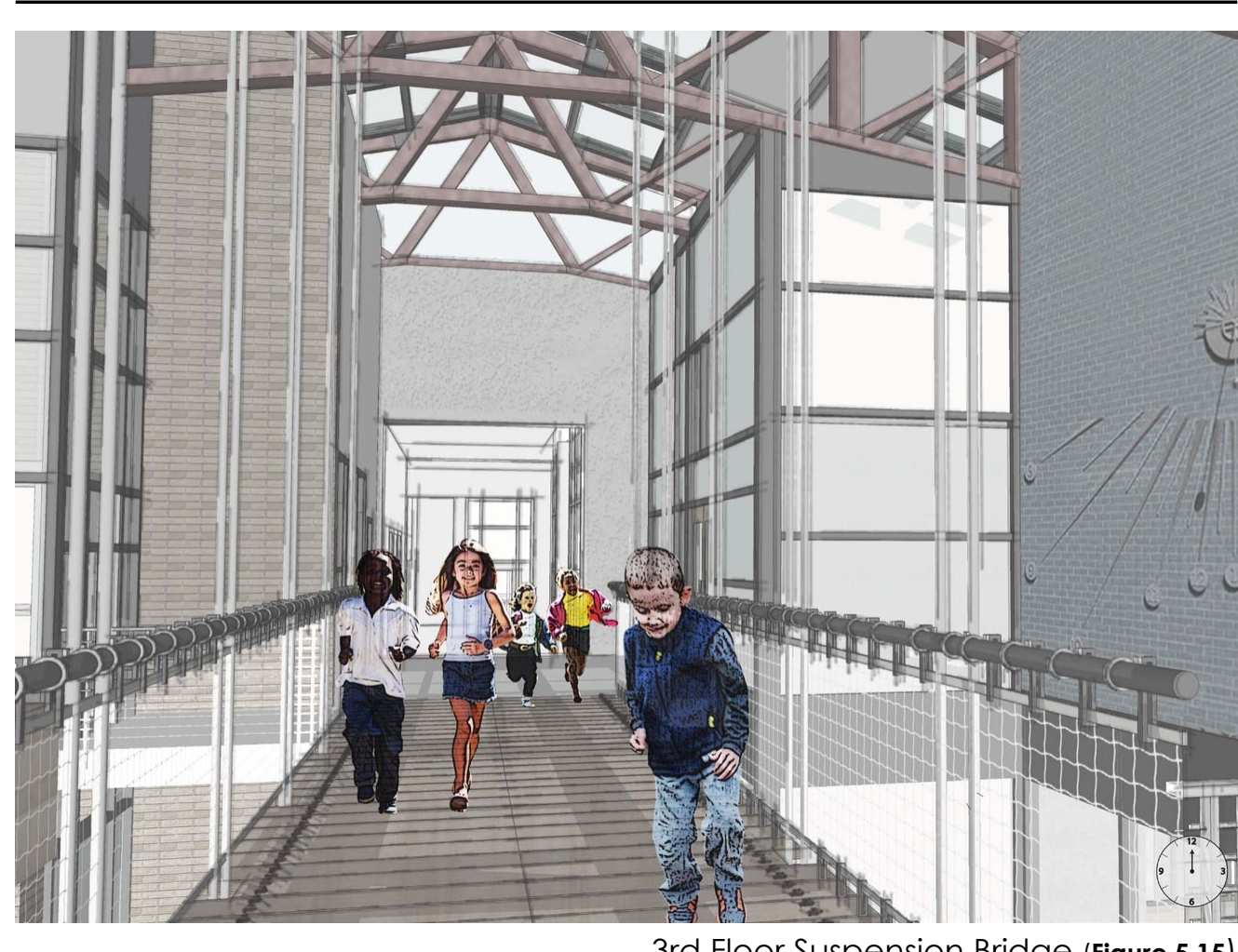

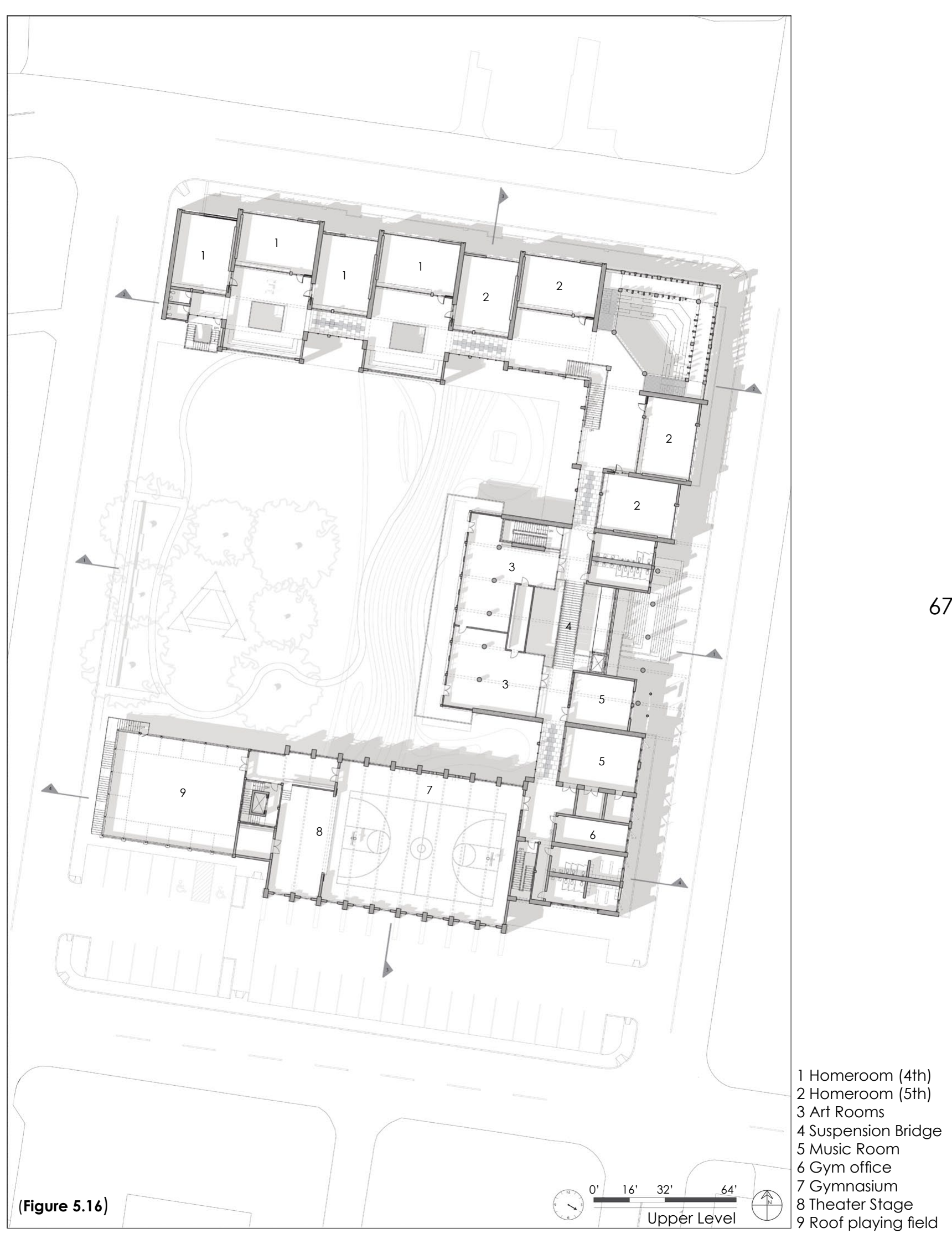




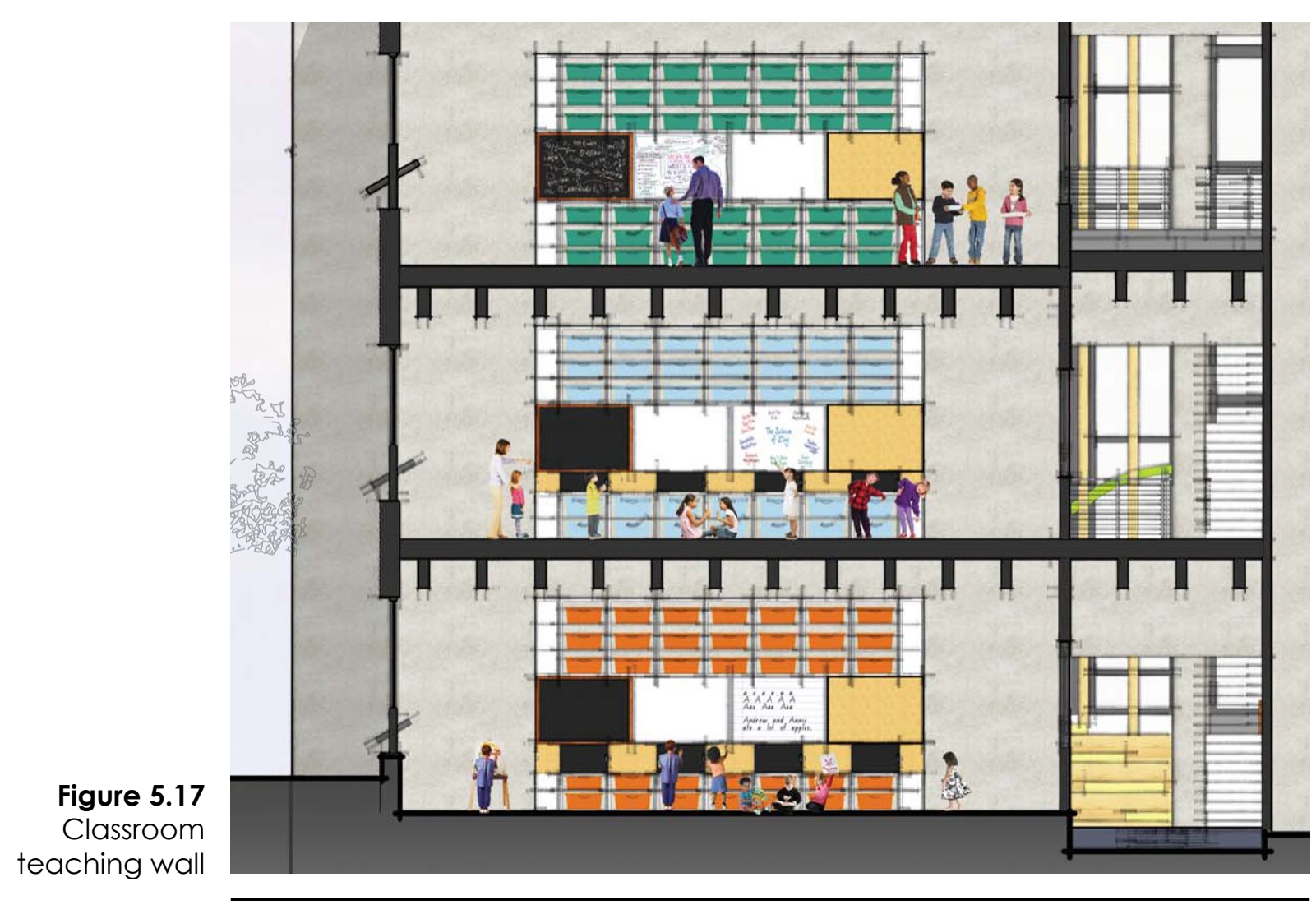

On sunny days, Liam's class takes a different route back to their homeroom. They descend down the staircase connecting the Health Center and gymnasium, across the courtyard following "The Loop" and through the side door at the northwest corner of the school (Figure 5.18). The end of the school day is often left for small group activity. Liam's teacher writes a question on the whiteboard and in small groups gathering around the teaching wall. The students problem-solve using various counting objects, chalkboards, and corkboards. As Liam graduates to the upper grades, the teaching wall adjusts to his growth and physical development (figure 5.17). By the end of the day, Liam has experienced all four types of Play: social, imaginative, object, and locomotor.
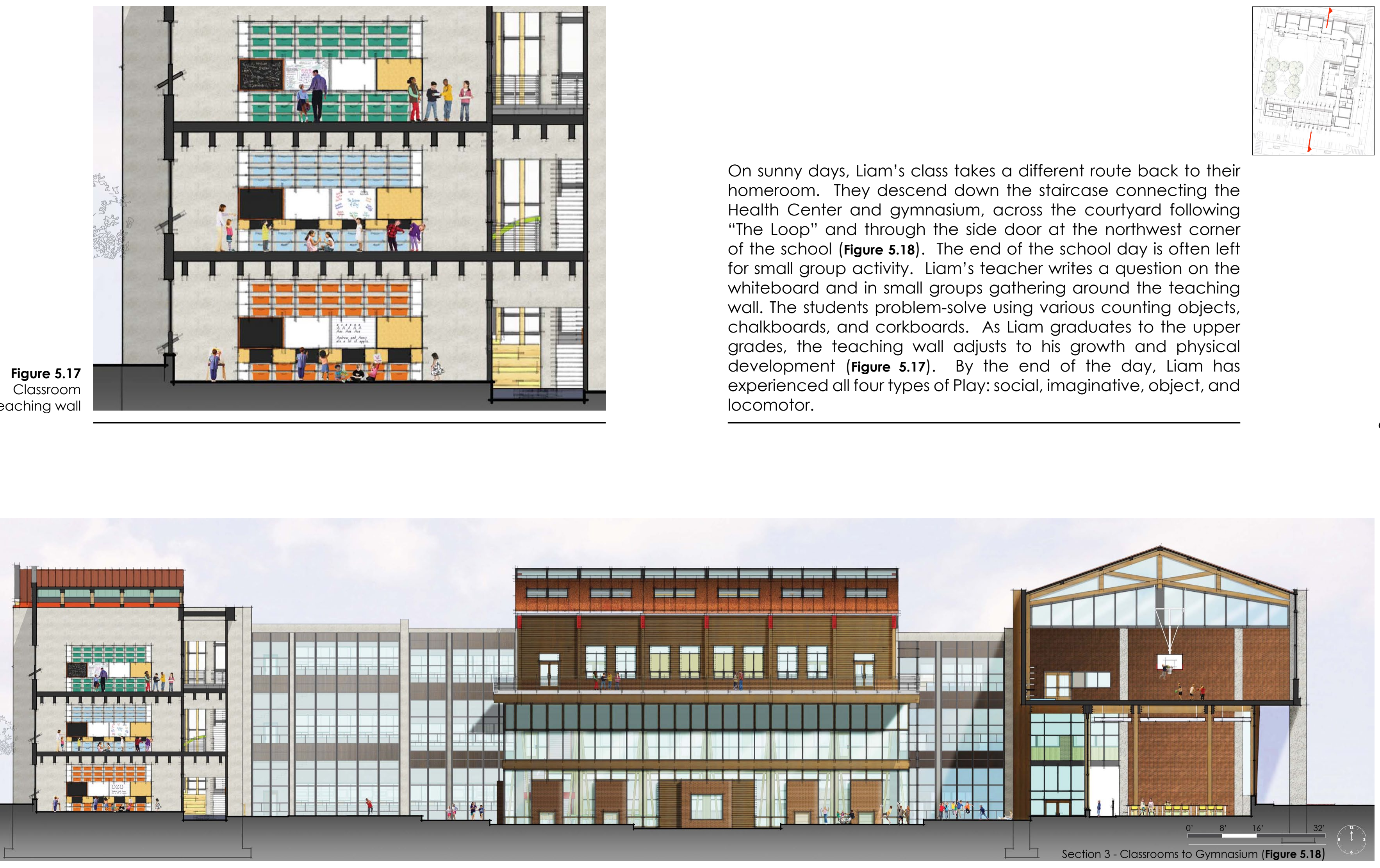

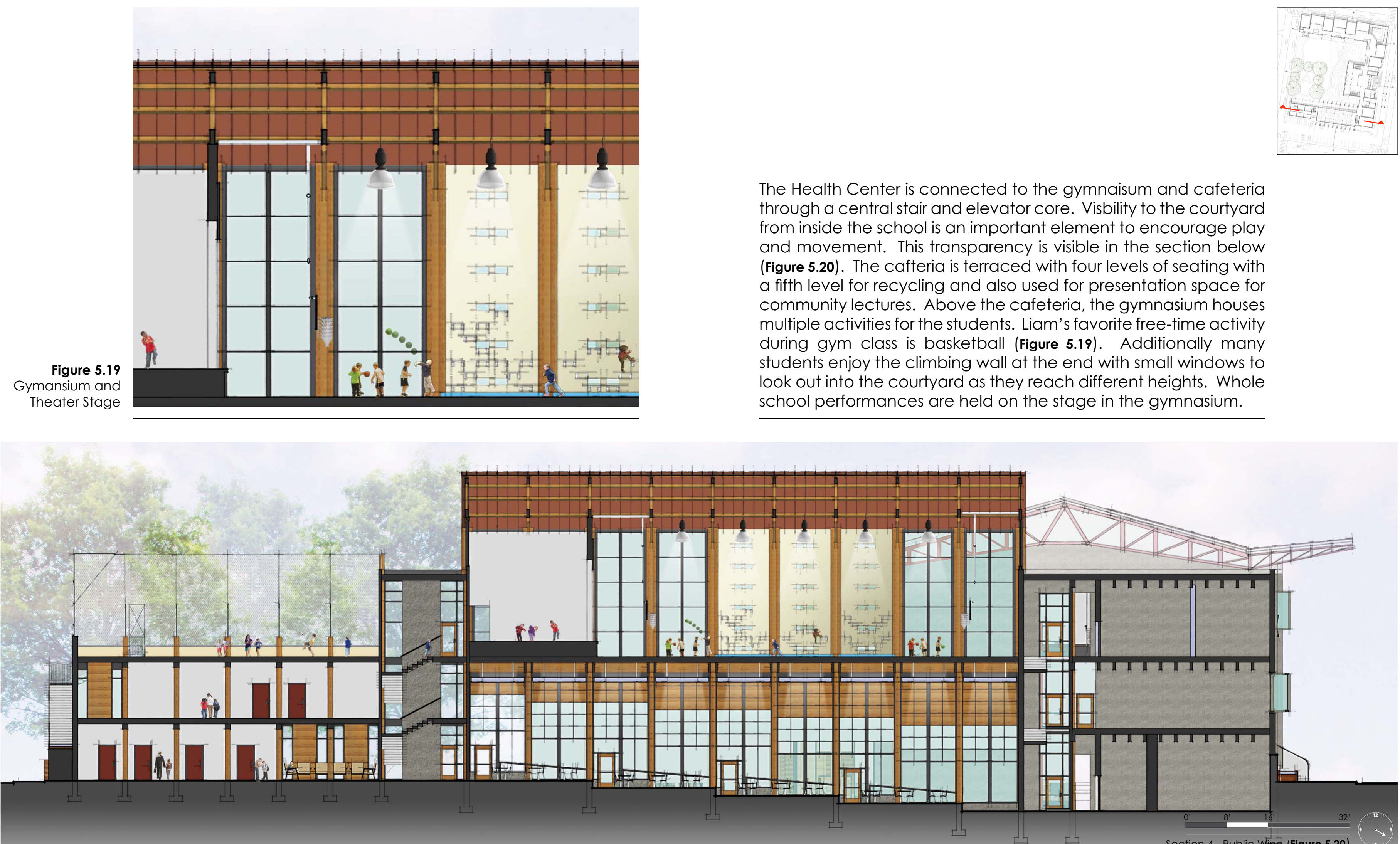

The Health Center is connected to the gymnaisum and cafeteria through a central stair and elevator core. Visbility to the courtyard from inside the school is an important element to encourage play and movement. This transparency is visible in the section below (Figure 5.20). The cafteria is terraced with four levels of seating with a fifth level for recycling and also used for presentation space for community lectures. Above the cafeteria, the gymnasium houses multiple activities for the students. Liam's favorite free-time activity during gym class is basketball (Figure 5.19). Additionally many students enjoy the climbing wall at the end with small windows to look out into the courtyard as they reach different heights. Whole school performances are held on the stage in the gymnasium. 

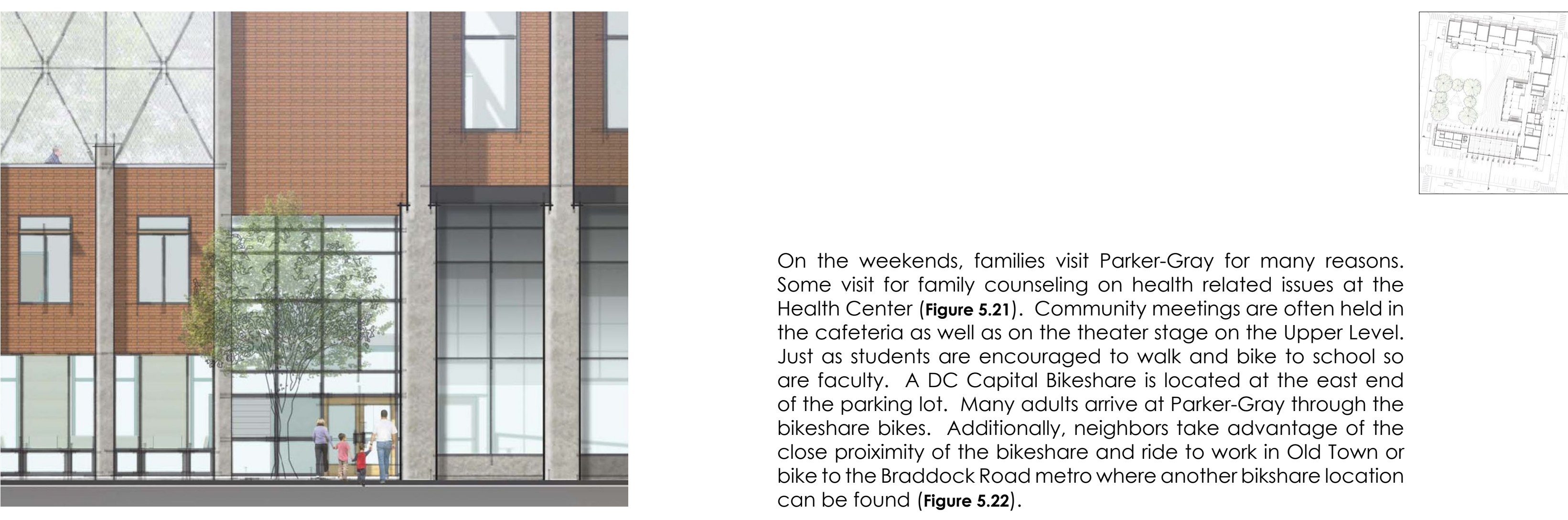

Figure 5.21 Public Health Center Entrance

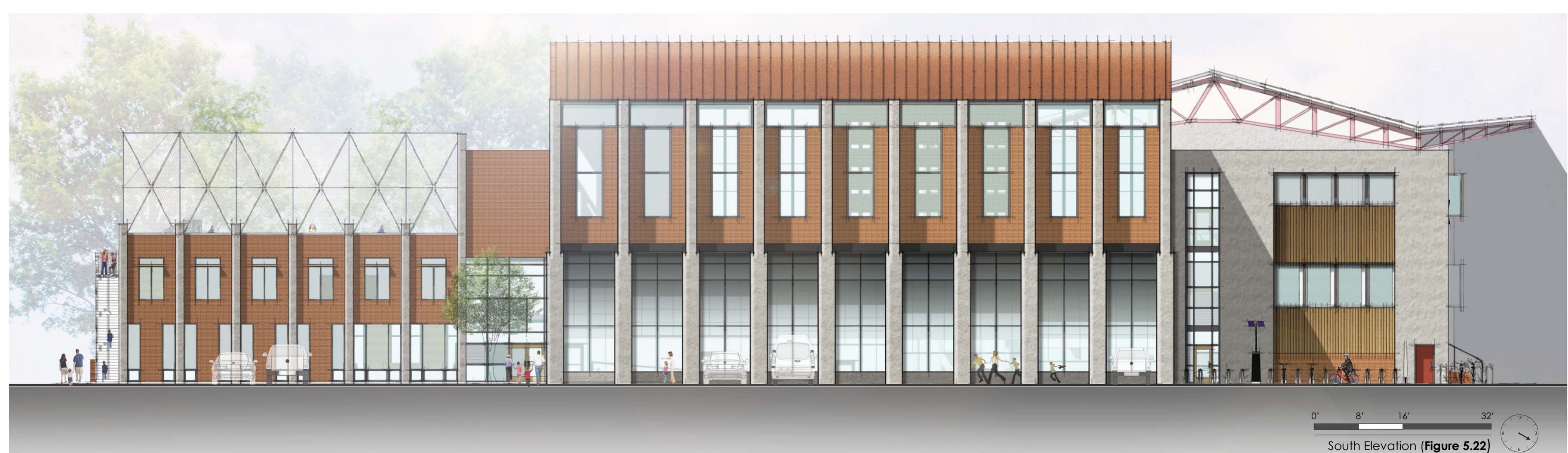

Some visit for family counseling on health related issues at the Health Center (Figure 5.21). Community meetings are often held in the cafeteria as well as on the theater stage on the Upper Level. Just as students are encouraged to walk and bike to school so are faculty. A DC Capital Bikeshare is located at the east end of the parking lot. Many adults arrive at Parker-Gray through the bikeshare bikes. Additionally, neighbors take advantage of the close proiximity of the bikeshare and ride to work in Old Town or bike to the Braddock Road metro where another bikshare location can be found (Figure 5.22). 


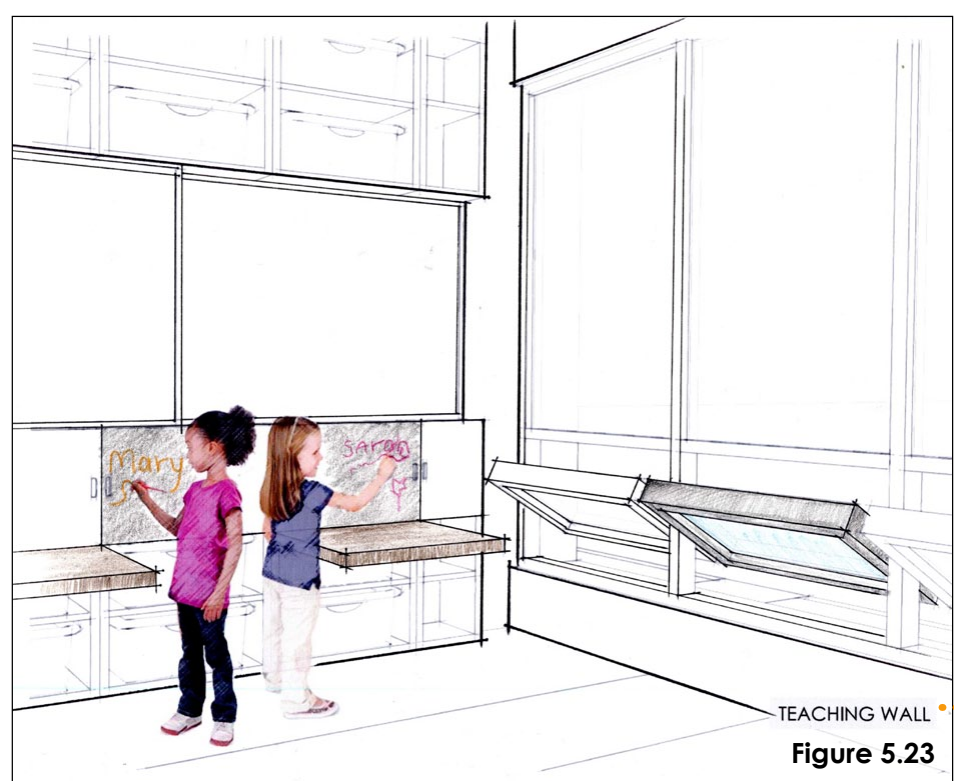

Kindergarten students work in small groups at the teaching wall. Chalkboards and corkboards are placed at the appropriate standing height for 5 and 6 year olds.

A four-foot high central pivot door is located on either side of the large garage door leading from "The Porch" to the courtyard. It is important that doors, windows, and shelving be scaled to the appropriate height of the student.

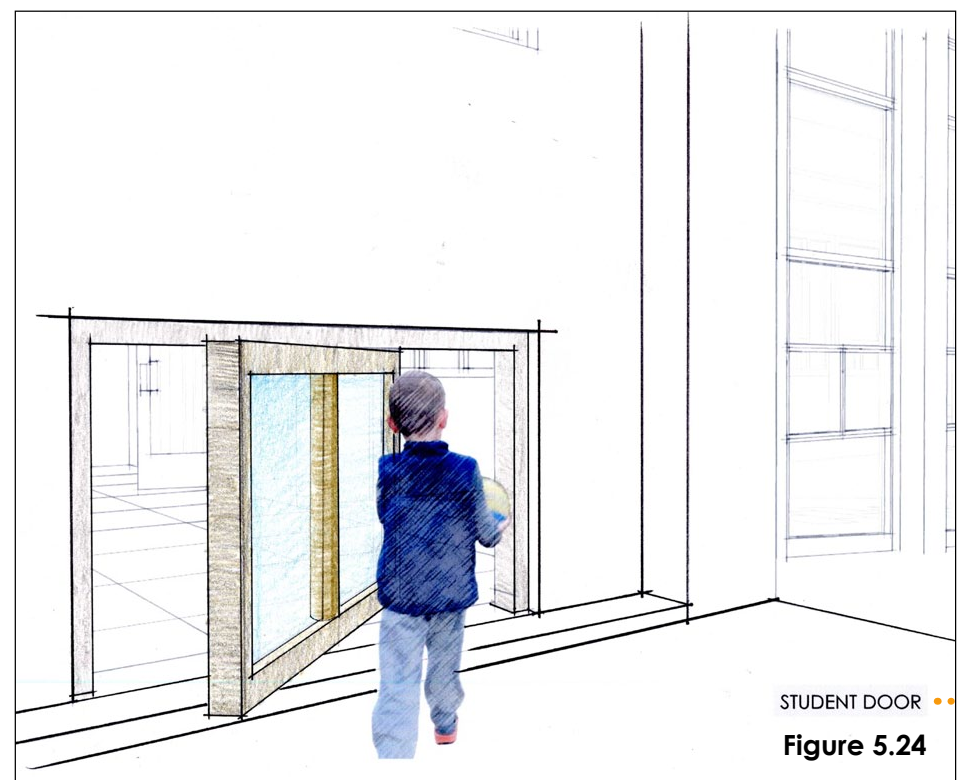

Material

change in the

hallway creates

hopscotch

patterns in

the floor for

children to

play on as they

move through

the school.

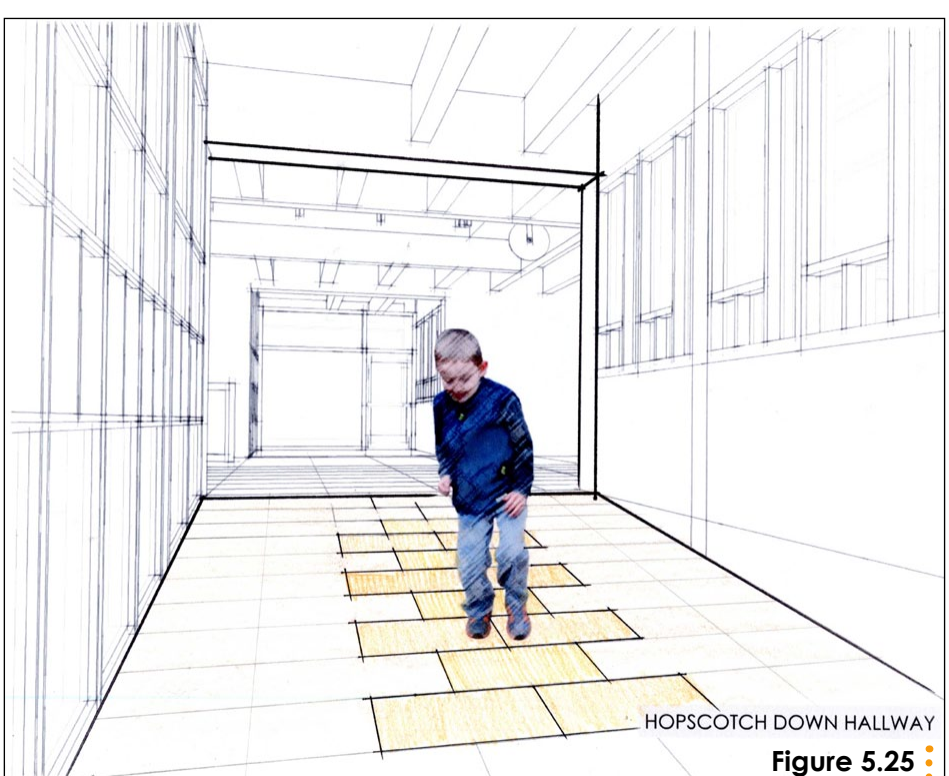

Figure 5.25 
A typical student desk and chair has been reimagined. The chair has transformed into a swing supported from the beams above with a folding desk arm for the worksurface and storage below. Students now have the ability to move while seated.

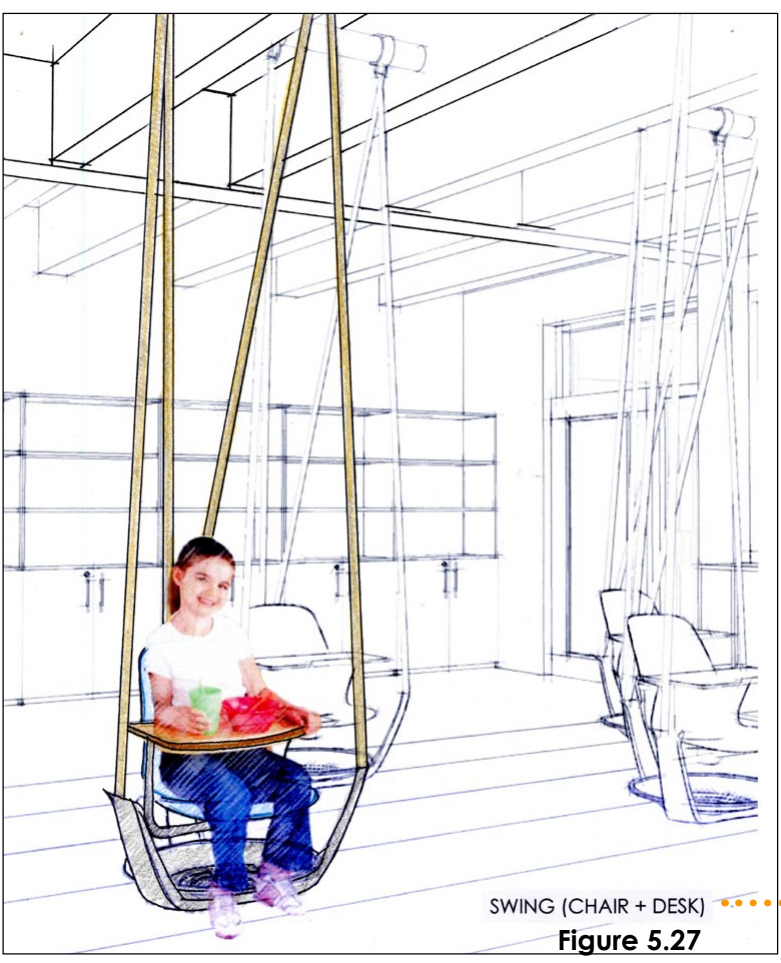

Students watch as classmates below opens the large garage door bringing the outdoors into the building through a series of pully systems. The classroom has extended beyond the four basic walls and into the courtyard.

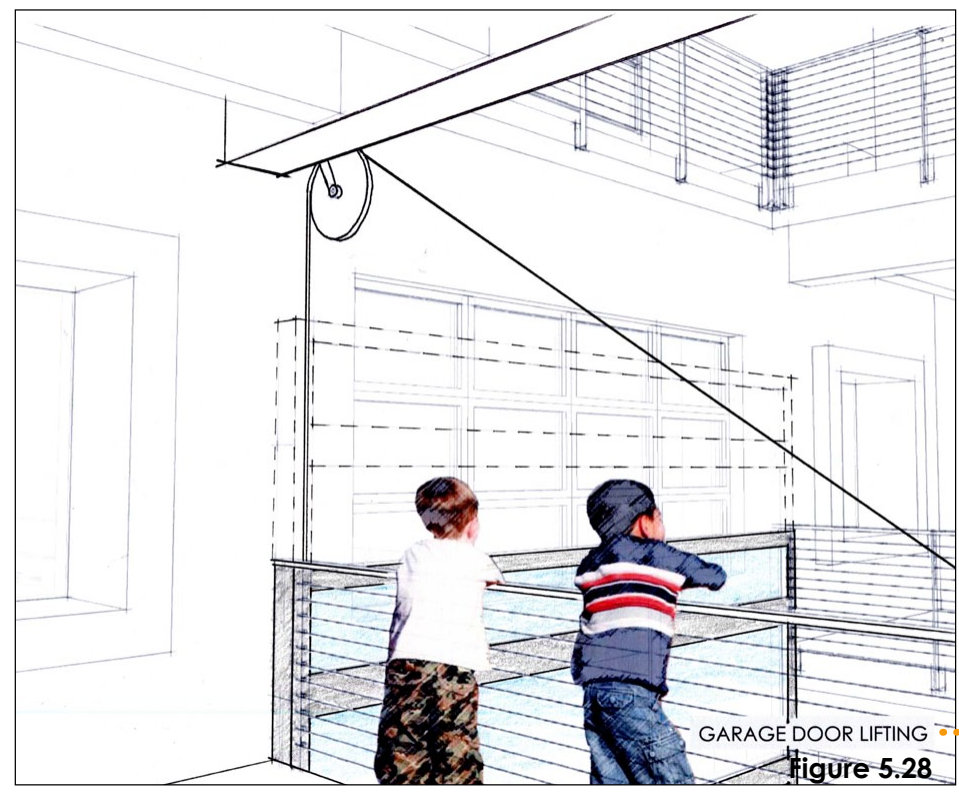

An exterior

window sits

within the

deep brick

wall facing into the courtyard

forming

reading

niches for

the students.

Similar reading

niches are

found in the

library.

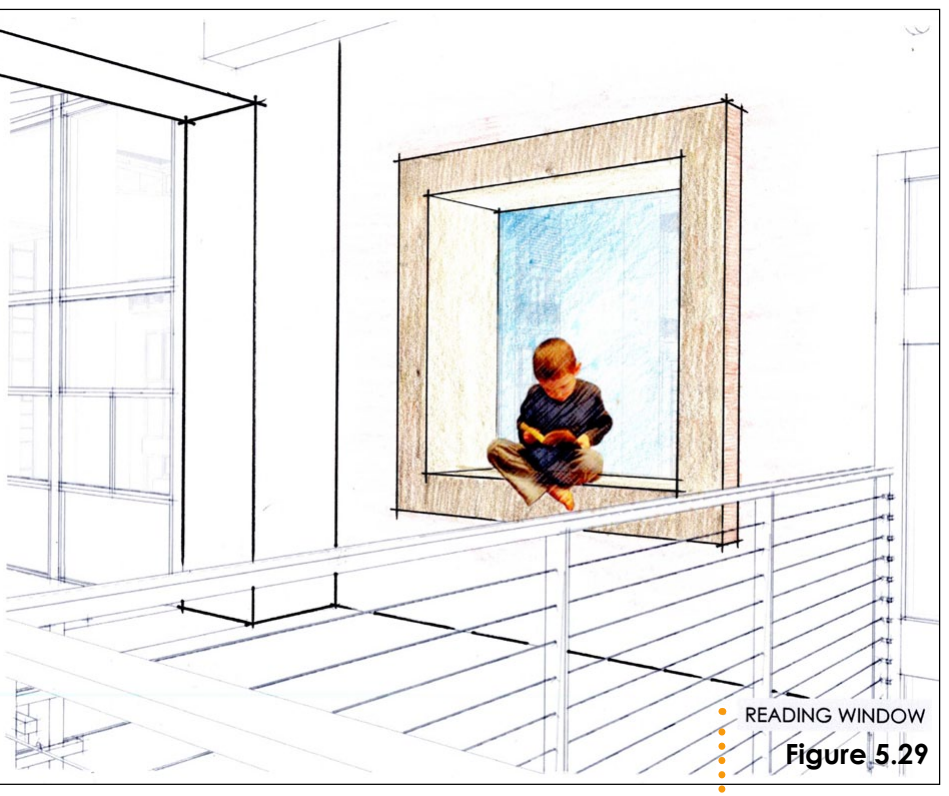

figure 5.29

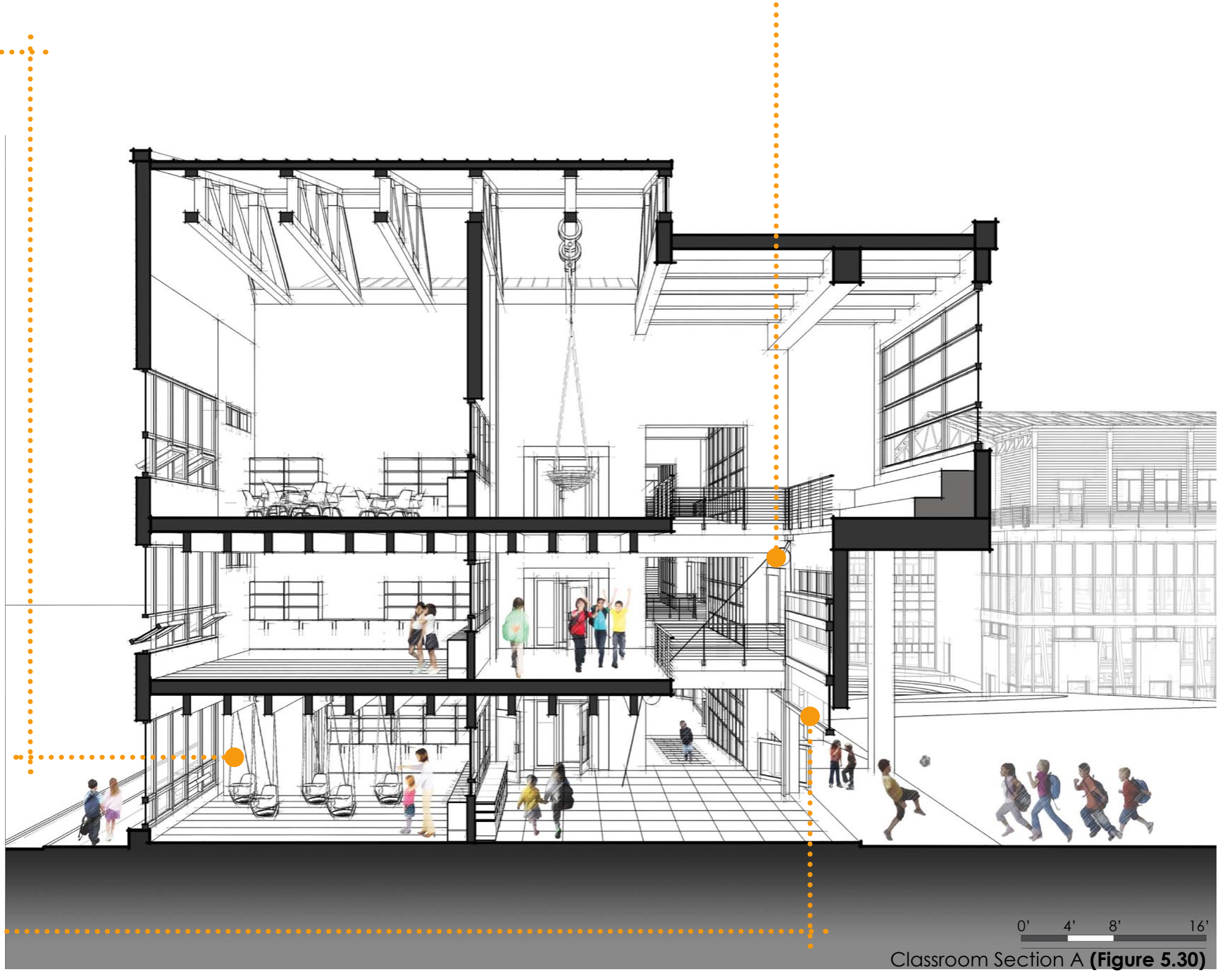




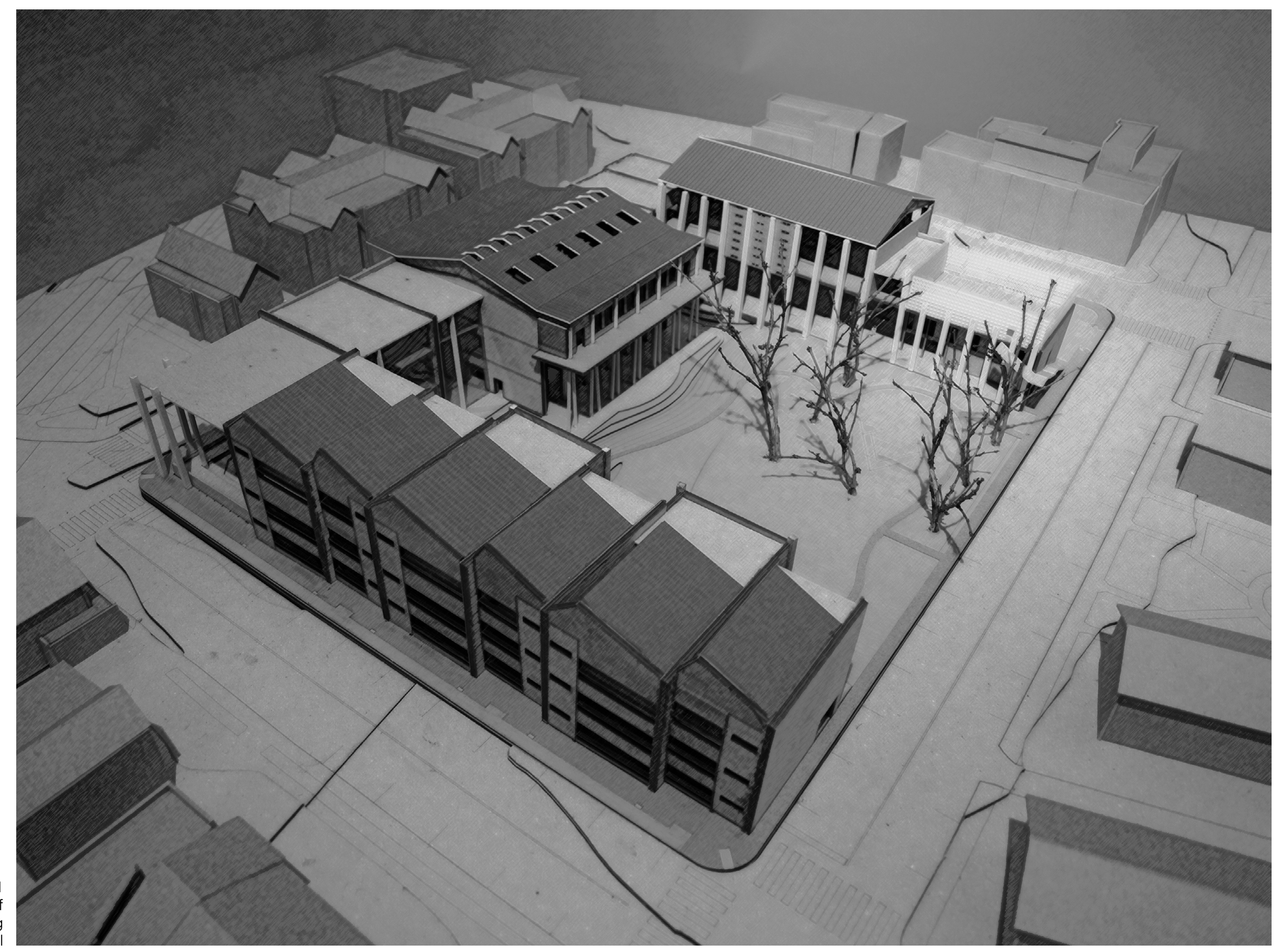


Case Study - Ashlawn Elementary

Arlington County, VA, USA

PreK - 5th grade

Children arrived to Ashlawn Elementary by CAR, BUS, BIKING AND WALKING Regardless of the student's typical mode of transportation to school, every student entered through the same main entrance of the school building. The students were then divided into three groups based on age and assembled in the multi-purpose room, gymnasium, or hallways of the relocatables. The kids were confINED WITHIN THE SCHOOL WALLS and were given little freedom to move and play before the morning bell. The outdoor fields and play spaces were left abandoned in the morning hours. By the time school started kids were already limited in their freedom to actively move by the walls of the school.

Each classroom is equipped with STUDENT DESKS AND CHAIRS, smartboards, teacher desks, storage, carpet areas, and group tables. Pre-K through 1st grade have restrooms, sinks, and individual cubbies inside the classrooms. 2nd grade through 5 th grade have lockers lining the hallways. When the students are given an assignment that allows them to work on their own or in groups and does not require the formal teacher let instruction, students dispersed throughout the classroom and migrate to CORNERS, NICHES, AND CARPETED AREAS where possible. This is true for all grade levels. The use of the standard desk and chair is not a preference for students when allowed the freedom to move throughout the classroom.

Ashlawn School is organized around the center courtyard with classrooms lining the four perimeter walls. The courtyard is UNDERUTILIZED FOR OUTDOOR SPACE and only acts as a sound barrier and daylight for the hallways. The hallways are quiet with low-ceilings and are only used for basic circulation needs to recess, speciality classes, and lunch. They are lined with quiet zone signs so as not to disturb other classes. The opportunity to engage students in ACTIVITY AND MOVEMENT within the hallways has been supressed by the noise restrictions.
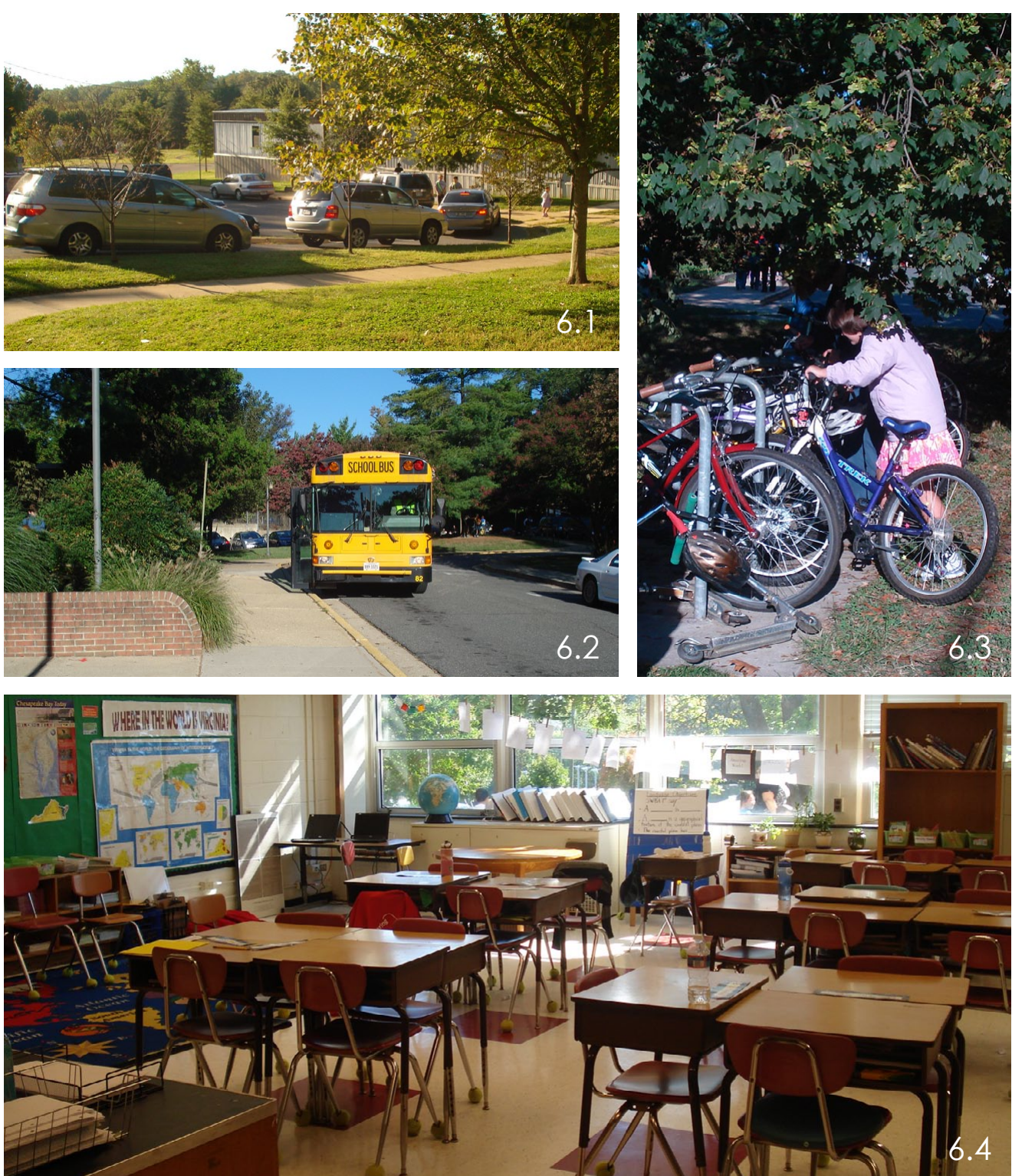

83
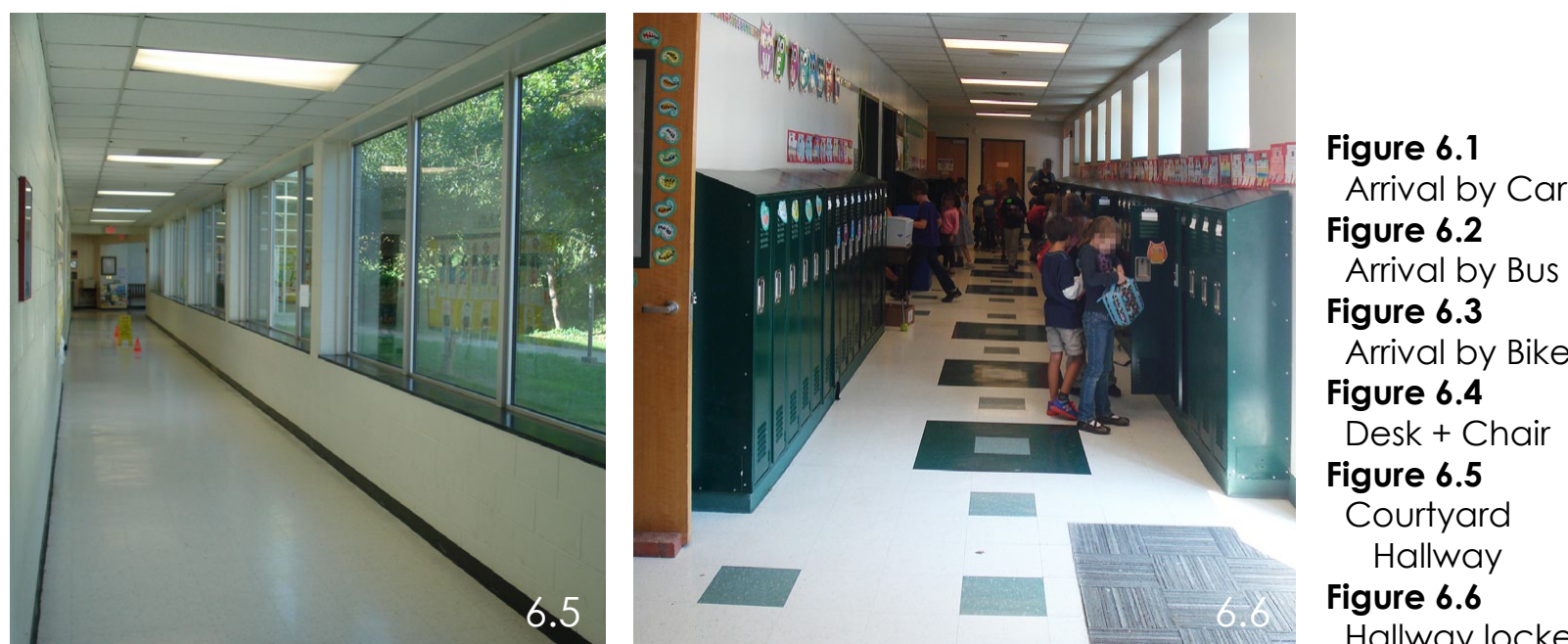

Figure 6.6 


\section{Case Study - Claremont Elementary \\ Arlington County, VA, USA \\ PreK - 5th grade}

On a typical sunny day, the morning drop-off is already chaotic enough between the cross traffic of cars, buses, and walkers. O

the $\mathbf{6 7 8}$ stUDENTS that attend Claremont Immersion Elementary daily, 504 RIDE THE BUS, 149 WALK, and the remaining 25 are supposed to be dropped off by car. However, during inclement weather, very few students walk resulting in over a hundred cars mixed with 10 12 buses all arriving within 15-20 minutes of each other. Needless to say, this results in major back-ups and delay of the morning school start. All students must enter through the same entry door regardless of their mode of transportation. While this is critical for security and safety of the students, the importance of COVERED SPACE MUST BE CONSIDERED AT THE ENTRY.

In the case of Claremont, the school has grown by almost 200 STUDENTS IN THE LAST TWO YEARS. Therefore, every extra indoor space has become occupied by students, teachers, and staff. Claremont has added an outdoor teaching space along the perimeter of their outdoor field spaces. This area provides teachers with an added opportunity for external and ENVIRONMENTAL LEARNING as well as FreEDOM to eXPLORE NATURE. While indoor break-out space is limited the outdoor classroom provides structure for initial teacher-led discussion followed by open areas for students to break-off in groups.

In most schools, hallways are viewed as basic circulation paths from point A to point B. The students are taught to stay quiet, no running, jumping, or climbing. The hallways have always been an opportunity to display announcements and student art work. . . but, COULD the HALLWAY BE MORE THAN THAT? At Claremont, the hallways still primarily serve as circulation paths. There are no niches or carved out spaces for one-on-one reading with the students. However, there is one element of the hallway that starts to ask more questions about student movemet and activity - THE RAMPs? Could the ramps within the hallways become an opportunity for students to engage in more activity than just quiet walking?
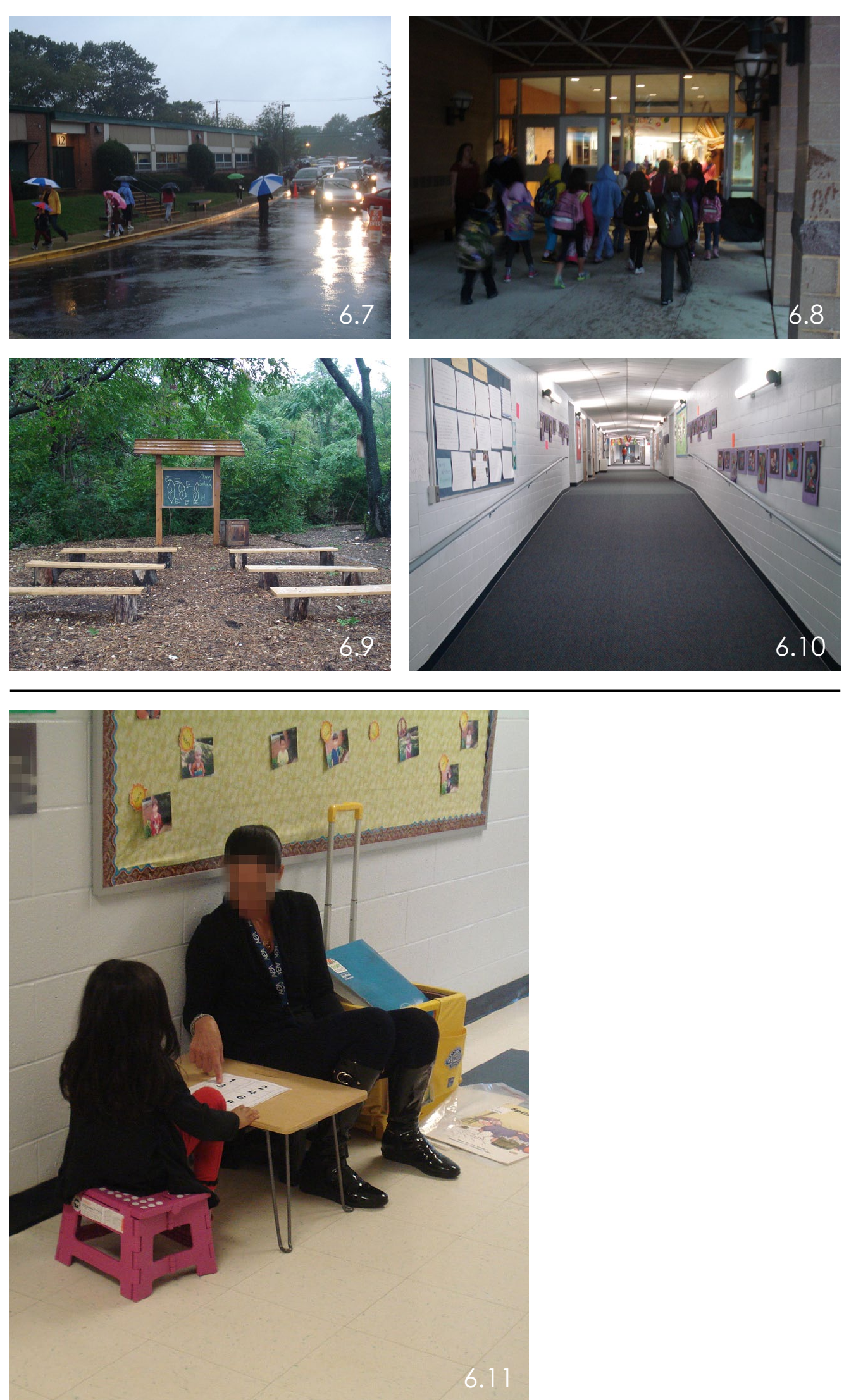

Figure 6.7 Bus + Car Arriva Figure 6.8 Main Entrance Figure 6.9 Outdoor Classroom Figure 6.10 Hallway Ramps Figure 6.11 Hallway 
Case Study-Lyles-Crouch Traditional Academy Alexandria, VA, USA $K$ - 5th grade

Lyles-Crouch encompasses a full city block of Old Town Alexandria's urban neighborhood. The entrance to the school sits at the southwest corner of the block. Through a series of ramps and stairs, the students enter school each day in an ACTIVE MODE, using and developing their motor skills immediately. Both the gymnasium and library anchor the main entrance alongside the front office. Children immediately run up the ramp to the right and down the hall to their classrooms. Engaging the students in active movement at the beginning of their day INCREASES THEIR PHYSICAL AND COGNITIVE DEVELOPMENT.

A public school yard serves as a playground for the school during the day and expands to a neighborhood playground in the evenings and weekends. The school yard should provide a wide RANGE OF PLAY INTERACTIONS FROM ORGANIZED TO INFORMAL. While Lyles-CrOUCh provides a variety of open grass, swings, slides, and other basic playground structures, the outdoor play space fails to engage the child in a way in which they are provided opportunities to explore and use their imagination to play. The flat open space lacks grade changes, niches, corners, tunnels, etc. which invite children †O DEVELOP THEIR FUNDAMENTAL MOTOR SKILLS IN A CREATIVE WAYS.

Schools have the opportunity to teach children healthy eating habits. Visible to the community and school, Lyles-Crouch has four raised garden beds. Through extra-curricular programs, students are taught about the BENEFITS OF FRESH FOOD. They learn to cook from scratch and use vegetables planted in the garden beds. No only is Lyles-Crouch teaching their students to eat healthy, they also have several Programs THAT ENCOURAGE STUDENTS TO WALK AND BIKE TO school such as "Planet Crusaders". While all of these programs are excellent and a beginning to encourage students to lead active healthy lifestyle, they need to be embedded within the core curriculum of the school and not only offered as extra-curricular activities.

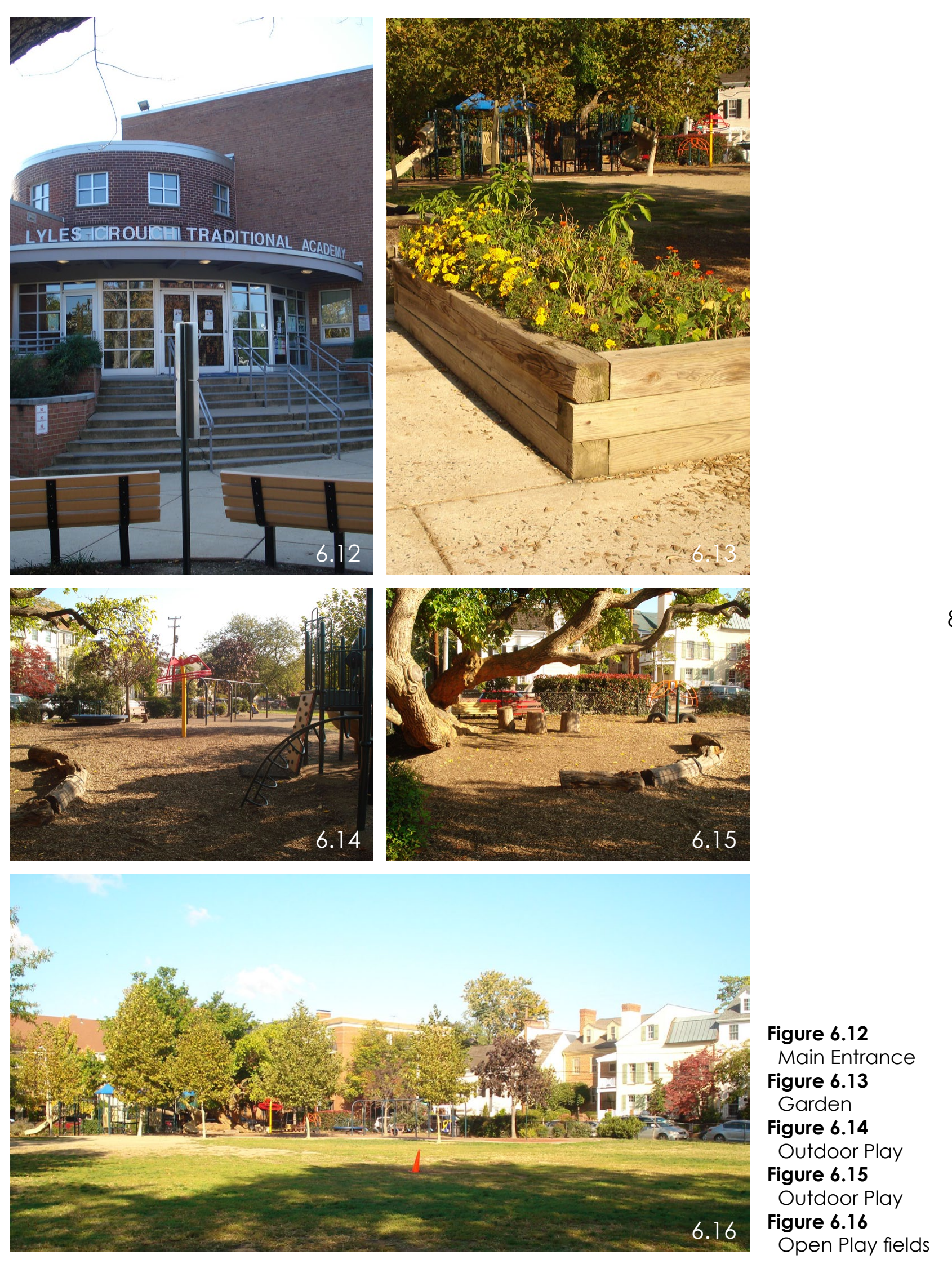




\section{Case Study - John Adams Elementary Alexandria, VA, USA \\ PreK - 5th grade}

The entry of the school must serve multiple purposes. First, it creates an identity for the school. A small, dark front entrance sets the tone for the school's outward appearance to both students and visitors. The entrance at John Adams is set back from the street edge with a large, low canopy across three sets of double doors. Very little glazing allows for MORNING AND AFTERNOON SUN TO FILTER INTO the FRONT ENTRANCE. Although security is always an important factor for the front entrance, John Adams' entrance lacks any sense of warmth or inviting nature for learning.

The majority of the stairwells within John Adams are typical CMU block construction with neutral color tile and no windows. A child spends several parts of the day traveling to and from speciality classes, lunch, recess, etc. During this time the stairwells are used heavily. Creating more vibrant and inviting transition spaces can improve a child's attitude. Filling the stair walls with graphics and signage creates an additional teaching tool that can help explain the BENEFITS OF STAIRS AND WALKING IN LEADING AN ACTIVE, HEALTHY LIFESTYLE. Daylight should also flood the stairs creating a continuity between the indoor and outdoor environment.

The school grounds at John Adams' offers a wide variety of play and social interactions. Several pieces of playground equipment complete with swings, slides, tunnels, and climbing walls are tucked into the northeast corner of the site. Basketball courts, four-square surfaces, soccer fields, and kickball surfaces are also included. Visible in the pictures to the right, three different outdoor classrooms exist providing additional teaching spaces beyond the walls of the indoor classroom. By providing a variety of playground structures, play surfaces, and outdoor rooms, children have the opportunity to engage in the four types of play: LOCOMOTOR, OВJECT, SOCIAL, AND IMAGINATIVE.
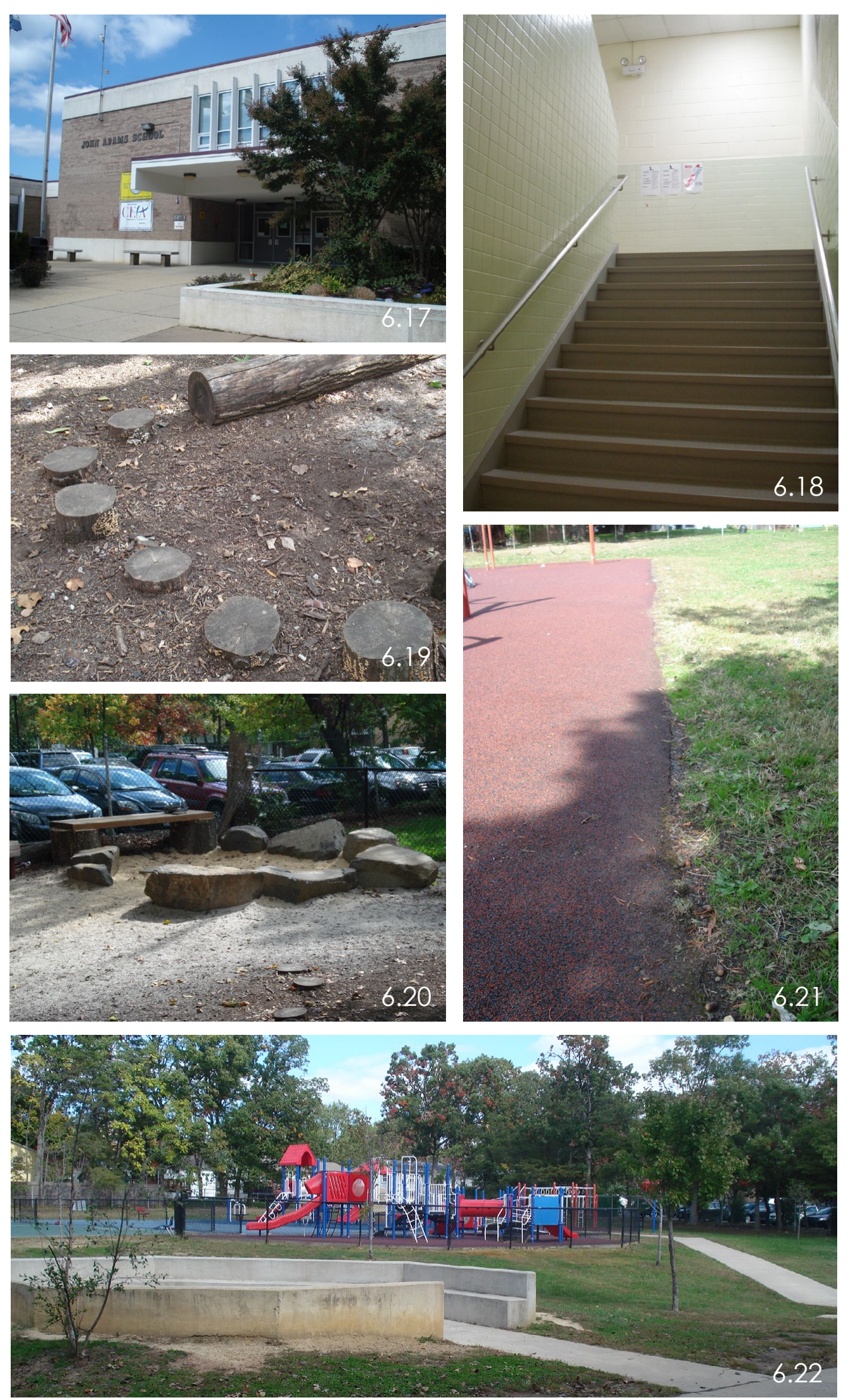

Figure 6.17 Main Entrance Fure 6.18 Egress Stair igure 6.19 Natural landscape Figure 6.20 Outdoor classroom Material change Figure 6.22 
Case Study - Play Work Build (exhibit) National Building Museum, Washington, DC Imagination Playground by Rockwell Group

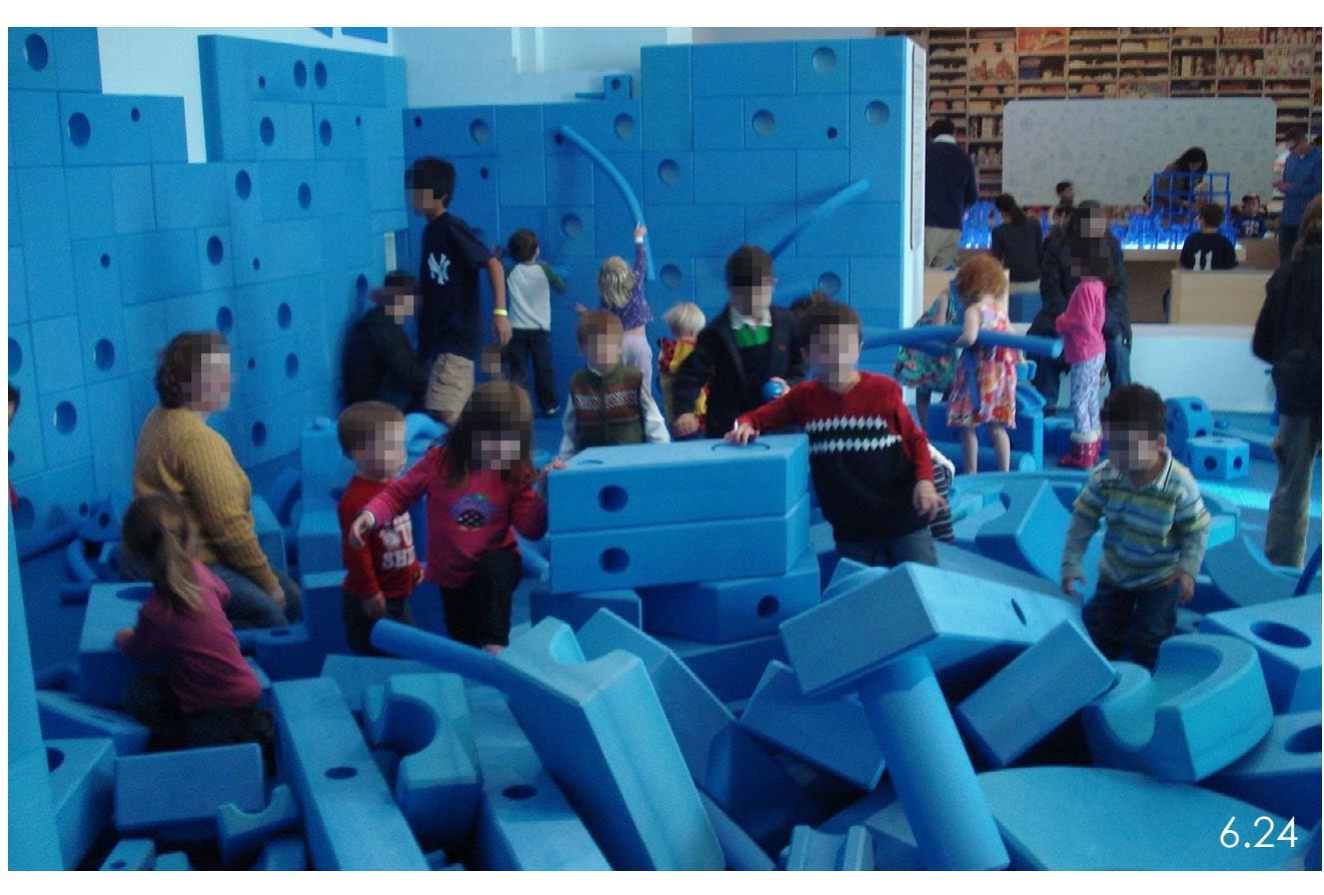

90 ACTIVITY, PHYSICAL MOVEMENT, AND NO RESEMBLANCE TOA

TYPICAL PLAYGROUND

ARE THE THREE MAJOR

THEMES OF THIS

$D C$

(WWW.NBM.ORG)
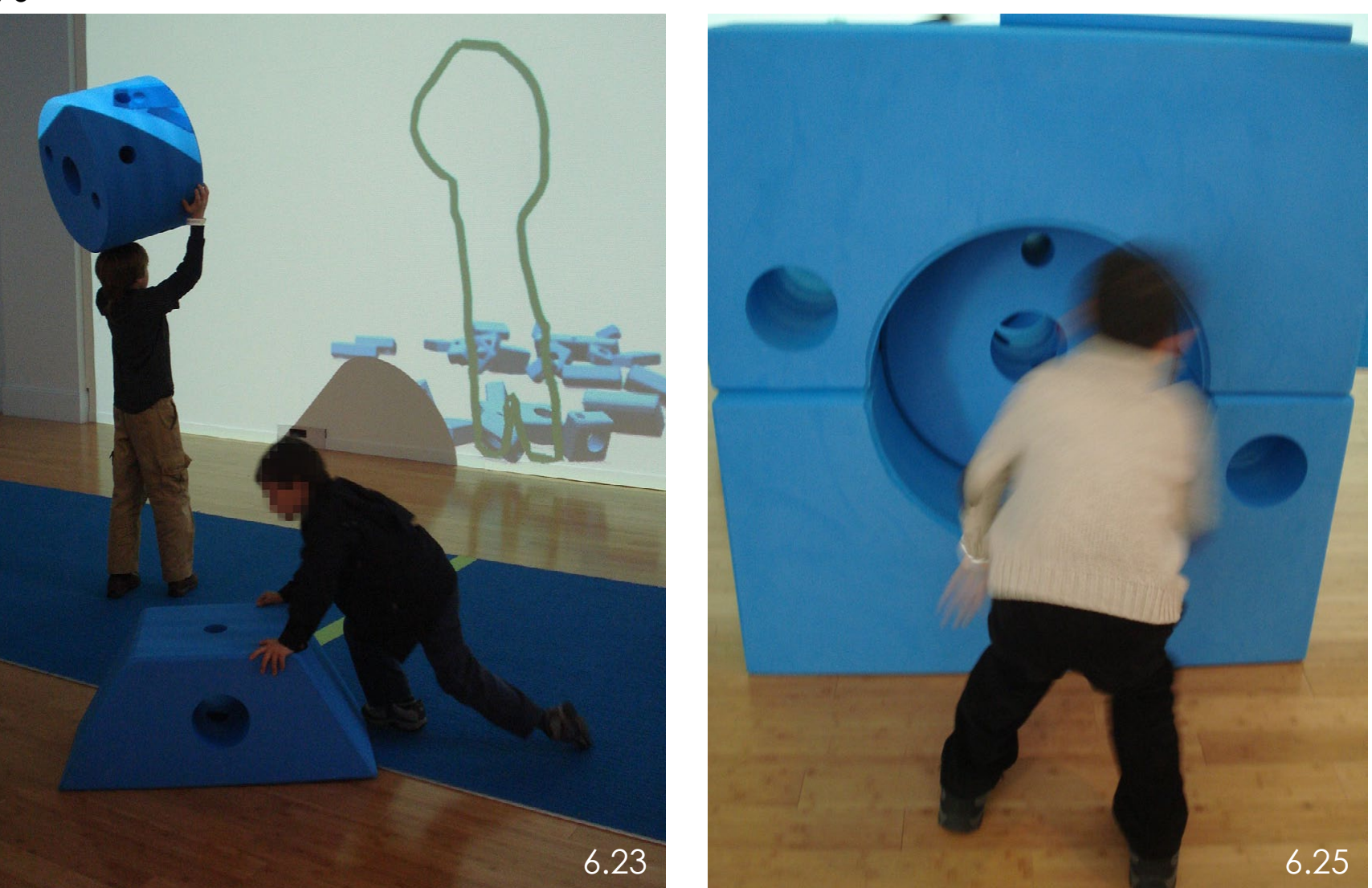
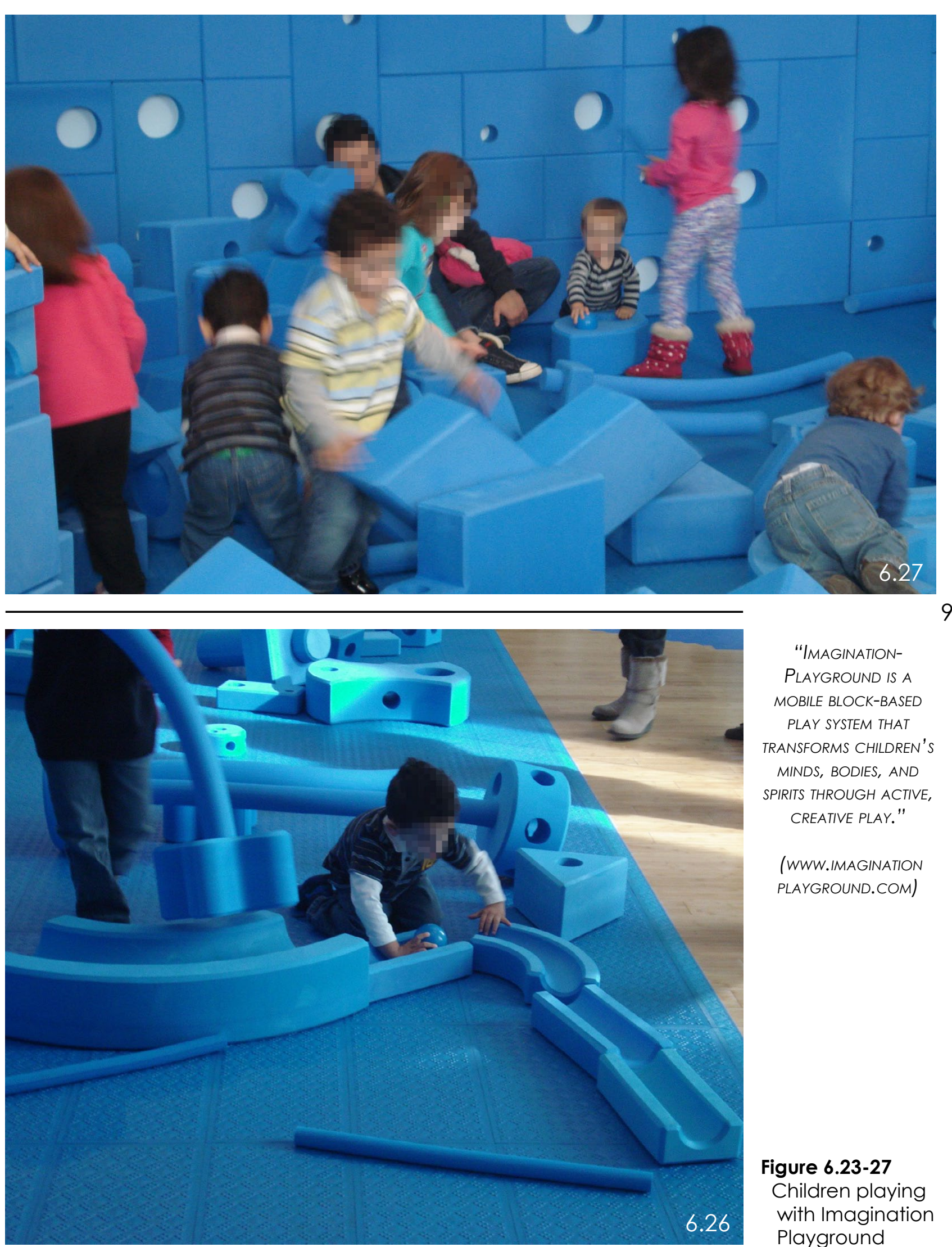

"IMAGINATIONPLAYGROUND IS A

MOBILE BLOCK-BASED

PLAY SYSTEM THAT

TRANSFORMS CHILDREN'S

MINDS, BODIES, AND

SPIRIS THROUGH ACTIVE,

CREATIVE PLAY."

(WWW.IMAGINATION PLAYGROUND.COM)

Figure 6.23-27 Children playing with Imagination 
Case Study - Climbing Wall

Children's Museum of Pittsburgh, Pittsburgh, PA

Designed by Koning Eizenberg (Design Architect)

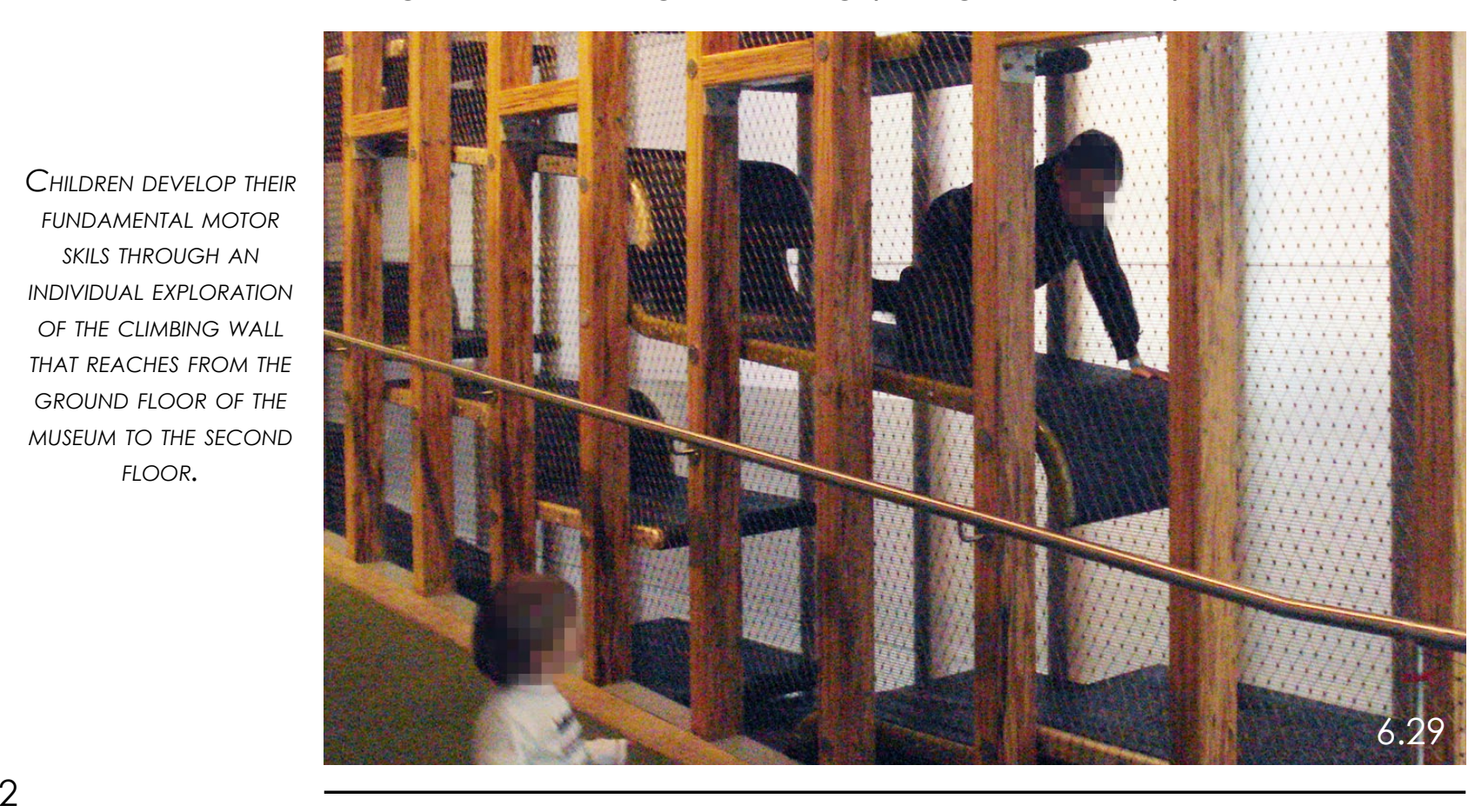

92

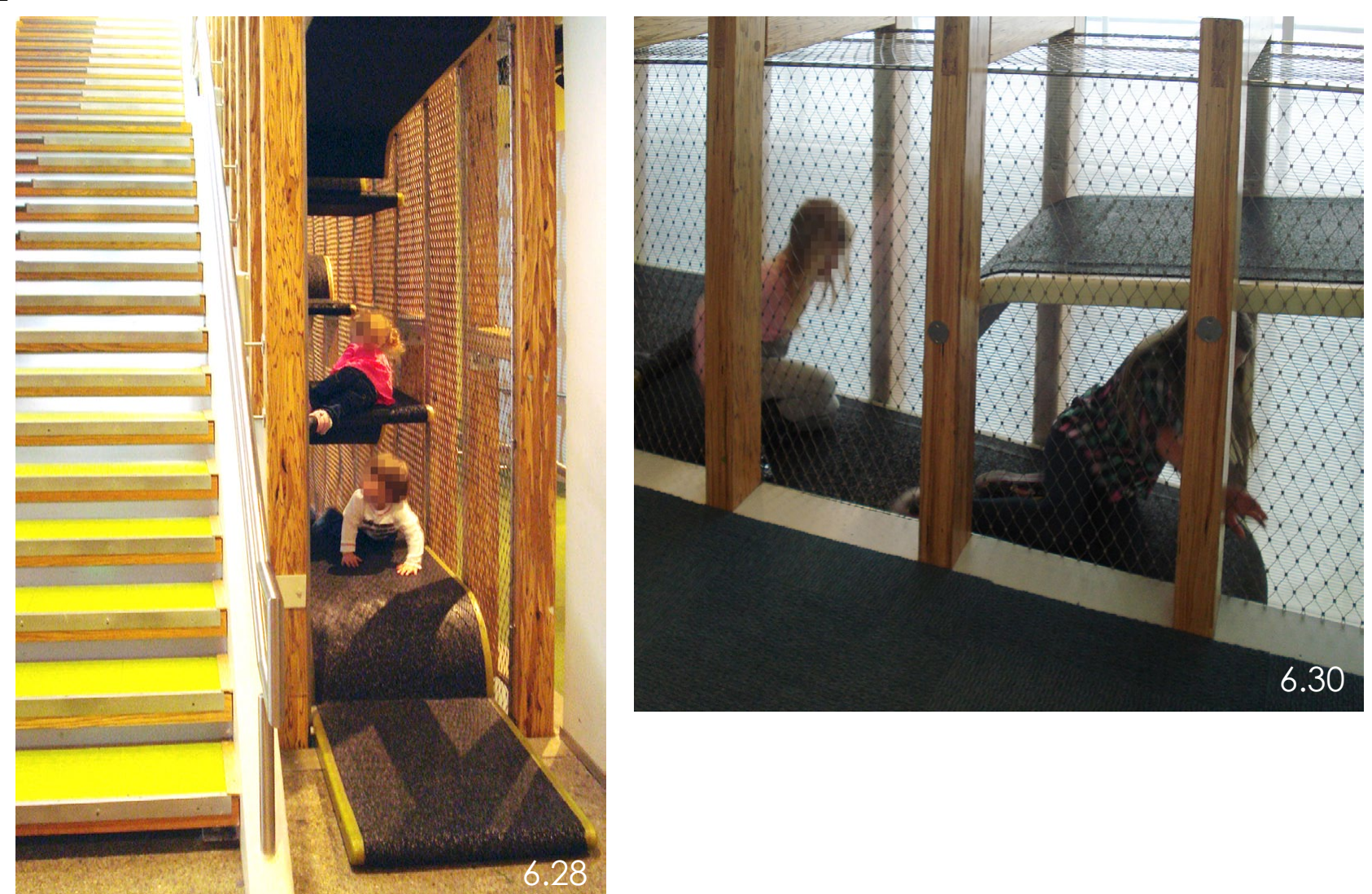

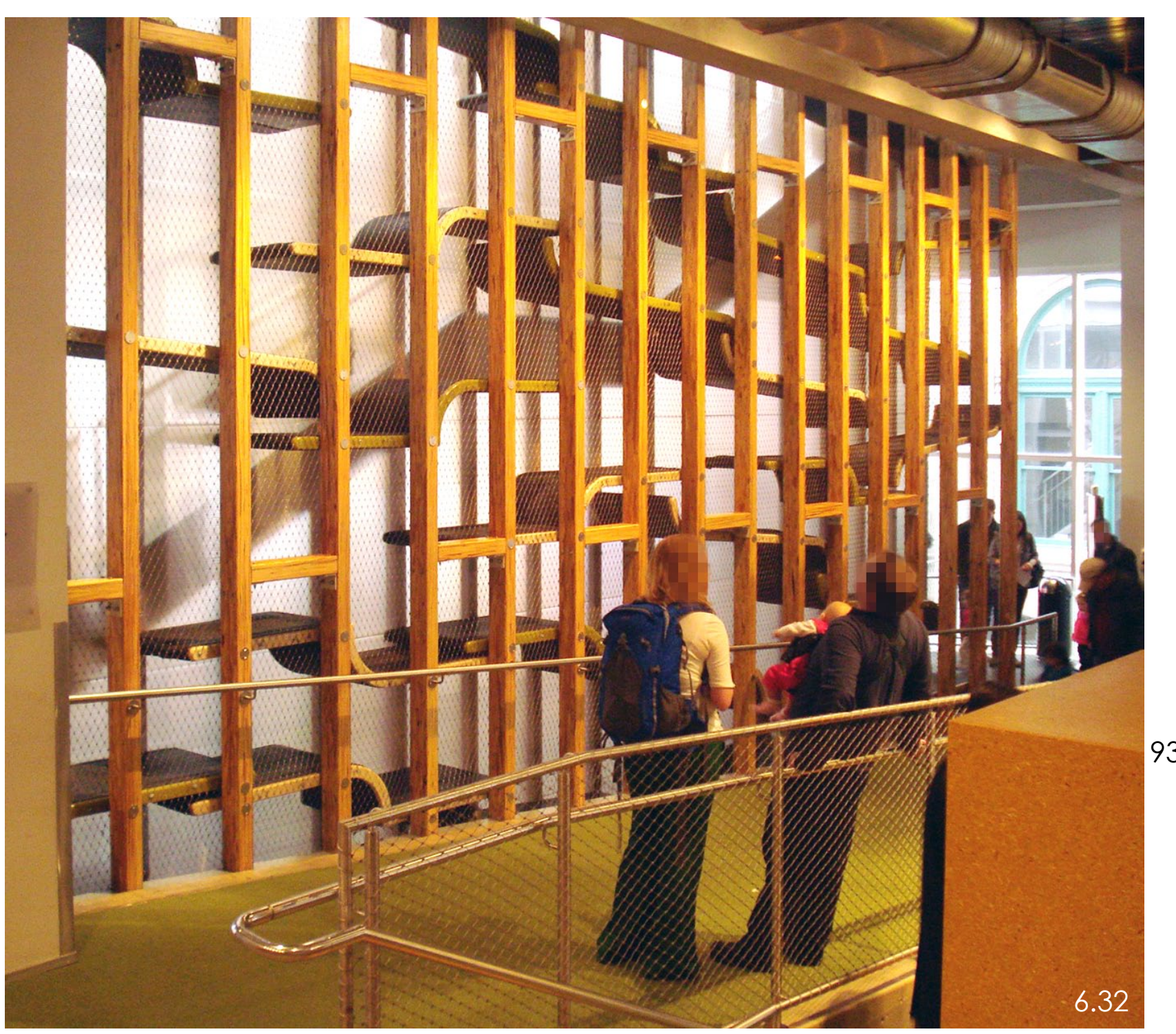

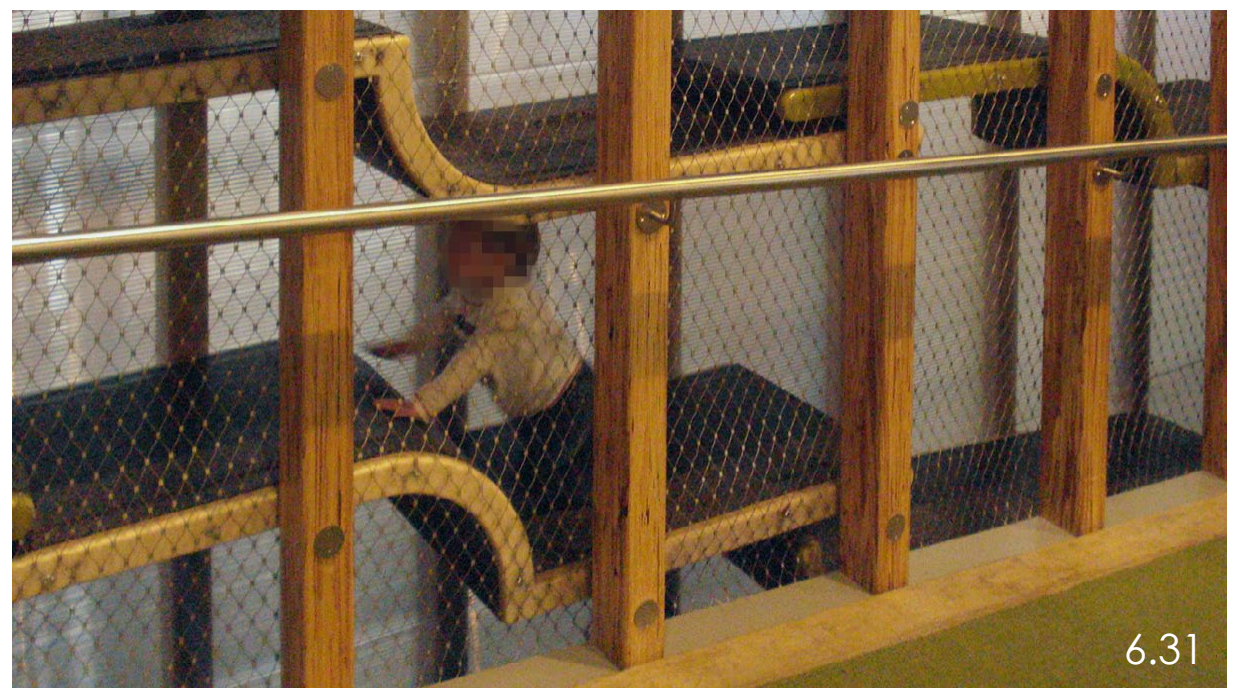

Figure 6.28-32 Children climbing through wall 
Case Study - Wall-holla

Netherlands

Desgined by Carve

"The Wall-holla COMBINES MANY PLAY POSSIBLTIES FOR DIFFERENT AGE GROUPS ON A MINIMUM OF" SQUARE METERS." (WWW.WALL-HOLLA. СОM)

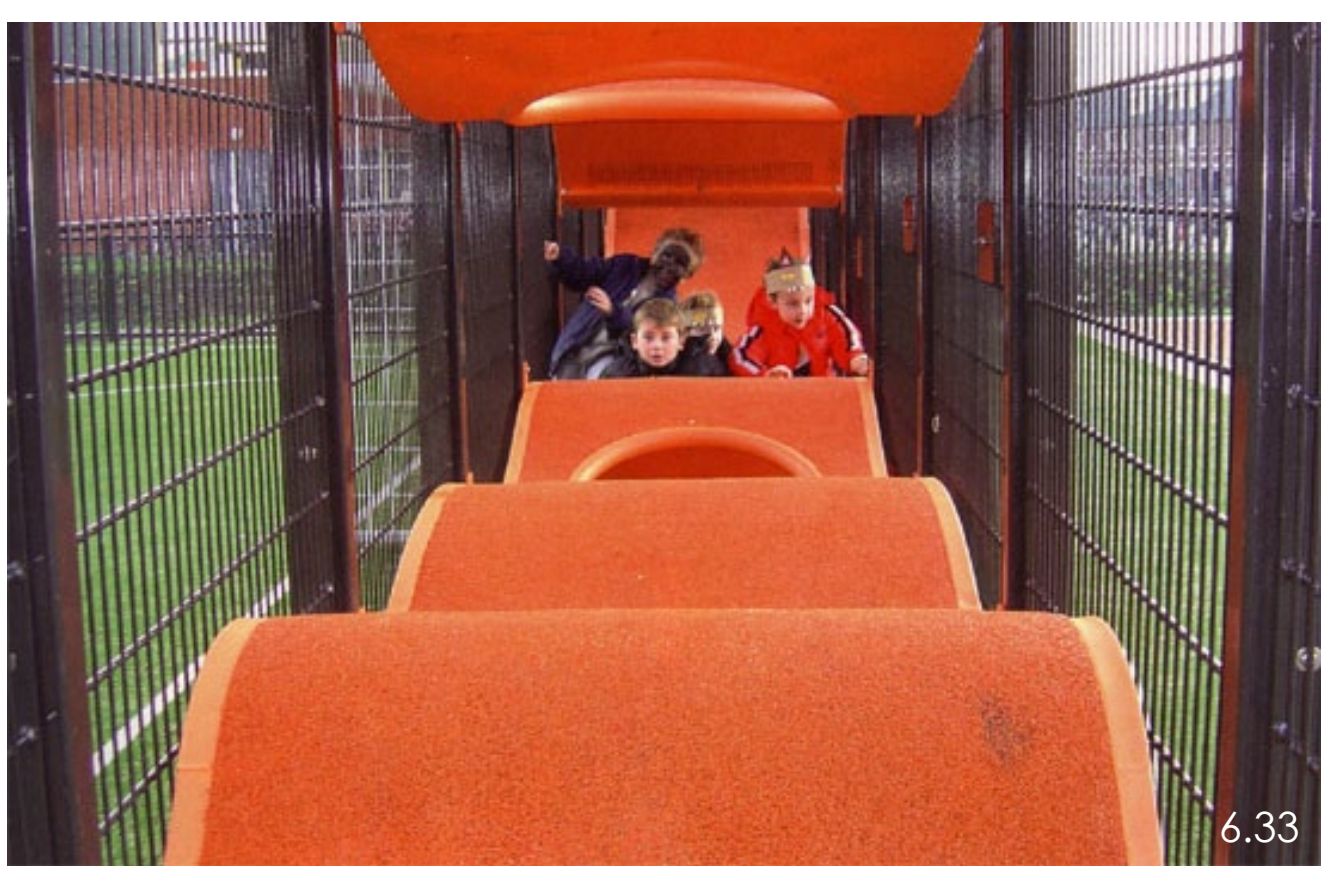

94

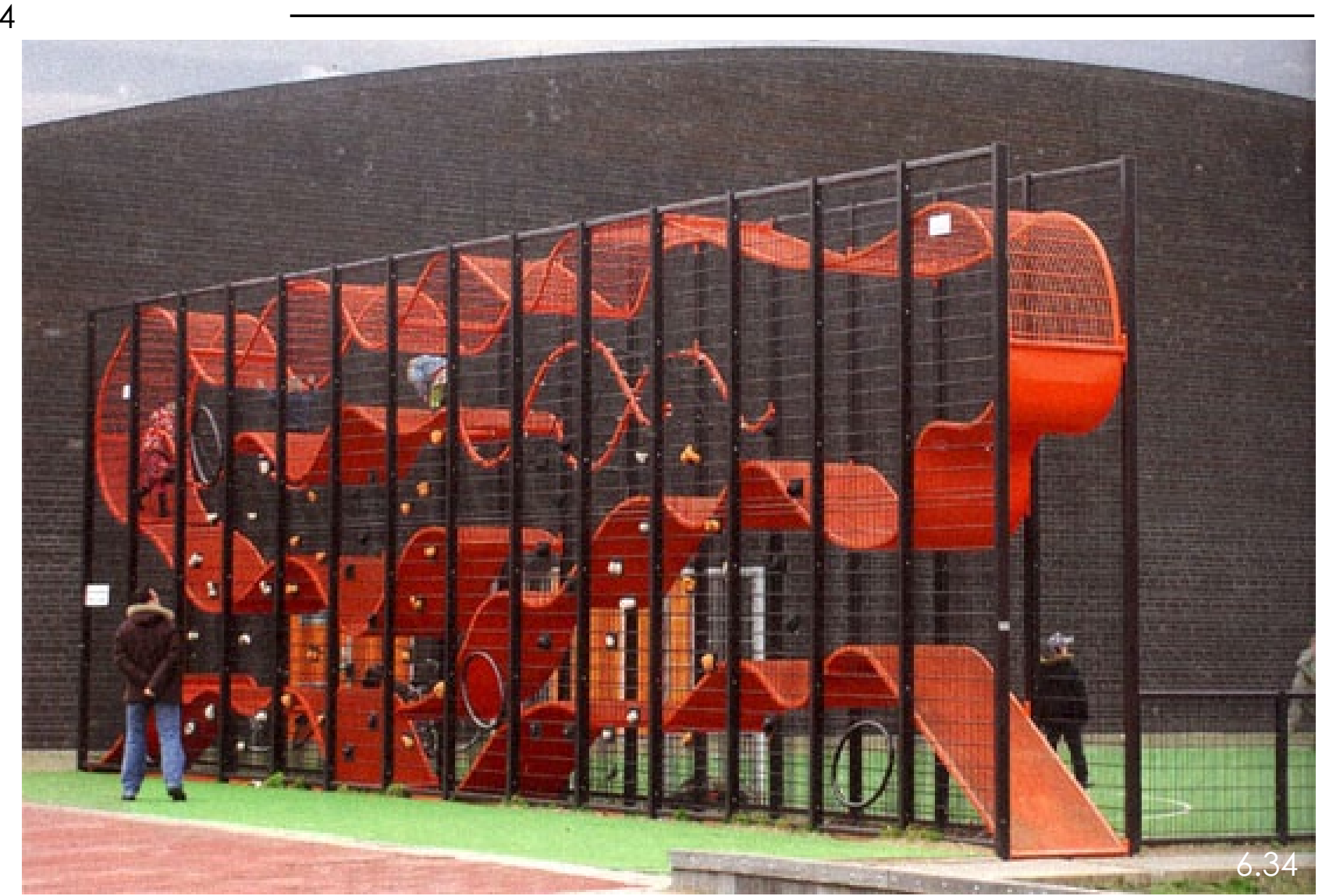

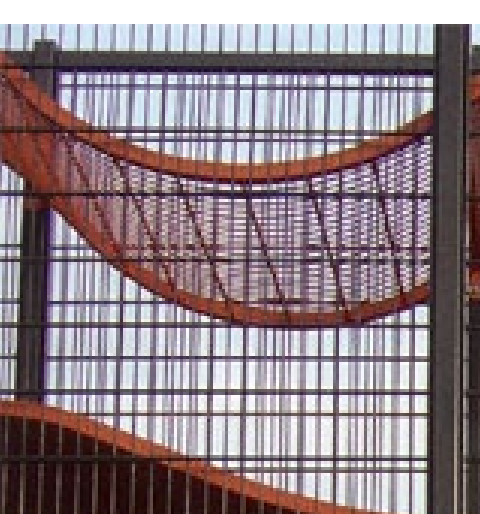
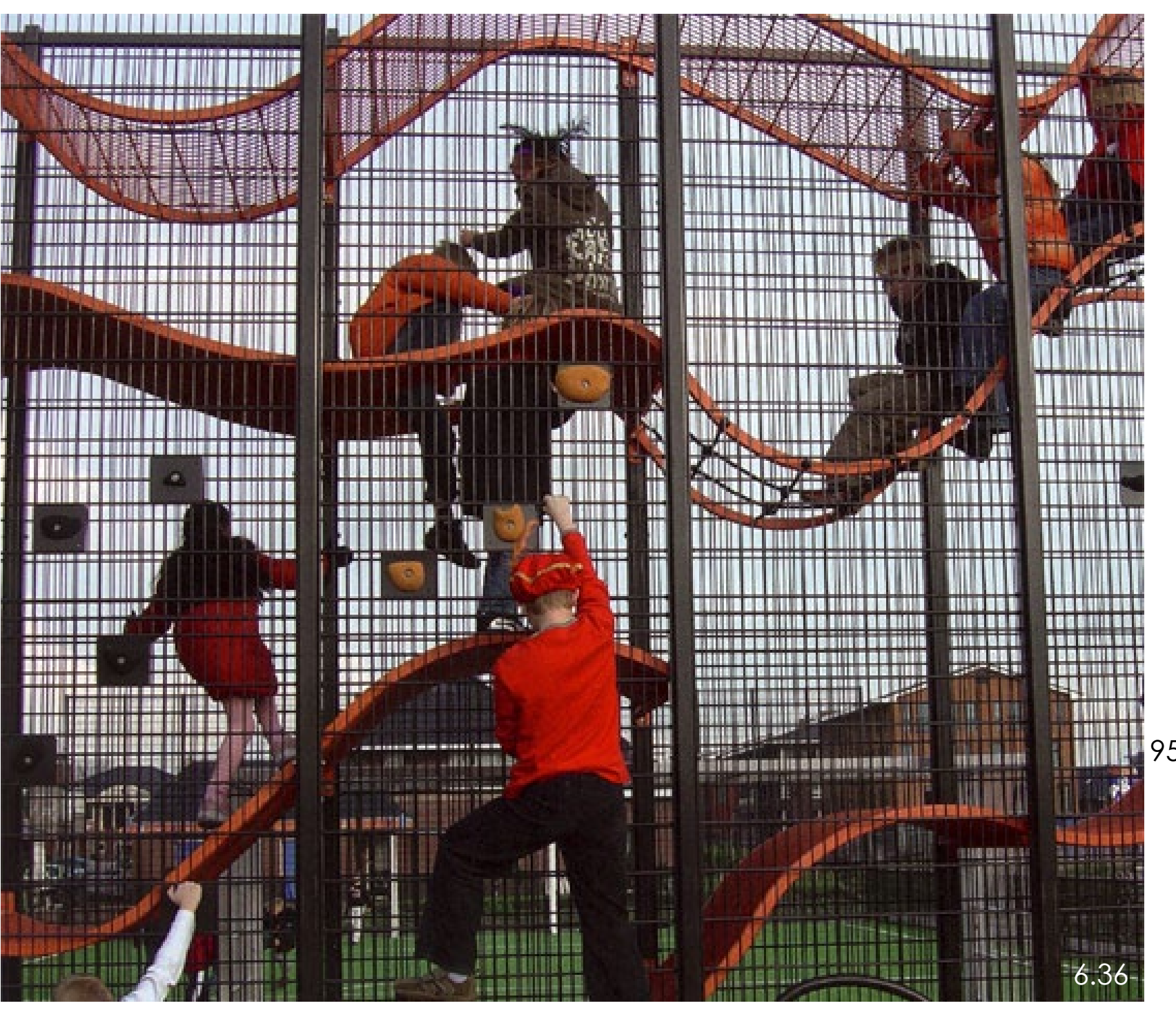

$$
\text { Hititis }
$$
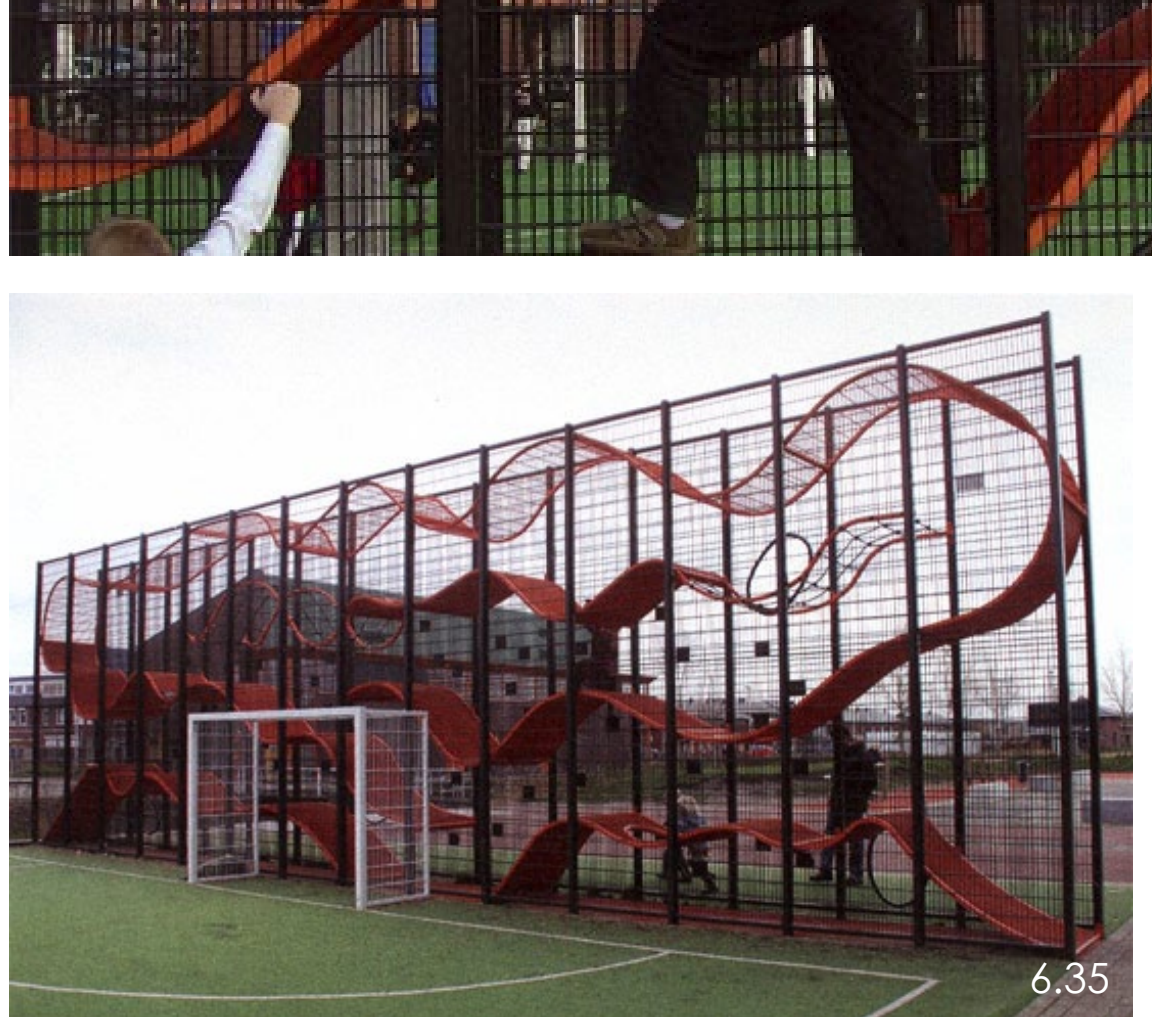
Case Study - Sculptural Playground Wiesbaden, Germany Designed by ANNABAU Architects

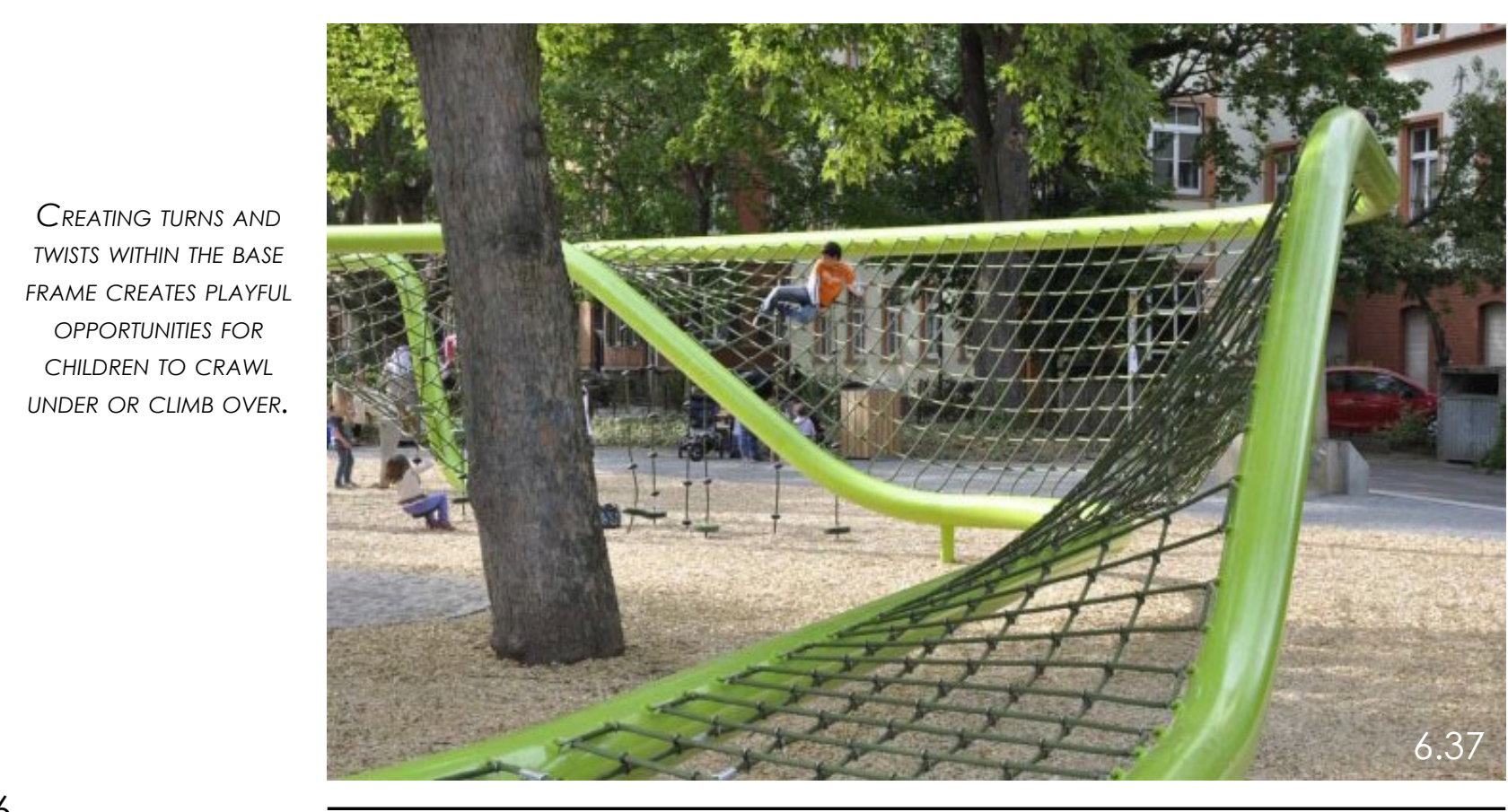

96

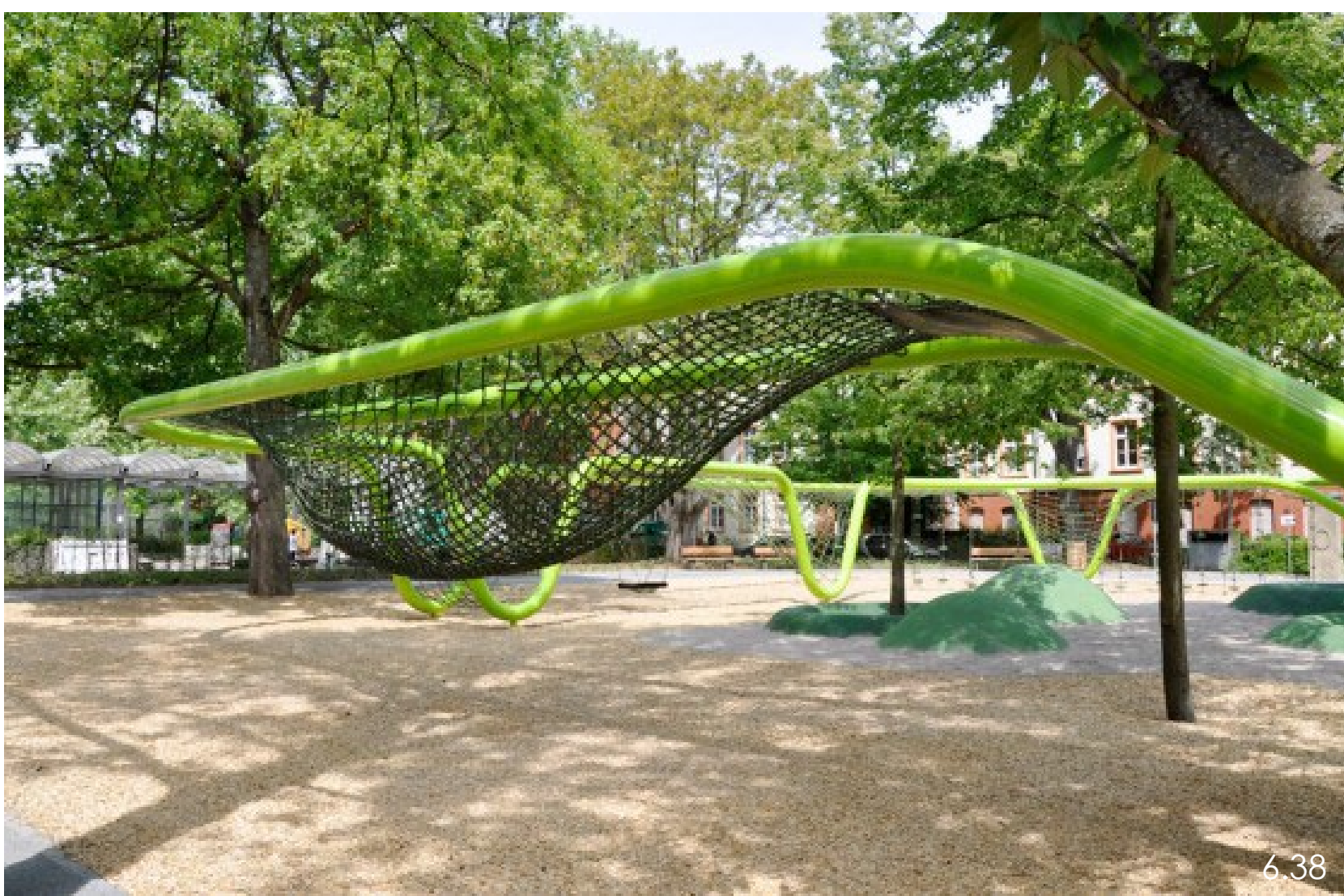
1.3.

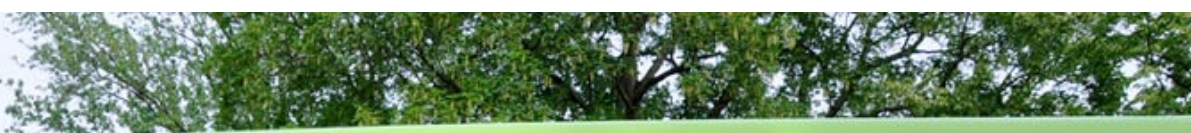
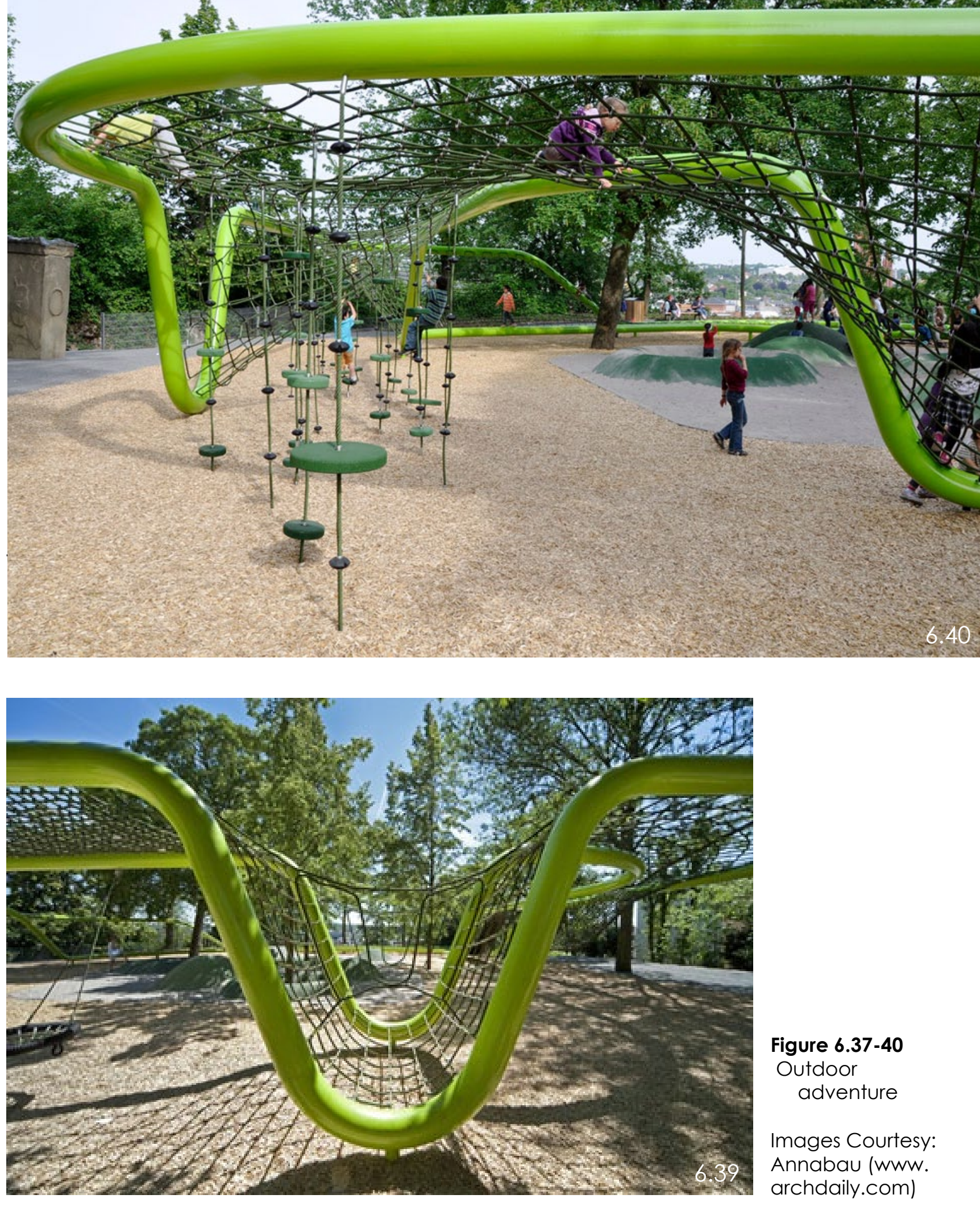
CaseStudy-Morris Arboretum'sTree Adventure Philadelphia, PA

Designed by Metcalfe Architecture and Design

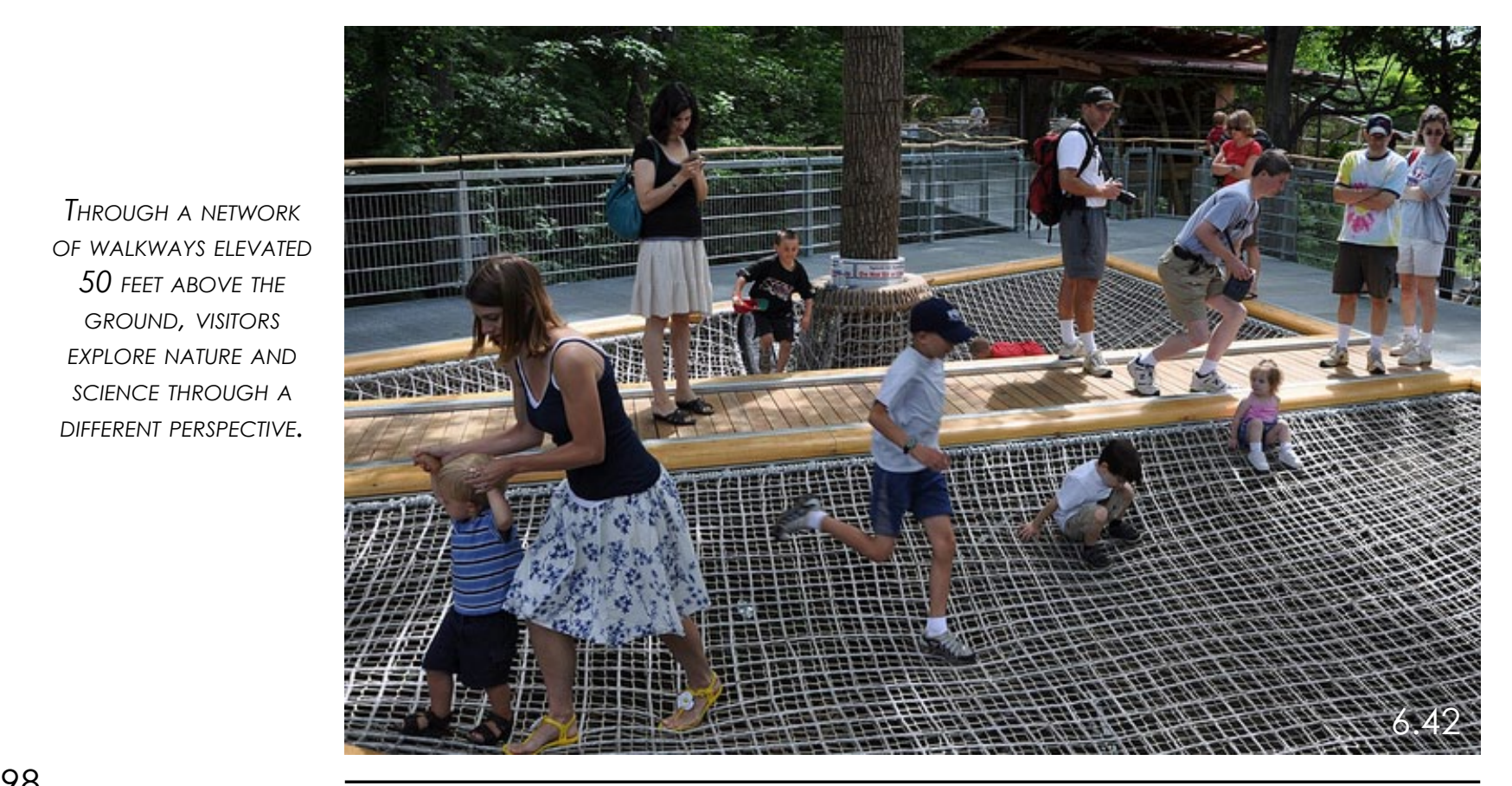

98

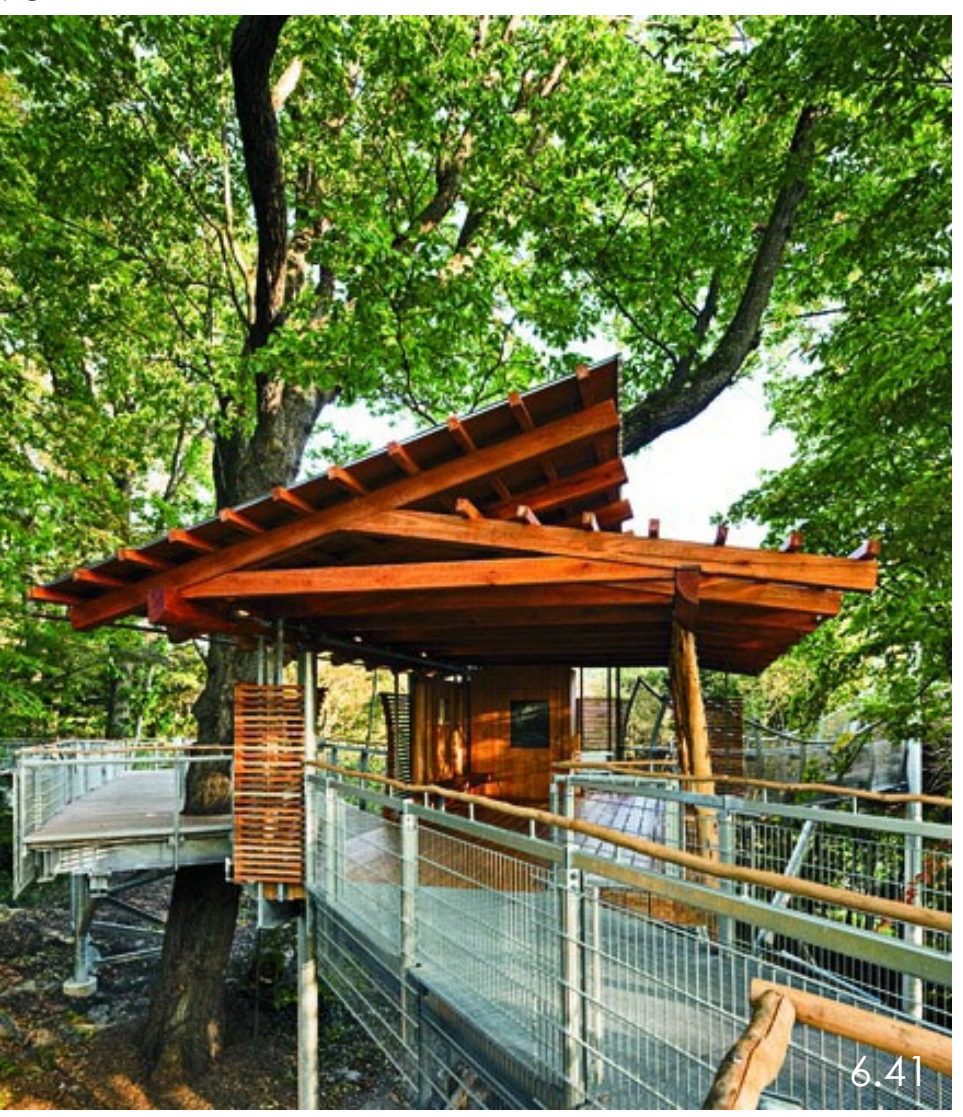

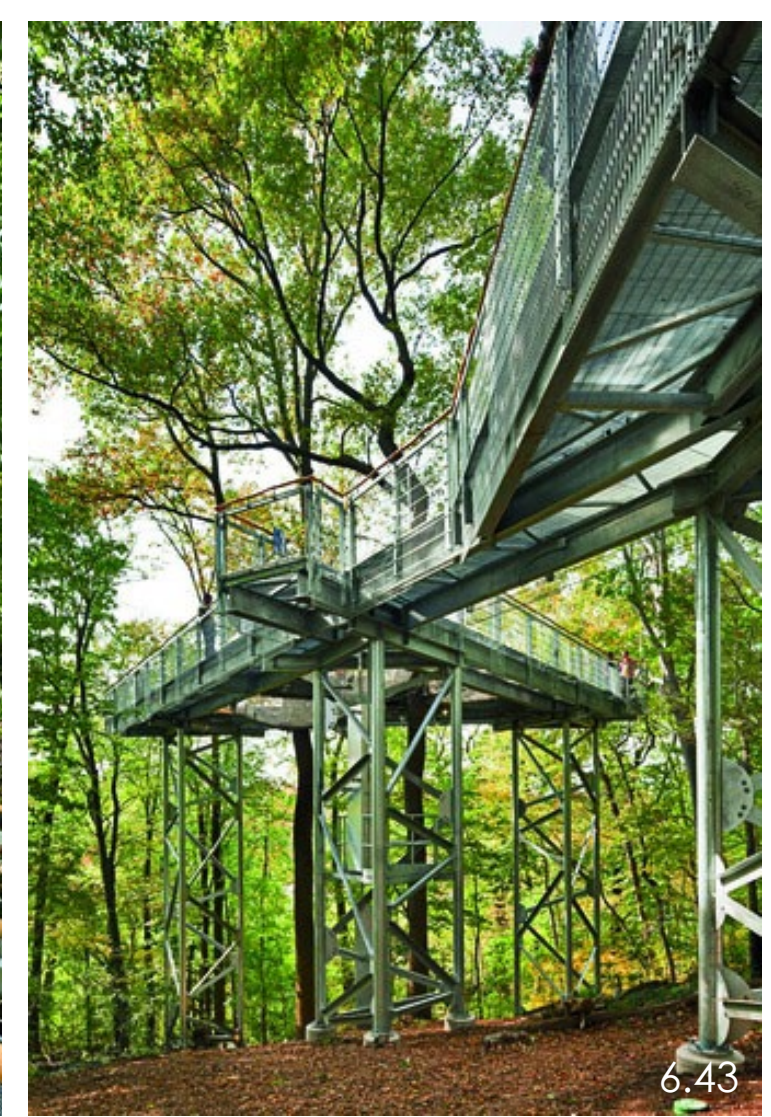
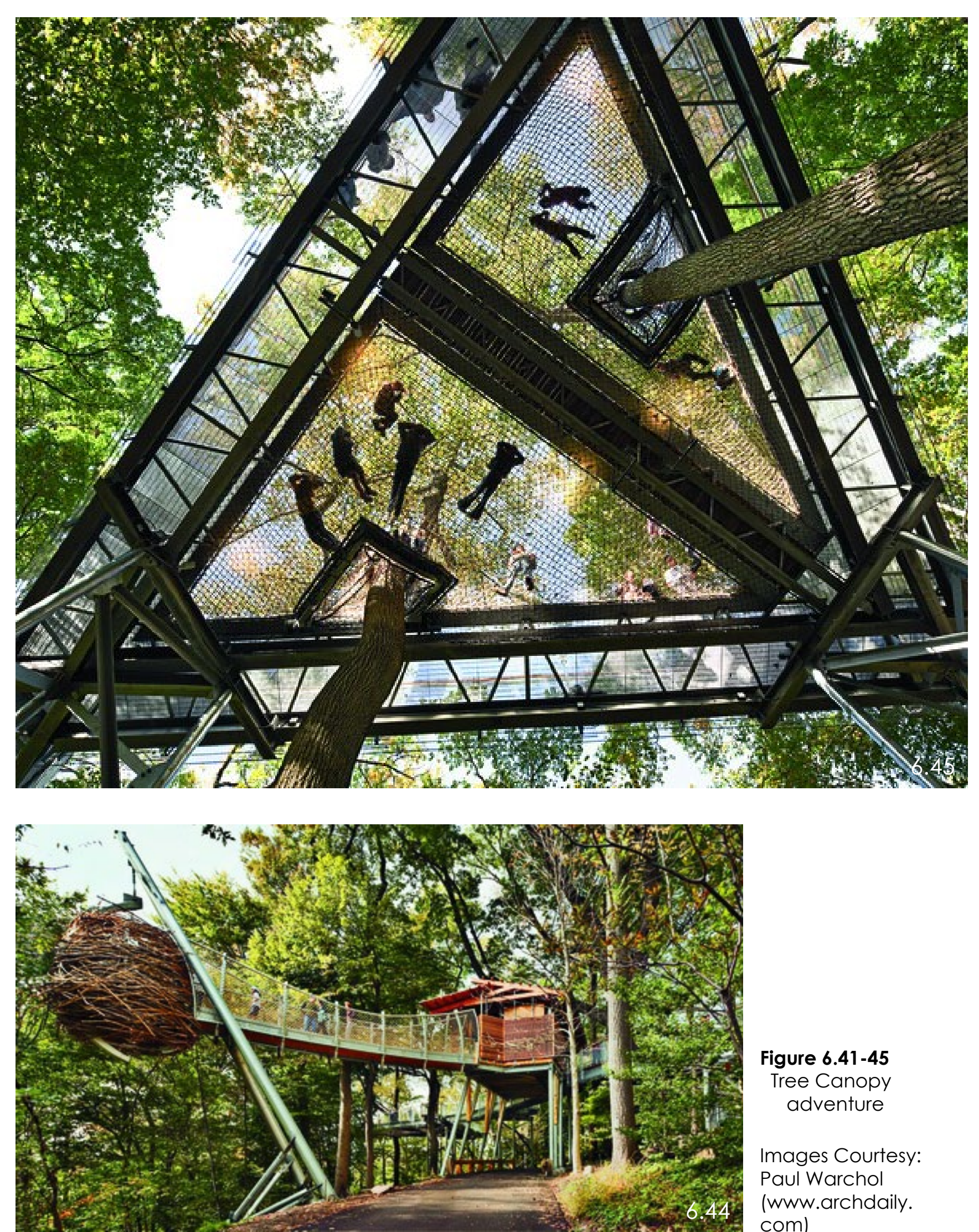

Figure $6.41-45$

adventure

Images Courtesy:

Paul Warchol

www.archdaily

com) 
Case Study - Aarhus Gymnastics \& Motor Skills Hall Aarhus, Denmark

Designed by C. F. Møller Architects
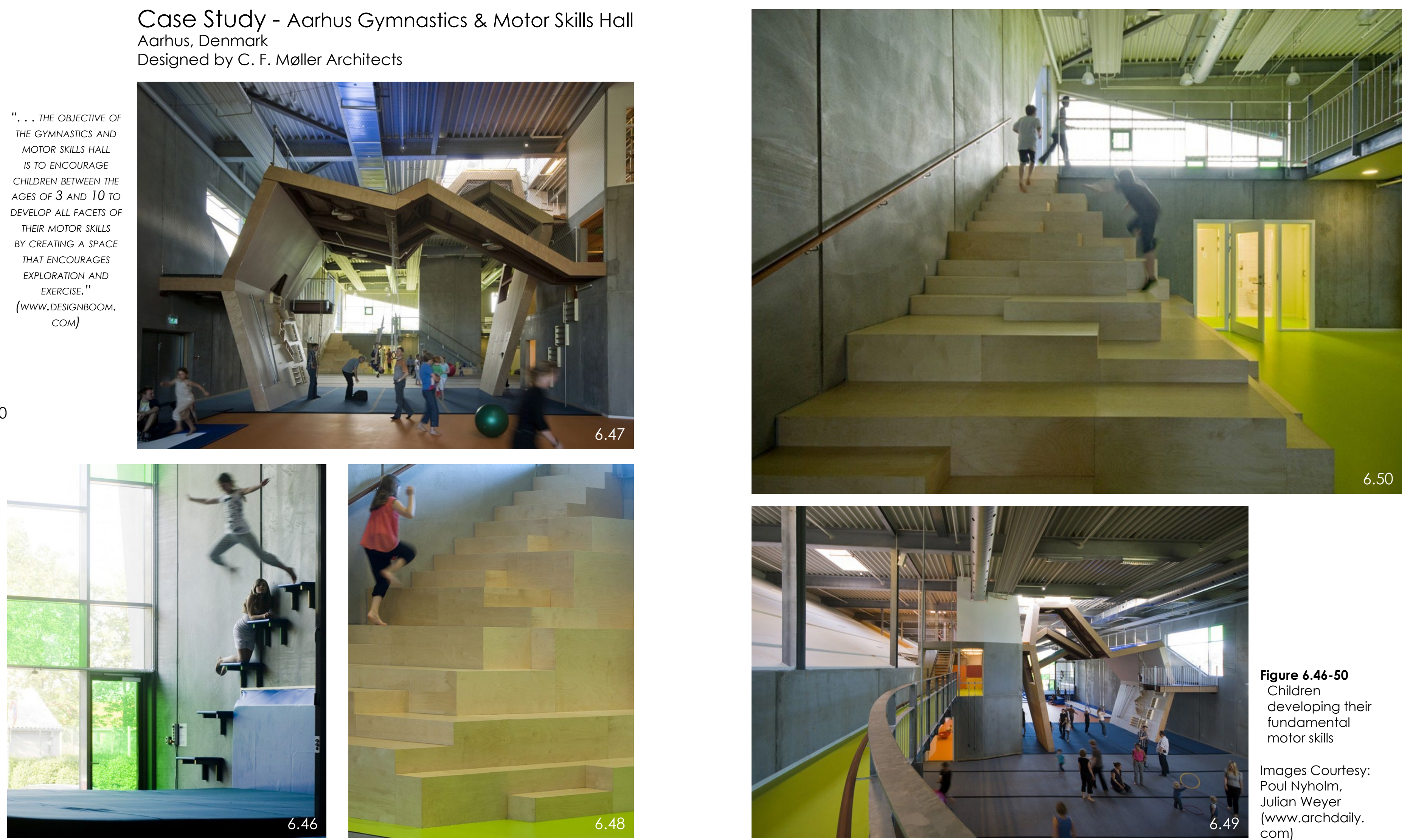

Figure 6.46-50

Children

developing their

fundamental

motor skills

Images Courtesy:

Poul Nyholm,

Julian Weyer

(www.archdaily.

(WWW 
"Alexandria's African American History - Black Education and Parker-Gray School" Page updated Apr 2, 2012 12:41 PM http://alexandriava.gov/
historic/blackhistory/default.aspx?id=37214\#parker. Accessed 10 Sept. 2012

Brown, Stuart. Play: How It Shapes the Brain, Opens the Imagination, and Invigorates the Soul. New York: Penguin Group, 2009. Print.

Center for Disease Control and Prevention, in Children \& Nature Network, Children and Nature 2008: A Report on the Movement to Reconnect Children to the Natural World.

Designed to Move: A Physical Activity Action Agenda. (www.designedtomove. org) Copyright 2012 by Nike, Inc. All rights reserved.

Ewing, R., Brownson, R., \& Berrigan, D. (December 2006) Relationship Between Urban Sprawl and Weight United States Youth. American Journal of Preventive Medicine, Vol 31, No 6. 464-473. Retrieved from www.ajpm-online.net

Freud, Sigmund. Standard Edition of the Completed Psychological Works of Sigmund Freud. Trans. James Strachey. London: Hogarth Press, 1953-74. Print.

Fusco, C. (2007) 'Healthification' and the Promises of Urban Space: A Textual Analysis of Place, Activity, Youth (PLAY-ing) in the City. International

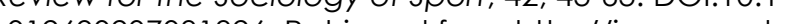
content/abstract/42/1/43

Ginsburg, K. R. (2007) The Importance of Play in Promoting Healthy Child Development and Maintaining Strong Parent-Child Bonds. Pediatrics, 119;182-191. DOI: 10.1542/peds.2006-2697. Retrieved from http://

McKenzie, T. L. \& Kahan, D. (2008) Physical Activity, Public Health, and Elementary Schools. The Elementary School Journal, Vol 108, No 3,
171-180. Retrieved from http://www.jstor.org/stable/10.1086/529100

Quirk, Vanessa. "Forming Playscapes: What Schools Can Learn from Playgrounds" 07 Mar 2012. ArchDaily. http://www.archdailycom/ 214274 /forming-playscapes-what-schools-can-learn-fromplaygrounds/ Accessed 29 May 2013.

Shephard, R. J. and Trudeau, F. (2008) Research on the Outcomes of Elementary School Physical Education. The Elementary School Journa $10.1086 / 529107$

Stine, Sharon. Landscapes for Learning: Creating Outdoor Environments for Children and Youth. New York: John Wiley and Sons, Inc., 1997. Print.

U.S. Department of Education, National Center for Education Statistics, Fast Responce Survery System (FRSS), "Foods and Physical Activity in Public Elementary Schools: 2005," Table 16. FRSS 87, 2005. http://nces.ed.gov/ pubs2006/nutrition/tables/tab16.asp Accessed 9 Sept 2012.

U.S. Department of Education, National Center for Education Statistics (2011). Public Elementary and Secondary School Student Enrollment and Staft Counts from the common core of data: School Year 2009-10. 


\section{BOOKS}

Active Design Guidelines: Promoting Physical Activity and Health in Design. City of New York, 2010. Print.

Armstrong, Thomas. Multiple Intelligences in the Classroom. 3rd ed. Alexandria: ASCD, 2009. Print.

Brown, David R., Gregory W. Heath, and Sarah Levin Martin. Promoting Physical Activity: A Guide for Community Action. 2nd ed. Champaign Human Kinetics, 2009. Print.

Caillois, Roger. Man, Play and Games. Illinois: The Free Press of Glencoe, Inc, 2001. Print.

Danks, Sharon Gamson. Asphalt to Ecosystems: Design Ideas for Schoolyard Transformation. Oakland. CA: New Village Press, 2010. Print.

Brown, Stuart. Play: How It Shapes the Brain, Opens the Imagination, and Invigorates the Soul. New York: Penguin Group, 2009. Print.

Feez, Susan. Montessori and Early Childhood: A Guide for Students. London: SAGE Publications, 2010. Print.

Ford, Alan. Designing the Sustainable School. Australia: The Images Publishing Group, 2007. Print.

Freeman, Claire and Paul Tranter. Children and Their Urban Environment. Washington, DC: Earthscan, 2011. Print.

Gardner. Howard Multiple Intelligences: New Horizons. 2nd ed. New York: Basic Books, 2006. Print.

Gutek, Gerald L. Historical and Philosophical Foundations of Education Upper Saddle River: Prentice-Hall Inc 2001. Print.

Hannaford, Carla. Smart Moves: Why Learning is Not All in Your Head. 2nd ed. Salt Lake City: Great River Books, 2005. Print.

Kohl, Harold W. and Tinker D. Murray. Foundations of Physical Activity and Public Health. Champaign: Human Kinetics, 2012. Print.

Malina, Robert M., Claude Bouchard, and Oded Bar-Or. Growth, Maturation, and Physical Activity. 2nd ed. United States, 2004. Print.

Nair, Prakash and Randal Fielding. The Language of School Design: Design Patterns for 21 st Century Schools. 2nd ed. India: C/S Group, 2007.

OWP/P Architects, VS Furniture, and Bruce Mau Design. The Third Teacher: A collaborative project. China Abrams Books: 2010. Print.
Pellegrini, Anthony D. Recess: Its Role in Education and Development. Mahwah: Lawrence Erlbaum Associates, 2005. Print

Piaget, Jean and Barbel Inhelder. The Child's Conception of Space. New York: W. W. Norton \& Company, Inc., 1967. Print.

Solomon, Susan G. American Playgrounds: Revitalizing Community Spaces. London: University Press of New England, 2005. Print.

Spencer, Christopher and Mark Blades. Children and their Environments: Learning, Using and Designing Spaces. Cambridge: Cambridge University Press, 2006. Print.

Stine, Sharon. Landscapes for Learning: Creating Outdoor Environments for Children and Youth. New York: John Wiley and Sons, Inc., 1997. Print.

Tai, Lolly, Mary Taylor Haque, Gina K McLellan and Erin Jordan Knight. Designing Outdoor Environments for Children. United States: McGrawDesigning Outdoor Environ
Hill Companies, 2006. Print.

Taylor, Anne. Linking Architecture and Education: Sustainable Design for Learning Environments. Albuquerque, University of New Mexico Press: 2009. Print.

Ward, Dianne S., Ruth P. Saunders and Russell R. Pate. Physical Activity Interventions in Children and Adolescents. Champaign: Human Kinetics, 2007. Print.

Center for Disease Control and Prevention, in Children \& Nature Network Children and Nature 2008: A Report on the Movement to Reconnect Children to the Natural World.

Designed to Move: A Physical Activity Action Agenda. (www. designedtomove.org) Copyright 2012 by Nike, Inc. All rights reserved.

Ewing, R., Brownson, R., \& Berrigan, D. (December 2006) Relationship Between Urban Sprawl and Weight United States Youth. American Journal of Preventive Medicine, Vol 31, No 6. 464-473. Retrieved from www.ajpm

Fusco, C. (2007) 'Healthification' and the Promises of Urban Space: A Textual Analysis of Place, Activity, Youth (PLAY-ing) in the City. International
Review for the Sociology of Sport, 42; 43-63. DOl:10.1177/ 1012690207081826 . Retrieved from http://irs.sagepub.com/cgi/ content/abstract/42/1/43

Ginsburg, K. R. (2007) The Importance of Play in Promoting Healthy Child Development and Maintaining Strong Parent-Child Bonds. Pediatrics, 119;182-191. DOI: 10.1542/peds.2006-2697. Retrieved from http:// pediatrics.aapublications.org/content/1 19/1/182.full.html

Gordon, D. (2010) School Health Centers. National Clearinghouse for Educational Facilities at the National Institute of Building Sciences. 
Gorman, N., Lackney, J., Rollings, K., and Huang, T. (2007) Designer Schools: The Role of School Space and Architecture in Obesity Prevention. Obesity

McKenzie, T. L. \& Kahan, D. (2008) Physical Activity, Public Health, and Elementary Schools. The Elementary School Journal, Vol 108, No 3,

orrow, L. M. \& Rand, M. K. (Feb. 1991) Promoting Literacy during Play by Designing Early Childhood Classroom Environments. The Reading stable/20200675

Olrich, T. W. (Sept. 2002) Assessing fundamental motor skills in the elementary school setting: Issues and solutions. Journal of Physical Education Recreation and Dance, Vol. 73, Issue 7.

Pellegrini, A. D., \& Bohn, C. M. (Jan-Feb 2005) The Role of Recess in Children's Cognitive Performance and School Adjustment. Educational Researcher, Vol 34, No 1, 13-19. Retrieved from http://www.jstor.org/ stable/3699908

Shephard, R. J. and Trudeau, F. (2008) Research on the Outcomes of Elementary School Physical Education. The Elementary School Journal or.org/stable/ $10.1086 / 529107$

Staunton, C. E., Hubsmith, D., \& Kallins, W. (Sept 2003) Promoting Safe Walking and Biking to School: The Marin County Success Story. American Journal of Public Health, Vol 93, No 9, 1431-1434.

Thomas, K. T. \& Thomas, J. R. (January 2008) Principles of Motor Developmen for Elementary School Physical Education. The Elementary School Journal, vol 108, No. 3 181-195. Retrieved from http://www.jstor.org/ stable/10.1086/529101

U.S. Department of Education, National Center for Education Statistics, Fast Responce Survery System (FRSS), "Foods and Physical Activity in Public Elementary Schools: 2005," FRSS 87, 2005.

U.S. Department of Education, National Center for Education Statistics (2011). Public Elementary and Secondary School Student Enrollment and Staff Counts from the common core of data: School Year 2009-10.

U.S. Department of Education, National Center for Education Statistics, Fast Responce Survery System (FRSS), "Foods and Physical Activity in Public Elementary Schools: 2005," FRSS 87, 2005.

Zimring, C., Joseph, A., Nicoll, G., \& Tsepas, S. (2005) Influences of Building Design and Site Design on Physical Activity. American Journal of Preventive Medicine. Vol 28, No 2S2, 186-193.

WEBSITES

Architects of Achievements. http://www.archachieve.net/index.html Accessed 5 Oct. 2012
Active Living Research. http://www.activelivingresearch.org/ Accessed 8 Dec. 2012

CDC - Center for Disease Control and Prevention. http://www.cdc.gov/ Accessed 1 Sept. 2012

CDC - Division of Nutrition, Physical Activity and Obesity (DNPAO)

http://www.cdc.gov/nccdphp/dnpao/index.html Accessed 3 Sept. 2012

CDC - National Center for Chronic Disease Prevention \& Health Promotion http://www.cdc.gov/chronicdisease/index.htm Accessed 3 Sept. 2012

City of Alexandria, VA. http://alexandriava.gov Accessed 10 Sept. 2012

Council of Educational Facility Planners International. http://www.cefpi.org/ Accessed 15 Oct. 2012

Design Share: Designing for the future or learning. http://www.designshare.com/ Accessed 25 Sept. 2012

Designed to Move. http://designedtomove.org/ Accessed 20 Nov. 2012

Edutopia: What works in Education. http://www.edutopia.org/ Accessed 10 Sept. 2012

Healthy School Campaign. http://www.healthyschoolscampaign.org/ Accessed 13 Oct. 2012

KaBoom! It starts with a playground. http://kaboom.org/ Accessed 6 Nov. 2012

Let's Give Them a Shot. http://letsgivethemashot.org Accessed 13 Nov. 2012

Let's Move Campaign. http://www.letsmove.gov/ Accessed 4 Sept. 2012

National Association for Sports and Physical Education. http://www. aahperd.org/naspe/ Accessed 10 Sept. 2012

National Center for Safe Routes to School. http://www.walkbiketoschool.org/ Accessed 12 Oct. 2012

National Center for Educational Statistics. http://nces.ed.gov/ Accessed 18 Sept. 2012

National Clearinghouse for Educational Facilities. http://www.ncef.org/ Accessed 22 Sept. 2012

Natural Learning Initiative - NC State University. http://naturalearning.org/Accessed 2 Nov. 2012

Play-Scapes: All the best playgrounds are here. http://www.play-scapes.com/ Accessed 18 Nov. 2012

Sports, Play, and Active Recreation for Kids (SPARK). http://www.sparkpe.org Accessed 6 Sept. 2012

Walking School Bus. http://www.walkingschoolbus.org/Accessed 10 Sept. 2012

World Health Organization. http://www who.int/en/Accessed 19 Sept. 2012 
Paul, Paul and Susan (my committee members), thank you for your support and extra push along the way to develop my thesis to my best potential. I would not have explored as many ideas and iterations without your encouragement.

Thank you to Arlington County Public Schools, Alexandria City Public Schools, KaBoom, and Designed to Move for you willingness to provided unlimited resources and information as I began my thesis research.

WAAC classmates and faculty, thank you for all the support along this journey. Each and everyone of you helped me towards a successful defense and completion of my masters.

Mom, Dad, Christina, and Ellen, thank you for being only a phone call away. You all are and will continue to be an inspiration to me.

Brett, thank you for your guidance and wisdom over the past year. I only hope that as we continue to grow as young architects our love for architecture

and design will grow together. 